University of Louisville

ThinkIR: The University of Louisville's Institutional Repository

Electronic Theses and Dissertations

1947

\title{
Temperature relationships in tent structures.
}

Earl Robert Gerhard 1922-

University of Louisville

Follow this and additional works at: https://ir.library.louisville.edu/etd

Part of the Mechanical Engineering Commons

\section{Recommended Citation}

Gerhard, Earl Robert 1922-, "Temperature relationships in tent structures." (1947). Electronic Theses and Dissertations. Paper 2041.

https://doi.org/10.18297/etd/2041

This Master's Thesis is brought to you for free and open access by ThinkIR: The University of Louisville's Institutional Repository. It has been accepted for inclusion in Electronic Theses and Dissertations by an authorized administrator of ThinkIR: The University of Louisville's Institutional Repository. This title appears here courtesy of the author, who has retained all other copyrights. For more information, please contact thinkir@louisville.edu. 


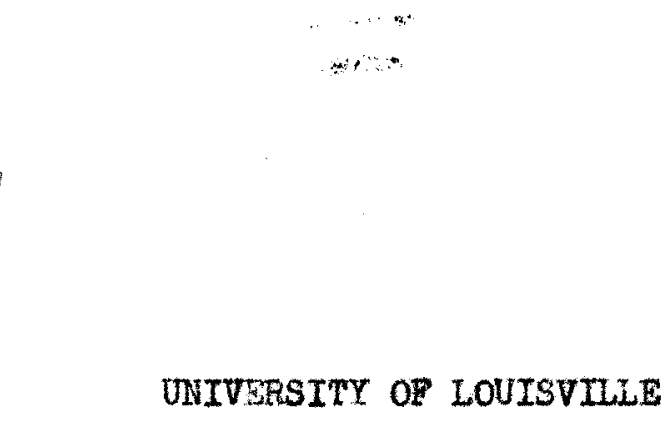

UNIVERSTTY OP LOUISVILLE

TEMPERATURE RELATIONSHIPS IN TSNT STRUCTURES

\author{
A Thesis \\ Submitted to the Faoulty \\ of the Graduate Sohool \\ of the Iniversity of Louisville \\ in Partial Fulfilment \\ of the Requirements \\ for the Degree of
}

MASTER ON CHEMTCAL BNGINEERING

Departroent of Chemical Bnglneering

Barl R. Gerhard

December, 1947 
TYMPEATUPE RELATIONSHIPS IN TRNT STRUCTURS

Earl R. Gerhard

Approved by the Examining Committee.

Director $\frac{\text { W. R. Barnes }}{\text { R. C. Ernst }}$

December, 1947 
ACKNOWLEDGUENT

The author wishes to ecknowledge

the kind assiatance and helpful guidance

of Dr. R. C. Ernst

and Ur. W. R. Barnes

who directed this rasearch 
CONTENTS

Page

Aclonowledgment. .......................... 111

list of Tablos. ................................ v List of Migures ............................ v1 Abstract. ............................... v11 Introduction. ............................ 1 Hitorical. ............................. 4 Theoretical ............................ 7

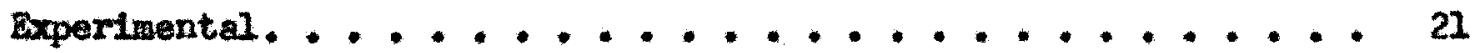

1. Temperature Control in Tents - Winter Phase........ 22

2. Temperature Control in Tents - Sumner Phase........ 57

3. Aretio Shelter Design. ................. 62 Sumary and Conclusions .................... 72 Iltereture Cited. ..................... 77

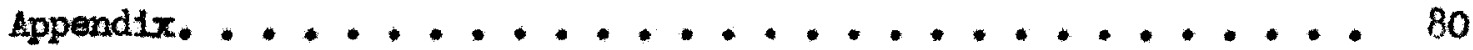

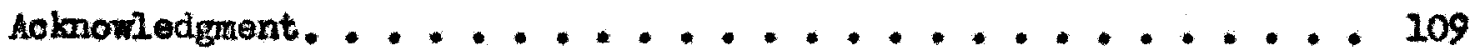
Vita. ................................ 111 
Page

Table 1 Average Heat Loss Coefficients. . . . . . . . . . 37

Table 2 height and Bulk of Liners............... 52

Table 3 List of Test Euns - Type and weather. . . . . . . . 88

Table 4 Air, Ground, and Fabric Temperature . .......... 91

Table 5 Temperature Dlfferences ..................... 93

Table 6 Overall and Individual Coefficlents of Heat Transfer. . . 95

Table 7 confort Index . . . . . . . . . . . . . . 98

Table 8 Fuel Consurption and Savings wth Large Wall Tent. . . 100

Table 9 Cost, melght, Bulk sumary for one Month's Operetion. . 101

Table 10 Tent Temperature Data - Large Hooded Fles. . . . . 102

Table 11 Average Temperatures - Tents Closed ......... 106

Table 12 Average Temperatures - Tents Open ............ 107

Table 13 Temperature Differences - Hooded Fles.......... 108 


\section{LIST OF FIGURES}

Page

Fig. 1 Location of Mesuring Equipment in Temperature Control Tent. 24

Fig. 2 Inside Air Temperature Versus Mime of Day. . . . . . . . 26

PIg. 3 Inside Alr Temperature Versus Cumulative Voluna. . . . . . 29

FIg. 4 Liner Temperature Versus Time of Day . . . . . . . . . 30

Fig. 5 Tent Fabric Temperature Versus Time of Day . . . . . . . 31

Fig. 6 Temperatire Versus Mine of Day ................. 33

Mg. 7 Alr Temperature Distribution Inside Tents........... 34

Pg. 8 Tent Comfort Index Versus Heat Input ............. 39

F1g. 9 Nomogran for the Determination of Comfort Heating Condition. 40

Flg. 10 Heat Invut from Sun Versus Time of Day . . . . . . . . 47

Fig. II Temperature Difference Versus Heat Input .......... 50

Flg. 12 Cost - Bulk - Weight of Liner and Fuel . . . . . . . . 55

FIg. 13 Detall of Large Hooded $\mathrm{Fy} \ldots \ldots$

Fig. I4 Tne Versus A1r and Surface Teaperature for Large Hooded MIes............................ 61

Fig. 15 Arctic Shelter Frane Draring No.1.............663

FIg. 16 Aretio Shelter Frane Drawing No. $2, \ldots \ldots$.......... 64

Fig. 17 Arctic Shelter Frame Drawing No. $3 \ldots \ldots \ldots$

Flg. 18 Arotic Shelter Frame Draring No. $4, \ldots \ldots 6$

Plg. 19 Arctic Shelter Frame Jrawng Mo.5. . ........ 67

Fig. 20 Arctic Shelter Frame Drawing No.6............. 68

Flg. 21 Arctic Shelter Prane Drawing No. 7 ............ 69

Flg. 22 Semple Data Sheet. ........................ 87 
ABSTRACT 
This thesis on the temperature relationships in tent structures consista of three parts: (1) Temperature Control in Tents - Winter Phase; (2) Temperature Control in Tents - Sumer Phases and (3) Arctic Shelter Design.

A theory of heat transfer into and from tents was dereloped and applied to the experinental data. In the rinter phase a study wes made of large mall tents and squad tents using as insulators, liners of 4 ox. white cottion, 8 oz. 0.D. 7 cotton and one-half inch thick flberglas quiltod between two layers of $4 \mathrm{oz}$. white cotton. Measurements were made of air and fabric terperatures over a range of westher conditions wth a lonown heat imput to the tents. overall heat transfer coefficients were calculated for a comperison of the insulating value of the several liners. The effectIveness of the liners elso wa indieated by a comfort index for each tent and Iiner combination. Another comparison was made on the basis of weight, bulk, and fuel savings.

In the sumper phase work a study was rade of the effect of hooded flles on the comfort conditions wthin tents, These hooded flies completely shaded the tent from direct solar radiation. Flles of single and double layers of fabrics were used and conclusions reached as to the best method of reducing temperetures within tents.

The design modifleations of a vehicle-portable arotic shelter frame are presented, the changes resulting from studies and tests conducted by the Army in the Arctic during the winter of 1946. 
INTRODUCTION 


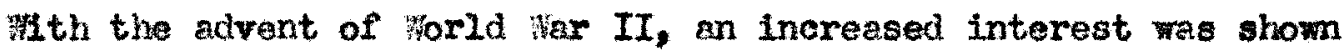
in the living conditions of soldiers. Since the majority of troop maneuvers did not perait the construction of permenent shelters, the use of tents, especielly in overseas areas, becane an important consideration. The use of existing tents in tropical and neer arctic operations brought out the many deficiencies in the types of tentage then avallable. AccordIngly, a series of research stations were established by the offles of the Quartermaster cenaral to improve the tents and tentage naterials for military use. One phase of the research was the study of temperature control in tents, and research on this phase was begun at the ontversity of Loutaville Institute of Industrial Fesearch in 1945. This thesis is a presentation of the data and results obtained in 1947 on temperature control in tents for both sumer and wintor phases, and the design of a vehicle-portable arctio shelter.

During the winter, in moderete or cold climates, considerable heat must be supplied to maintein comfortable conditions in tents and it is necessary to use Insulation in addition to that of the tent fabric to keep the fuel consumption to a low value. For this investigation it was considered destrable to use liners to reduce heat loss and to study the effectiveness of Iiners of different size, shape, and materials of construction. In addition, a study of the effect of wind, relative humidity, ground, and air temperatures on the heat transfer of varlous tent-1iner combinations was necessary.

In sumer weather, exposed tent fabrics absorb sufficient solar radiation to ralse the fabric temperature and the inside air temperature considerably above amblent if temperature. This temperature rise produces uncomfortable and frequently unendurable conditions within a elosed tent, 
and even en open tent may be far from confortable because of radiation from the tent fabric to the occupant.

Preliminary investigations were undertaken of the use of flies to shade the tent deck from direct solar radiation, thereby reducing the Inside air and fabric tenperatures and tending to make the tent nore confortable. These results indleated the need for additional studies with flles of spectal design.

The extremes of both sumer and rinter tentage problems are encountered in the Arctic where satisfactory large tent structures for winter use are nonexistert. The necessity for an 2l1-purpose vehicleportable arctio shelter led to the design of an alminum, arched-rib frame to be covered with an inswlating fabric. The uneven terrain upon which this shelter would be erected prompted the design of rldged floor beens and ribs. For ease of erection and expansion a sectional type unit, capable of easy assembly under adverse weather conditions, was favored. Although overell dimensions, structure type, and meterials of construction were dictated by the housing function to be served by this tent, the perfection or alteration of many details was desirable in order to correct inadequactes of the ortginal design. 
IISTORTCAL 
From the time of primitive man, tents had been used as shelters by nomadic tribes. Later tents became the main housing for mobile army unfts. During these many conturfes, the structural properties of tents essentially remeined the same. Soon after the beginning of Horld War II the necessity of more suitable tent structures led to the establishment of research stations to investigate the problen of improvod tent design. One phese of this study was the teaperature relationships in tent structures. The imediate problen was to determine the best nethods of making the existing arry tentage comfortable in both cold and warn clinates. Results of laboratory and field tests conduoted betwen Januery 1945 and June 1946 on temperature control in tents are presented in an 18 month report on "Improved Design of Tents and Tentage Matarlal ".(1) Included in this report are the results of field tests on sumer phase temperature control in tents and laboratory studies of the radiation and convection properties of fabrics. The use of a fly in preforence to a liner, and the use of a fabric of high reflectivity and low emissivity are recommended for summer phese temereture control.

Further studies on sumer phase temperature control and many of the data in this thesis are presented in a report from the Iniversity of Loulsville Institute of Industrial Research on Temperature Control Studies covering the period from June 1, 1946, to June 1, 1947. Other Iiterature on the subject of temperature control in tents is to be found in the textile reports from the office of the Quarternaster General.(2) However, no literature has been located on Hinter studies of cottion liners al though liners periodically have been used for many years in cold climate tentage. indle comparstively little was known of the value of insulation in tents, much work has been done on insulation and heet loss in other 
flelds. A study of the heating analysis of plywood panels as made by Haber and Hutchinson in their book "Panel Heating and Cooling fnalysis"(3) was useful in this study as well as ldeas obtained from the American Institute of Feating and Ventllating anginears (A.Y.H.V.E*) publications. Prior to Forld War II, arny untts were housed in efther temporary shelters (tents) or permenent solld foundation buildings when time and conditions permitted their erection. However, during this war a vehicle-porteble shelter capable of serving in the nore adverse weather conditions of the Arctic wes found desireble. Accordingly, in June 19L6, the design of such a unit wes undertaken at the iniversity of Louisville Institute of Industrial Research. (4) The orletnal plans of this unit called for an alunimm frane covered with fabric-insulation system and although the basto unit remained the same, the many nodifioations and alterations of detejis did not permit the completion of the design until recentiy. 
THEORETICAL 
WINTER PHASE CONSIDERATIOHS

The standerd arry tent is constructed of 12.29 oz. cotton duck. It is woven into panels 36 inches wide and aproximetely 0.03 inches thick. The length of these panels depands upon the size and shepe of the particular type of tent strueture in which they are used. The fabric is supported by wooden poles in the center and at the corners of the tent structure by ropes attached to pegs in the ground. The fabric panels aro sewn together at the seams and laced together at the corners and end openings.

when the air inside a tent is heated, it increases in temperature, and, Its increased heat content is given by $c_{p}\left(t_{2}-t_{1}\right)$, where

Y = weight of the mass of air

$c_{p}=$ specific heat of air

$t_{2}=$ final air temperature

$t_{1}=$ initial air termerature.

This air loses heat by convection to the inside surface of the liner, by conduction through the liner and by radiation and convection to the tent fabric. Finaly, this heat is lost from the outside surface of the tent by convection to the ambient alr and radiation to the surroundings. During the heating period

$$
\left(\frac{d Q}{d \theta}\right)_{\text {reaters }}=c_{p} w \frac{d t}{d \theta}+\left(\frac{d Q t}{d \theta}\right)_{\text {Loss }}
$$

where,

$$
\begin{aligned}
& \frac{d Q}{d \theta}=\text { heat flow }(Q) \text { per unit time }(\theta) \\
& \frac{d t}{d \theta}=\text { change of air temperature }(t) \text { with time }(\theta)
\end{aligned}
$$


and

$$
\left(\frac{d Q}{d \theta}\right)_{\text {LOSg }}=U A \Delta t
$$

where

$$
\begin{aligned}
& U=\text { overall coefficient of heat transfer } \\
& A=\text { area } \\
& \Delta t=\text { temperature difference between the contents of the } \\
& \text { tent and the outstde surroundings. }
\end{aligned}
$$

When equilibrium has been obtalned wh constant heat inout and unidirectional heat flow, $c_{p} \frac{d t}{d \theta}$ becomes 0 and,

$$
q_{\text {heater }}=U A \Delta t
$$

where

$q=$ the heat transferred per unit time.

The heat input from the heaters ultimetely can be lost by concuction through the ground and by convection and radiation fron the outside tent surface. If the heat loss by conduction through the ground is considered negligible, the terms of equation (3) becone:

A area of outside tent surface

$\Delta t=$ temperature inside alr minus temperature outside air

$\mathrm{y}=$ overall coefficient of hoat loss.

The inside alr temperature is an average or bulk temperature of air Inside the tent since this air temperature varies with 1 ts proximity to the heater and its helght above the floor.

It is noted that the above $\Delta t$ can be used only if the tent is losing hest by radiation to surroundings at the same tenperature as the ambient air. Actually, the tent is ultimately radiating to interstellar 
space on clear nights, but on overoast deys or nights it is rediating to surroundings which are approximately the temperature of the nearby buildings, ground, trees, etc. When the temperature of these surroundings differs appreciably from the amblent air, an equivalent outside atr temperature may be calculated depending on the relative amounts of heat lost by radiation and convection.

In alwilar menner the individuel or equivalent film coefficlent of heat loss from any surface for untdirectional heat flow at equilibrium 1s:

$$
\mathrm{q}_{\text {heater }}=\mathrm{h} A \Delta \mathrm{t}
$$

where

$$
\begin{aligned}
& \mathrm{h}=\text { the individuel coefficient of heat loss } \\
& \Delta t=\text { the temperature difference betwen the surfece and the } \\
& \text { adjacent air. }
\end{aligned}
$$

This equivalent film coefficient, $h$, can be considered to consist of two parts, $h_{c}$ and $h_{r}$, where $h_{c}$ refers to an equivalent film coefficient for comvection and $h_{r}$ refers to an equivalent $f 1$ lm coeffictent for radiation, and

$$
q=\left(h_{c}+h_{r}\right) A \Delta t=h_{e} A \Delta t_{1}+h_{r} A \Delta t_{2}
$$

The quantity of heat lost by radiation $\left(q_{r}\right)$ is

$$
q_{r}=0.173 \AA\left[\left(\frac{T_{1}}{100}\right)^{4}-\left(\frac{T_{2}}{100}\right)^{4}\right] F_{A} F_{E}
$$

where

$$
\begin{aligned}
& T_{1}=\text { temperature of radiation surface } \\
& T_{2}=\text { temperature of receiving surface } \\
& A=\text { area of radiating surface } \\
& F_{A}=\text { emissivity factor }
\end{aligned}
$$


$F_{\mathrm{E}}=$ enissivity factor.

If we consider the tent as a completely enclosed body, small compared to the enclosing body, $F_{A}=1$ and $F_{E}=o_{1}$, where $a_{1}$ is the enissivity of the radiating surface. Therefore

$$
q_{r}=0.173 A_{1}\left[\left(\frac{T_{1}}{100}\right)^{4}-\left(\frac{T_{2}}{100}\right)^{4}\right] o_{1}=h_{r} A_{1}\left(t_{1}-t_{2}\right)
$$

and

$$
h_{T}=\frac{0.173 e_{1}\left[\left(\frac{T_{1}}{100}\right)^{4}-\left(\frac{T_{2}}{100}\right)^{4}\right]}{T_{1}-T_{2}}
$$

Laboratory studies showed the emissivity of $12.29 \mathrm{oz}$. duck with a JQD 242 finish to be $0.92 .(5)$ (JQD 242 is the Jeffersonville quartermaster Depot designation for a type of water repellant, flame and fire resistant fabric finish.) Therefore, for a temperature difference of $50-60^{\circ} \mathrm{F} ., \mathrm{h}_{\mathrm{r}}$ is approximetely $1 \mathrm{BTU} /(\mathrm{Fr}$.$) (sq. ft.) \left({ }^{\circ} \mathrm{F}\right)$.

The heat loss by convection from a fabric to air is a function of the relative humidity of the air and the velocity of the air past the surface, the latter being the controlining factor. Laboratory studies of fabrics, Including $12.29 \mathrm{oz}$. duck, showed that $h_{c}=7^{6}$ for a range of velocities, $\nabla$, from 2 to $10 \mathrm{mph}$. (6) For wind velocities of 3 to 4 mph a value of $h_{c}=2 \mathrm{BTU} /(\mathrm{Fr}$.$\left.) (sq. ft. \right)\left({ }^{\circ} \mathrm{F}\right)$ could be used. Therefore, when the wind velocity is 3 to 4 aph and the temperature difference between the tent deck and the surroundings to which it is radiating is between 50 and $60^{\circ} \mathrm{F}$, the value of $h_{c}$ is approximately equal to twice the value of $h_{x}$ and the following relationship may be developed:

$$
q=q_{r}+q_{c}=h_{C} A\left(t_{D}-t_{a}\right)+h_{r} A\left(t_{D}-t_{b}\right)
$$


where

$$
\begin{aligned}
& a_{I}=\text { heat lost by radiation } \\
& q_{c}=\text { heat lost by comrection } \\
& t_{a}=\text { temperature of air } \\
& t_{b}=\text { temperature of surroundings } \\
& t_{D}=\text { temperature of tent surface }
\end{aligned}
$$

but

$$
h=h_{c}+b_{x}=3 h_{x}
$$

Then

$$
\begin{aligned}
& q=2 h_{r} A\left(t_{D}-t_{a}\right)+h_{F} A\left(t_{D}-t_{b}\right) \\
& q=h_{P} A\left(2 t_{D}-2 t_{D}+t_{D}-t_{b}\right) \\
& q=h A\left[t_{D}-\left(2 t_{a} / 3+t_{D} / 3\right)\right]=h A\left(t_{D}-t_{a b}\right)
\end{aligned}
$$

where

$$
t_{a b}=2 t_{a} / 3+t_{b} / 3
$$

and is considered as an equivalent air tenverature.

In other words an oquivalent air temprature equal to two-thirds of the outside air temperature and one-third of the surrounding temperature showl be used when the temperature of the alr and surroundings differ appreciably.

In the previous derivations the heat fron the heaters was considered to be the only heat input into the tent. However, during the day an additional quantity of heat, $q_{8}$, is supplied to the tent by rediation from the sky. On a clear, sunny day this amount to a large portion of the total beat Input, while on overcast days and nights the sky radiation is amall, being at a mininum between midnight and 2:00 A.M. By use of a pyrhellometer the intensity of solar rediation could be measured. Thts intensity of solar radiation conbined with the air film coefficient and 
absorptivity of the surface could be included in a factor which when added to the air temperature would give sol-air temperature equivalent to an air temprature alone that would give the same heat loss characteristics to the tent. (7) That is,

$$
t_{e}=t_{a}+\frac{I \propto}{h}
$$

where

$$
\begin{aligned}
& t_{e}=\text { sol-air temperature } \\
& I=\text { intensity of radiation } \\
& \alpha=\text { absorptivity of tent surface } \\
& h=\text { outside surface film coefflcient. }
\end{aligned}
$$

The heat input into the tent from solar radiation is a function of the transmissivity, $\mathbb{F}_{t}$, reflectivity, $F_{r}$, and absorptivity, $F_{a}$, of the fabric which acts as a radiation interceptor. Hence whit liner which has a high reflectivity will aot as further barrier to radiation. In defining the terms in equation (3) it was assumed that the heat loss to the ground was negligible. The loss of heat into the ground is a function of the surface fIIm and conductivity of the ground, the temperature difference between the air and the ground, and the ratio of the floor area to the tent area. During the winter inonths heat flows frois the interior of the earth to the surface and then to the surrounding air. Hence, heat conducted into the ground from the tent would be a somewhat complicated function of the type of soil, air and ground temperatures, time of exposure, variation in solar radiation, etc. Although studies of heat losses from basenents have show values of $6-8$ BTU/(Fr) (sq. ft.) ( ${ }^{\circ} \mathrm{F} /$ In.) for a heavy clay soil, $(8)$ some purely qualitative experiments with varying thickness of floor insulation indicated negligible losses into the ground. 
A fundamental part of temperature control is the problem of controlling conditions to the "comfort zane".(9) The comfort sone is a range of eir temperatures roughly bounded by the extrenes of $700^{\circ} \pm 10$ degres, In which the person feels the same degree of confort as experienced when the tomperature of the air and surrounding surfaces are at $70^{\circ} \mathrm{F}$ and the reletive humidity is 50 per cont.

The establishent of comfort conditions depends primerily on the ma1ntenance of an environment in with the body can lose heat at a rate equal to that of its production; and this without need of such extrone physiologleal adjustments as evaporative regulation or shivering. The question arises that if comfort conditions exist at one teraperature, is it possible to maintain comfort at other temperatures. To answer this question and to define the confort renge it is necssary first to analyze the heat losses of the body.

A normal person, seated and at rest, dissipates heat at a rate of approximately 400 BTU/hr. under standard conditions of light clothing and in air at about $70^{\circ} \mathrm{F}$, and 50 per cent relative humidity. Evaporative heat losses amount to approximately 25 per cent of the total, or 100 BTU/hr. Radiation and convection heat losses very, but usually, values of 50 per cent and 25 per cent, respectively, are assumed correct. (10)

From heat production, heat-loss, and surface-temperature relations it is possible to develop a quantitative relationship between the comfort temperatures of ambient air and the corresponding surface temperature of the surroundings. The effective temperature of all the surrounding walls, taking into account shape factors and temperatures, is termed the mean radiant temperature, mrt, and is the temperature of a uniformly heated room in which the occupant would experience the sane net 
radlant heat loss as in an actual room.

The problem of writing comfort equetion is, therefore, one of relating, for a condition of optimum confort, the air temperature, $t_{1}$, and the mean radient temperature, mrt. The rate of heat loss by evaporation nay be assumed to be constant throughout comfort conditions. The rate of heat loss by raciation $1 \mathrm{~s}$ epproxinately twice that by convaction at $74^{\circ}$. (11) For optinum comfort the rate of heat loss must renain the same for all equilibrium air tenperatures; therefore, when the air terperature is altered, the resulting change in convection heat loss must be exactly offset by radiation heat $108 s$. It follows that.

$$
\Delta t_{1}\left(h_{c}\right)+\Delta \operatorname{mrt}\left(h_{r}\right)=0
$$

where $h_{c}$ and $h_{r}$ are the convection and radiation heat loss coefficients, and $\Delta t_{1}$ and $\Delta$ mrt are corresponding, but opposite changes in $t_{1}$ and art. Since $2\left(h_{0}\right)=h_{r}$, this equation reduces to the following:(12)

$$
\begin{aligned}
& \Delta t_{1} h_{c}+\Delta \operatorname{mat}\left(2 h_{c}\right)=0 \\
& \Delta t_{1}+\Delta \operatorname{mrt}(2)=0 \\
& \frac{\Delta t_{t}}{\Delta \operatorname{mat}}=-2
\end{aligned}
$$

Thls equation indleates that a 1 of increase in sir temperature would be equivalent to a $0.5^{\circ} \mathrm{F}$ decrease in mrt. The above would be true if the body tenperature remained constent. Actually, however, experimental data reported in the literature indloate that body surface temoerature varies as a function of air tenperature. Taking into account this body surface temperature variation, Raber and fatchinson in their book "Panel Heating and Cooling Analysis", show that the retio of equation (13) approeches unity. (13) This indicates that for maintenance of comfort conditions a change in air temperature must be accompanied by an opposite change in mrt 
of Ilke amount.

If a room having a $70^{\circ} \mathrm{F}$ air temperature and a uniform wall surface tempereture of $70^{\circ} \mathrm{F}$ is taken as representative of optimun comfort, then the one-to-one reletionship can be written in the form of a confort equation,

$$
\frac{t_{1}+m r t}{2}=70
$$

giving,

$$
t_{1}+\operatorname{mrt}=140
$$

The term mrt, as ueed by previous investigators, to impraotical for use in calculations where extreme accuracy is not required since it can only be detemined by using accurate shape factors and average teaperetures. For most csses, it cen be shown that by assuming each wall area to have shape factor of unity and by celculating a weightod average, littie error is introduced. (14) The everage surfece temperature, ast, may bo calculated as follows:

$$
\text { ast }=A_{W} t_{W}+A_{D} t_{D}+A_{W} t_{F}=m r t
$$

where $A$ and $t$ are area and tamperature, and the subscripts ${ }^{2}, D$, and $F$ stand for walls, dock, and floor.

The comfort equation, therefore, reduces to

$$
t_{1}+\text { ast }=140
$$

where $t_{1}+$ est is defined as the comfort index. The comfort index in a tent or shelter necessary for comfort conditions will very over wide range, depending unon the activity or type of work being done. When a person performs work, heat is liberated within his body. To remain comfortable, this heat should be lost without increasing body surface temerature. This can only be accomplished by reducing afr or wall temperam 
ture, or both.

The above equation (16) is besed on nomal person, lightly clothed, seated or at rest. However, a lower comfort index would seem reesoneble for troops in army clothing and wh some activity. Estimating thet troops would be confortable when exposed to air and wall temperatures of 60 to $65^{\circ} \mathrm{F}$ a comfort Index of 120 to 23018 obtained.

Over ilmited range of wind velocities a relationship between the confort index, the outside sir, and the type of liner and tent can be developed.

The heat loss from tent has been taken as the product of an overall heat transfer coefflcient, the area of the fabric in the tent, and the temperature difference between inside and outside air.

$$
q=U A\left(t_{1}-t_{a}\right)
$$

This calculation is mede neglecting ground heat Ioss, but nevertheless gives comparative results, since the oversil coefficient, $U$, also is based on the inside area of the tent, thereby negleoting the ground area.

The heat loss from a tent also must equal the heat loss from the contents to the fabric. Tris los can be expressed ss product of an individual heat transfer coefficient, the area of the fabrio in the tent, and the tampersture difference between the air and the febric.

$$
q=h_{18} A\left(t_{1}-t_{8}\right)
$$

Since the temperature of the fabric in a heated tent varies from place to place, the average surfece temperature, ast, is used in place of $t_{s}$, and

$$
q=h_{18} A\left(t_{1}-8 s t\right)
$$

Solving equations (3) and (18) for $t_{1}$ and ast, respectively, gives the 
following:

$$
t_{1}=\frac{q}{U A}+t_{2}
$$

and

$$
\text { ast }=t_{1}-\frac{q}{h_{1 s} A}
$$

Adding and arranging equetions (19) and (20),

$$
t_{1}+\text { ast }=t_{a}+t_{1}+\frac{g}{1}\left(\frac{1}{0}-\frac{1}{h_{1 s}}\right)
$$

Substituting for $t_{1}$ on the right side of equation (21) its equivalent fron equation (19),

$$
t_{1}+a s t=2 t_{a}+\frac{g}{A}\left(\frac{2}{0}-\frac{2}{t_{1 s}}\right)
$$

where the left side of the equation had previously been defined as confort Index. Letting $T=t_{1}+$ ast, and $V=\frac{2}{U}-\frac{1}{h_{1 s}}$. Equation (22) reduces to

$$
T=2 t a+\frac{q w}{x}
$$

Then the comfort Index is evaluated in terms of the outside a1r tempersture, $t_{a}$, the heat input per unit time of the hester, $q$, the tent area, $A$, and the overell and the effective coefficient of heat trensfer for the Ilner, 0 and $b_{1 s}$, respectively. 
SUMAR PHASE CONSTDERATIONS

A fly used wth a tent es in sumer phese temperature control acts as a radiation interceptor. The temperature that this fly attains depends upon its ebsorptivity, enissivity and the rate at which it loses heat by convoction and radiation. once a $2 y$ has been placed between the sun and the tent, the tent receives heat only by radiation from the fly since it is hotter then the ambient eir or Eround. The tent fabric will absorb radiation from the fly and in turn lase it by radiation to the surroundings, convection to the ambient air, and convection to the air with the tent, thereby raising the inside air temperature. The relation can be expressed nathematically by the following equation:

$$
\begin{aligned}
& q=0 A\left(T_{D_{y}}{ }^{4}-T_{D}^{4}\right) F_{A} F_{E}=0 A^{\prime}\left(T_{D}^{4}-T_{B}^{4}\right) F_{A}^{\prime} F_{E^{\prime}}+h_{c} A^{\prime}\left(t_{D}-t_{a}\right) \\
& +h_{c}^{\prime} A^{\prime}\left(t_{D}-t_{1}\right)+0 A^{\prime}\left(T_{D}^{h}-T_{P}^{4}\right) F_{A}^{\prime \prime} F_{E}^{\prime \prime}
\end{aligned}
$$

where,

$$
\begin{aligned}
& -\quad=0.173 \times 10^{-8} \text { Stefan-Boltzmann constant } \\
& A \text { = surface aros of the } \mathrm{fly} \\
& \mathrm{T}_{\mathrm{fl}}=\text { absolute temperature of the } \mathrm{fy} \\
& \mathrm{T}_{\mathrm{D}}=\text { absolute temperature of the deck } \\
& F_{A}=\text { area factor } \\
& F_{\mathrm{E}}=\text { omissivity factor } \\
& A^{\prime}=\text { strfece area of the tant } \\
& \mathrm{T}_{\mathrm{g}}=\text { absolute temperature of the ground or surroundings } \\
& h_{0}^{\prime}=\text { individal coefflcient of heat loss } \\
& t_{a}=\text { temperature of ambient air } \\
& t_{1}=\text { temperature of atr Inside the tent } \\
& \mathrm{T}_{\mathrm{f}}=\text { absolute temperature of the tent floor or ground eloth. }
\end{aligned}
$$


If In order to compare the effectiveness of two flles, two tents of Identical size, shape, and material are used, then, the surface area of the tent, $A^{\prime}$, the area factors for radiation, $F_{A}^{\prime}$ and $F_{A}{ }^{\prime}$, and tho emissivity factors for radiation, $F_{\mathrm{E}}$ and $\mathrm{F}_{\mathrm{E}}$, will be the sene for both tents. If the tent-ny combinations are compared at the same time the outside alr tomperature, $t_{a}$, the wind velocity and hence, the coefficient, $b_{c}$ a function of the wind velocity, w11 be indentical for both combinations. If the two fles are of 1dentical size and shape, then the surface area of the flles, $A$, and the area factor for rediation from the fly to the tent, $F_{A}$ Fil be the seme. Therefore, in compering the effectiveness of two flies of sintlar shepe, the factors related to the confort of the occupents (Inside alr temperature and Inside sirface temperatures) are a function of the temperture of the fly and its enfsgivity factor for ridietion, both of which are related to the enissivity and aboorgtivity of the Iy fabric.

Fron equation (2h) it can also be seen that another effective method of reducing inside air and tent surface temperatures would be to Increase the wind velocity ard thus incresse the coefficient of heat losa from the tent, $h_{c}$. 
EXPERIDENTAL 
PART I TEMPRATURE CONTEOL IN TENTS - WIHTER PHASE

The experimentel work was carried out in a cleared area adjacent to the University of Loulsville Institute of Industrial Research with the terials and equipment listed below.

(1) IIners and Tentage

3 - Large wal1 tents ( 15 by $15 \mathrm{ft}$.

$3-12.29 \mathrm{oz}$. ground cloths (15 by $15 \mathrm{ft.}$ )

1 - $4 \mathrm{oz}$. white cotton liner (large well)

1 - 8 oz. 0.D. 7 cotton IIner (1arge wall)

$1-1 / 2$ inch thick fiberglas liner (large wall)

1 - Squad tent, $x-1945$

1-12.29 oz. Eround cloth (squad tent)

1 - 4 oz. White cotton Iiner (squad tent)

1 - 4 oz. whtte cotton Liner, low profile (squad tent)

$1-1 / 2$ Inch thick fiberglas liner, low proflle (squad tent).

The regular iners in these tents were suspended so that an air space of approximately 6 lnches was formed between the liner and tent. The Low profile Iiners were made wh a maximun head helght of 7 feet, forming when Installed large dead air space in the peak and a-inch space between the Iner and the tent on the sides and deok up to 7 feet. Both types of Inners were fastened to the rldge pole by tapes passing between the ridge pole and the deck fabrics. Both types also were secured at the eaves by tapes through netal rings sewed to the fabric. The Iiners in the large wall tents were completely inslde the supporting poles, whereas the supporting poles passed through an 8-inch opening in the peak of the squad tent Iner. 
The fiberglas liner was made of an $1 / 2$ inch thick ftberglas pad quilted between two layere of 4.0 or. white cotton sheeting.

(2) Heating Units

The heating units consisted of six 550-watt cone hesters in sockets nounted on a transite base and shielded with galvanized iron to prevent direct radiation to the fabric. Bach tent was equipped with a 110-rolt switch box and connection to the heaters.

\section{(3) Instruments}

The heet supplied to each tent was detemined by calculations from a measure of the electrical power consumption.

Atr teaperatures were messured with mercury in glass thernometers. Fabric, and ground temperetures were mesured with 30 gauge copper-constantan thermocouples through a selector switch to a direct, rading potentiometer.

Humiditles were obtained with sling psychrometer and outside wind velocities with a 3 oup anenoneter 7 feet above ground level. The tents, with ridge poles North-South, were equipped with ground cloth, heaters, selector switches and liners. Thernoneters and thernocoxples were placed as shom in $\mathrm{Flgure} 1$.

At the beginning of a run, air, tent fabric, liner fabrle, gro and temperatures, and the relative humidity were measured, the heaters turned on, and these data recorded on previously prepared data sheets (see Figure 22) every 15 minutes until equilibrlum was obteined. Funs lested for two or more hours and several readings were made after equilibrium to obteln accurate sverege temperatures. Blectricel power to the heaters, outside weather conditions, such as wind velocity, wet bulb temperature, dry bulb temperature, ground temereture, etc, wera recorded during esch 


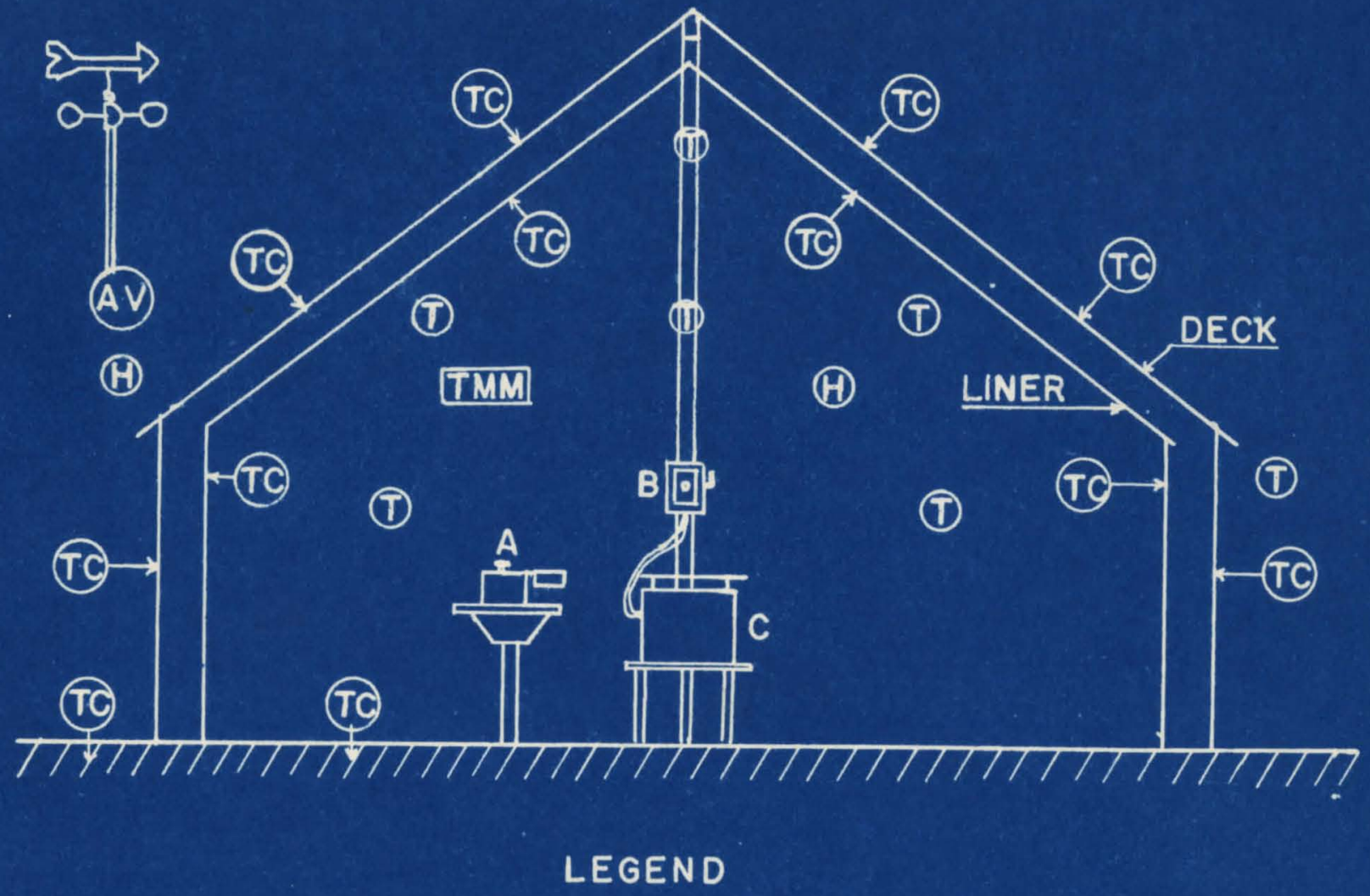

A POTENTIOMETER AND TEN POINT SELECTOR SWITCH

B SWITCH BOX FOR HEATER

C ELECTRIC HEATER

(T) THERMOMETERS $10-220^{\circ} \mathrm{F}$

(TC) THERMOCOUPLE CU-CONSTANTAN

TTMM MAX-MIN THERMOMETER

(H) RELATIVE HUMIDITY

(AV) AIR VELOCITY

LOCATION OF MEASURMENTS IN TEMPERATURE CONTROL TENT 
mun. On muns lasting longer than two hours, half hour or hourly readings were taken after equilibrium was reached.

The tents ware laced at all times during the runs except for the perfodic recording of readings.

A total of 30 runs were made in which data were taken either on three large wall tents or one large wall tent and one scuad tent. Of these, 2 were of 24 hours duration, 8 were at night, and 20 were dey rins. of the day runs, 6 were with a heavily overcast sky and the reneinder on days when the sun was shining 30 to 100 per cent of the time. Each tent in each run was assigned test number. Then all tests were catalogued aecording to tent assembly, hest input,

In the various mus, air temperstures inside the tent were recorded at levels 3 feet, 5 feet, and 8 feet above the floor. Feadings were taken in the four corners (three feet Prom each well) and in the center of the tent, as shom on the sample date sleet. These values were used to obtain the everge air temperature at exch helght.

During a run these temperatures varted as the outside air termperature solar radiation varied. A plot of the temoeratures at the various levels against the time of day is shown in Flgure 2. It is observed that the inside tempertures followed closely the slope of the outside eir temperature cirve at a given hest input. The reletively high temperatures at 11:00 A.M. and 3:30 P. we were due to decrease in heat loss from the tent surface because of the more direct radiation of the sun on the tent deck.

For purposes of calculation it is desirable to obtaln a bulk or average inside air tenperature. If the air temperature (ordinate) is plotted as a function of some independent variable $(x)$ such as volume 


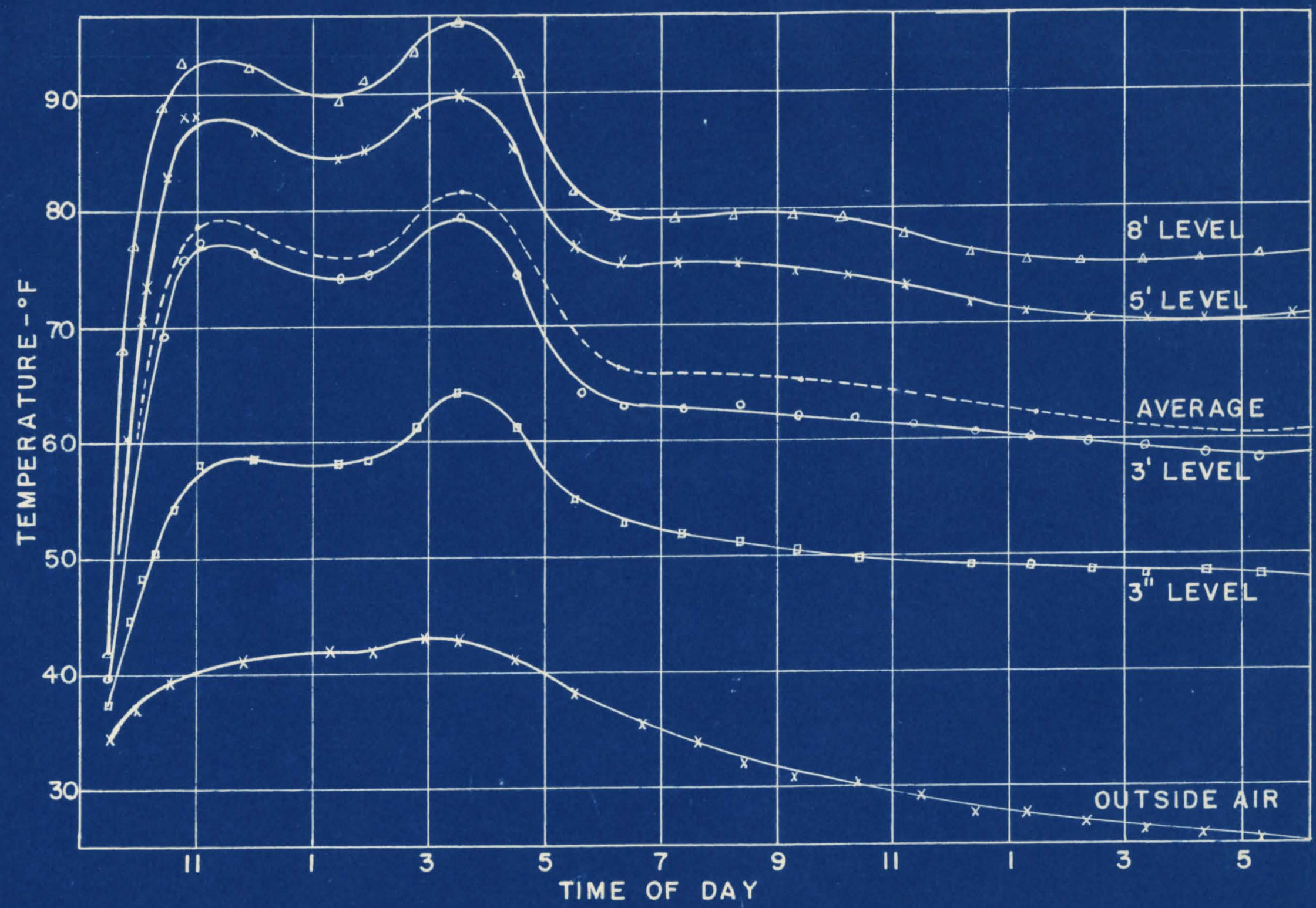

INSIDE AIR TEMPERATURE VERSUS TIME OF DAY

FIGURE 2 
(abscissa), its average value can be found by dividing the area under the curve by the abscissa range where the area under the curve is given by

$$
\int_{x_{1}}^{x_{2}} f(x) d x
$$

and

$$
t_{\mathrm{ave}}=\frac{\int_{x_{1}}^{x_{2}} f(x) \mathrm{d} x}{x_{2}-x_{1}}
$$

A plot of temperature versus cumulative volume produces approxdmately a straight line, whereas plot against height geve a curved line. If the straight Iine relationship is used, equation (25) cen be simplified as follows:

$$
f(x)=t=a+b V
$$

where 'a' represents the intercept of the line with the ordinate, and $b$ ' the slope of the stralght line. Substitution of this function in equation (26) ylelds,

$$
t_{\text {ave }}=\frac{\int_{0}^{\nabla}(a+b V) d V}{V}=\frac{a v+\frac{b v^{2}}{2}}{V}=a+\frac{b V}{2}
$$

However, $a=t_{1}$ and $b=\frac{t_{2}-t_{1}}{\nabla}$,

where,

$$
\begin{aligned}
& t_{1}=\text { air temperature on the floor } \\
& t_{2}=\text { air temperature at the roof. }
\end{aligned}
$$

Therefore,

$$
t_{\text {ave }}=t_{1}+\frac{t_{2}-t_{1}}{v} \times \frac{v}{2}=\frac{t_{1}+t_{2}}{2}
$$


This celculation of $t_{\text {ave }}$ is equivalent to salecting the tengerature at midvolume and is the method used in obtaining the valuas for average inside afr temperature used in this work. A typleal plot of the temperature versus cumulative volume is shom in Pigure 3 for the various tent-1iner combinations. In all ceses, the best stralght line wes drawn through the given points. It is noticed that the average temperature did not occur at mid-height but more nearly $1 / 3$ of the height. A plot of this average inslde eir temperature versus time of day is shown on Figure 2. It wa found to follow tre contour of the three-foot level, and was the temperature at about $31 / 4$ feet above the floor for the 4 oz. 1iner. In all future discussion, this average inside air temperature $\left(t_{1}\right)$ will be used. Fgures 4 and 5 show typleal plot of temperature versus time of day for the liner and tent fabric. Since $12.29 \mathrm{oz}$. duck, 0.1. 7, hes such a high absorbtivity, it is preatly affected by sun radiation. During the collection of these particular data the sky was overcast except for a short time in both the morming and afternoon, when the east and west decks, respectively, showed marked increases in temperature. It wes also observed that even when the sky was heevily overcest, as at $1: 30$ P.M., the tent was receiving raciation from the sky, indicated by the higher fabric temperatures before sun-dow.

An examination of the data as outlined above indicated a mintmum of sky radiation to the tents between nidnight and 2:00 A.M. Hence, deta from this period were employed in the calculation of heet loss coefflcients.

The per cent sun recorded on the data sheets was obtained from the weather bureau station and gives the percentage of the time during the dey that the sun's radiation was above a certain minimum intensity, which 


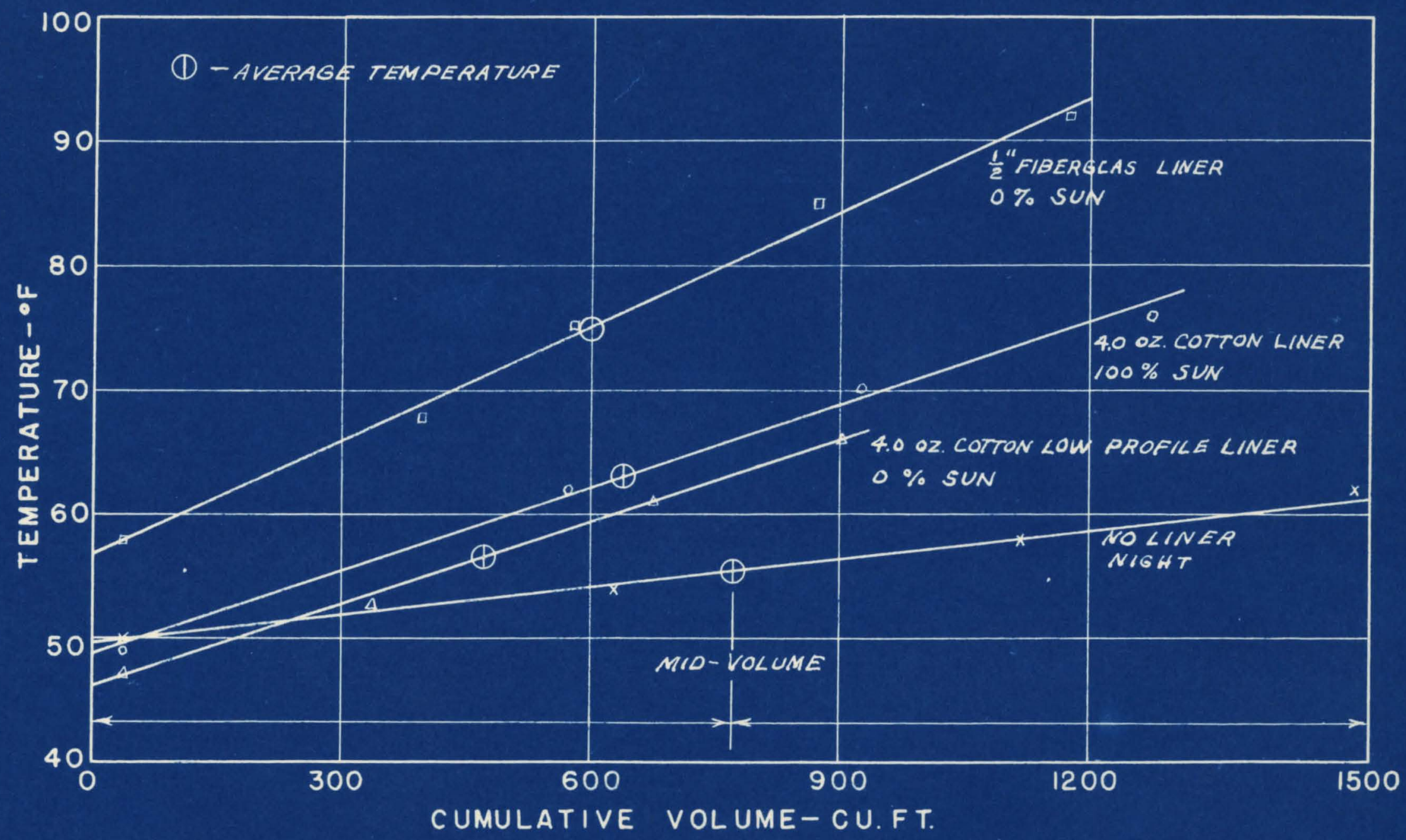

INSIDE AIR TEMPERATURE VERSUS CUMULATIVE VOLUME FIGURE 3 


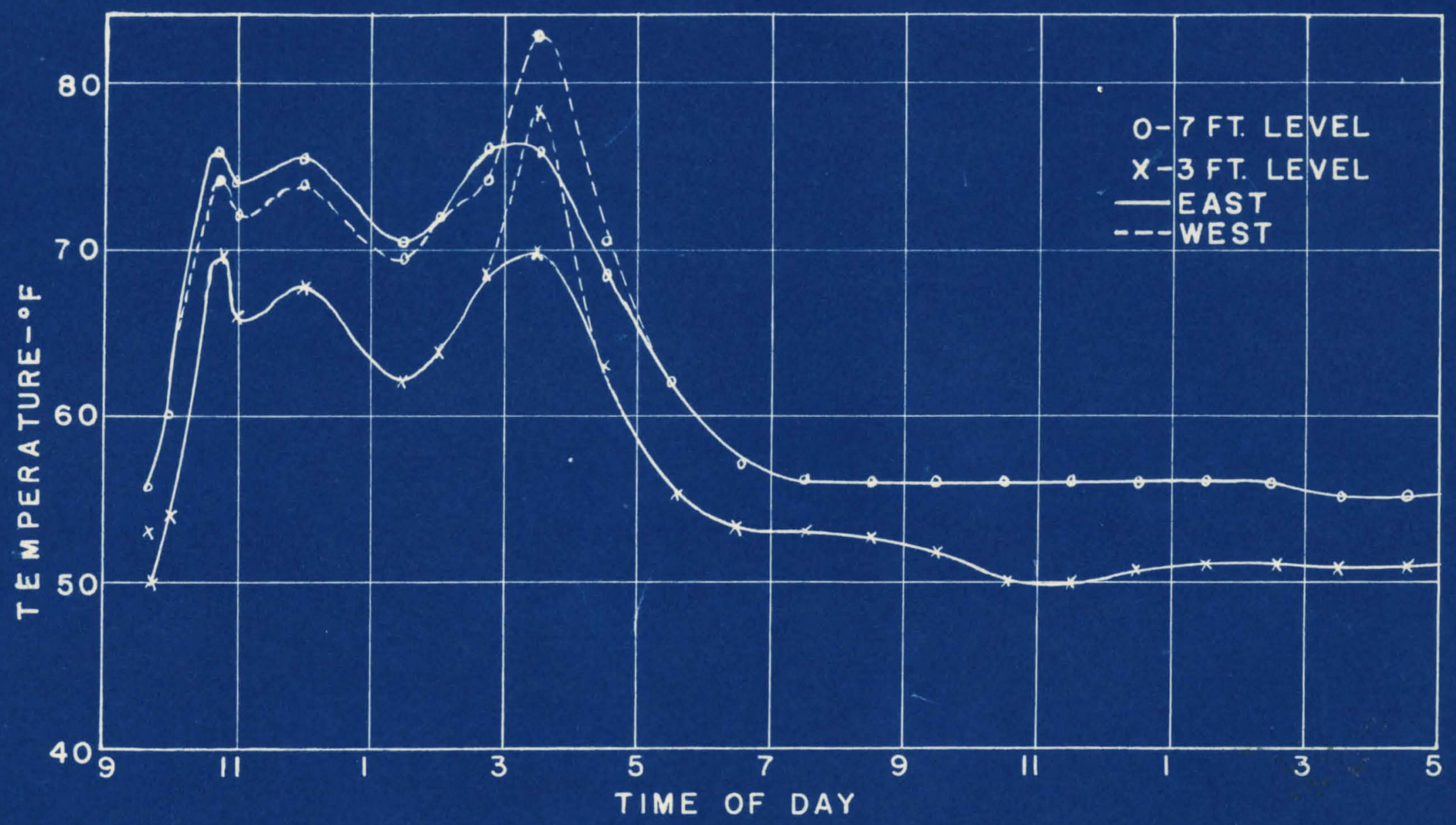

LINER TEMPERATURE VERSUS TIME OF DAY LARGE WALL TENT 4.0 OZ. WHITE COTTON LINER

FIGURE 4 


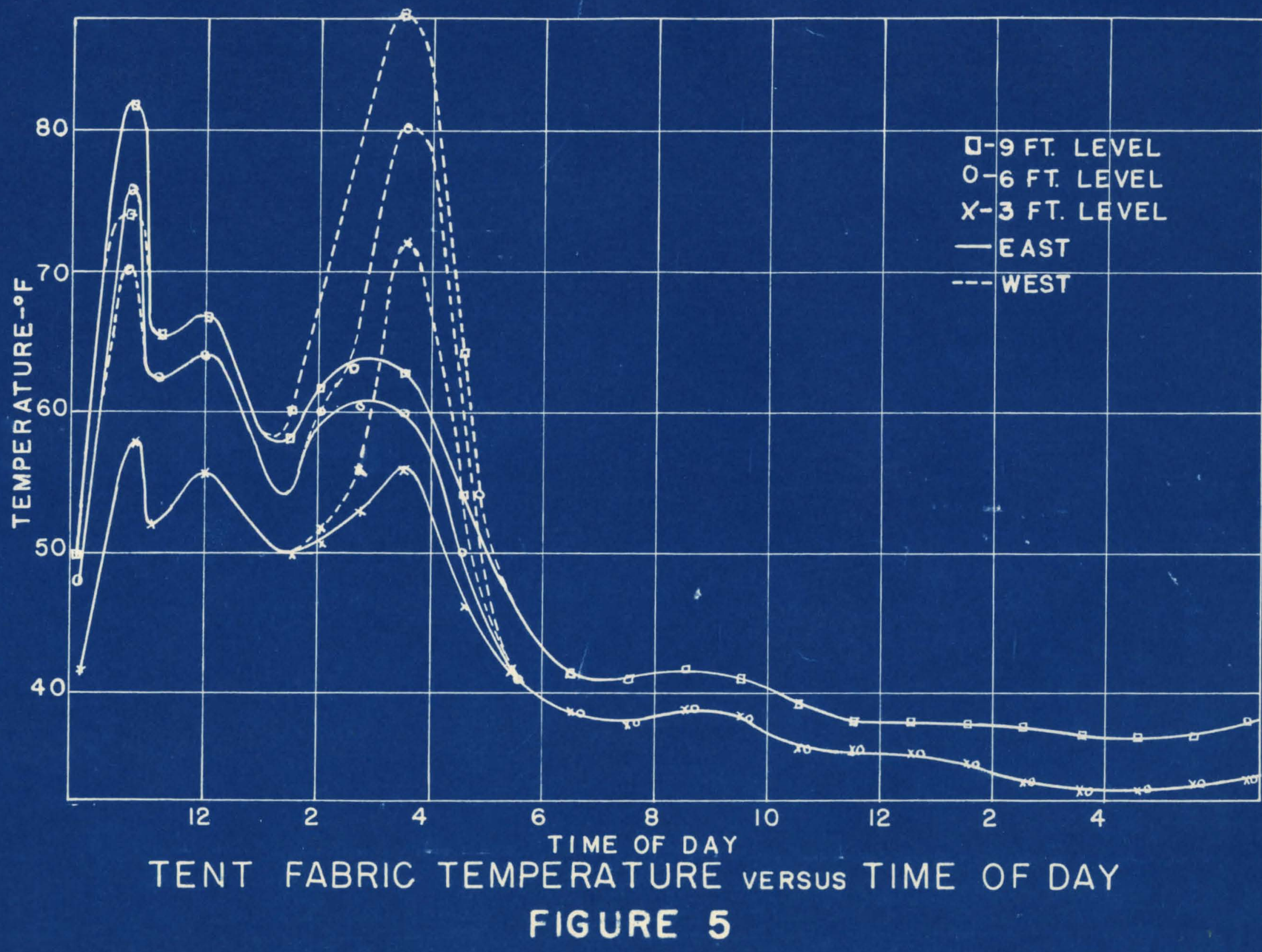


is the average value recorded on clear or slightly cloudy days. Both the morning and afternoon peaks, on F1gure 5, were recorded as 100 per cent sun, though the average for the day was only 24 per cent sun.

For both the tent fobric and the liner, an average temperature was calculated by weighting the temperature of the varfous tent or liner sections, such as sides, decks, and ends, according to surface area assuring a shape factor of 1 . Oniy these average values were used for calculations.

The bourly readings that showed the nost constant condition of equilibrium were chosen for each test and these data used for the calculations. Average vilues of air, tent fabric, liner, ground, and floor temperatures for these equilibriuxa periods during ell runs are shown in Table 4 in the Appendix.

Figure 6 is a plot of temperature versia time of day for the average air snd surface temperstures over a 24 -hour period for a large wall tent with $4 \mathrm{oz}$. cotton liner and, it is observed thet the air and fabric temperatures rapidly fall at sundown and remain relatively constent, decreasing slightly until sunrise. This same general trend was found in all tents with the greatest variations in a tent without liner, and the least when the fiberglas liner was used.

Since a person does not necessarily occupy only that part of the tent shoming the average temerature, Figure 7 was made to show the tempereture distribition in the various tents and liners. In each case, the everage inside air teraperature was $62^{\circ} \mathrm{p}$, but the hoight in the tent at which this exact tempereture was found varied from 3 feet for the low prorile $4 \mathrm{oz}$. Inner in the large wall tent to $41 / 2$ foet for the squad tent with no liner. Again, a man stending in a squad tent with no liner 


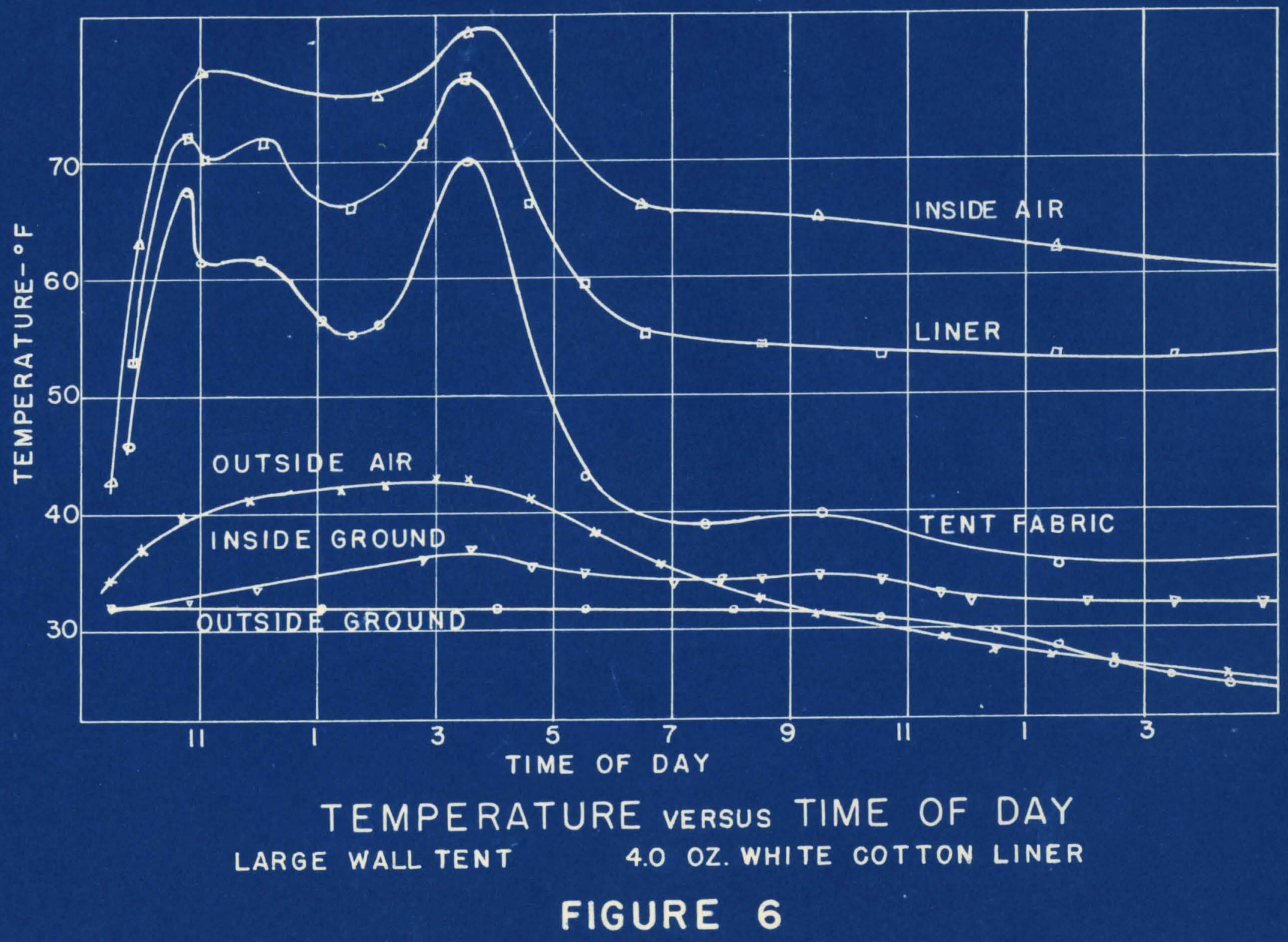




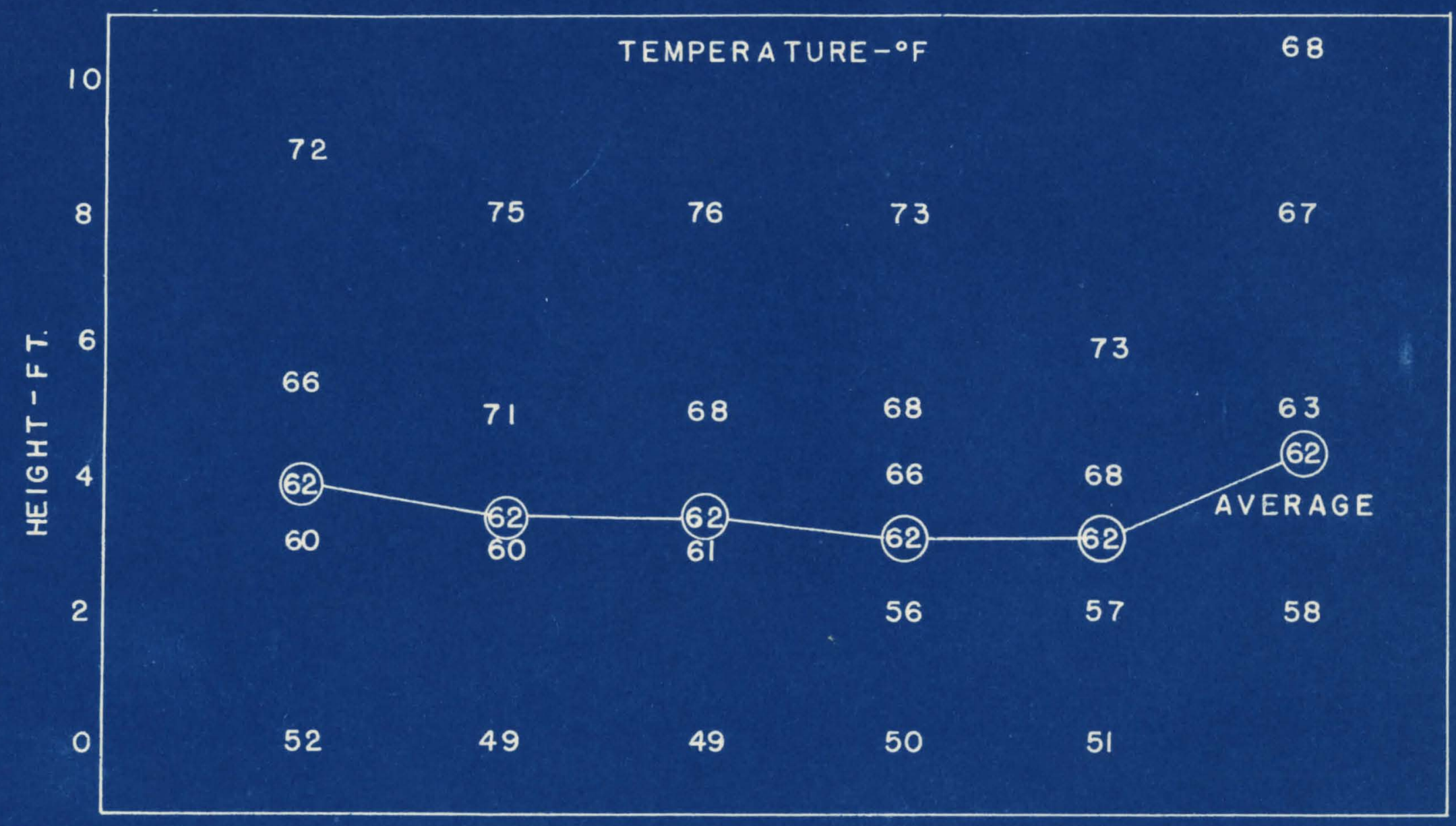

TENT LARGE WALL LARGE WALL LARGE WALL LARGE WALL LARGE WALL SQUAD LINER NONE 4 OZ. COTTON 8 OZ. I/2" 4 OZ. COTTON NONE AIR TEMPERATURE DISTRIBUTION INSIDE TENTS FIGURE 7 
would be exposed to a temperature of $64^{\circ} \mathrm{T}$ at head level, whereas, if he were in a large wall tent with a low profile $4 \mathrm{oz}$. cotton 1 iner, the tempereture at head height would be $72{ }^{\circ} \mathrm{F}$. The temperatures below the 5 foot level, however, do not vary appreciably for the same type of tent, regardless of the type of liner. The low profile liner did give I to 3 degrees higher temperatures at any given level than the sane liner in the more conventional position of 6 inches from the tent febric.

Vartous surface and overall temporature differences for all the runs are show in Table 5 in the Appendix. In this table, wide veriations in the taperature differences are observed for the same heat input. These differences resulted from the presence or absence of solar or sky radiation. Since no measure of the sun's intensity was mede, calculations could be based only on the known heat input of the heaters, and no dirset comparison could be made between dey-runs and night-runs except in those cases of heavy overcest during the day. For instance, a $\Delta t_{\text {fa }}$ (inside air minus outside air) of $16.5^{\circ} \mathrm{F}$ wos obtalned at night with a heat input of 12,550 BTU/Hr., whereas a $\Delta t_{12}$ of $35.8^{\circ} \mathrm{F}$ was abtained during morning mun whth only 11,750 BTU/Hr, heat input from the electric heaters with other conditions the same.

To conpare tre insuleting velue of the several liner-tent combinatlons, use was made of the overall coefficient of heat transfer, 0 , expressed in BTU/(fr.)(sq. ft.) $\left({ }^{\circ} \mathrm{F}\right)$ as calculeted from the equation

$$
q=U A \Delta t
$$

In order to learn more of the nature of the heat transfer, the Individual coefficients of heat loss, $\mathrm{h}$, were calculated according to the equation

$$
q=h^{\prime} \Delta t^{\prime}
$$

where $h$ ' is expressed in the same units as $U$. 
Values of the overall and Individual coefficients are shom in Table 6 in the appendix.

In the derivation of the above equations, it was assumed that the heat loss to the ground was negligible. Although undoubtedly the heat lost to the ground from the tent is appresiable, the calculated coeff1cients are usable for comparisons. Two tents with the sane inside air temperatnre mould have the sime heat loss to the ground regerdless of the type of IIner, though not necessarily the same percentage of heat loss to the eround. Furthermore, the value of a employed in the calculations wes the total heat loss, whether tine loss was through the tent fabric or floor. Therefore, use of coefflcients calculated in this manner gave correct heat requirement quentitios as long as the ontside air and temperature of surroundings were approxinately equal. These ideas were subatantiated when the use of one-inch thickness of Piberglas on the floor gave the seme overall coefficient of heat loss as was obtained with a regulas 12.29 oz. ground cloth and a tent with no ground cloth.

If the temperatare of the surroundings is assuned to be the tempereture of the ground surfece outside the tent, values of equivalent air tempartures cen be calculated ecordint to eqration (10) which becomes,

$$
t_{\mathrm{ag}}=2 t_{\mathrm{a}} / 3+t_{\mathrm{b}} / 3
$$

where $t_{\text {ag }}$ represents the equivalent alr temperature. overall and individual coefficients of heat loss were celcuated, using this equivelent air tempereture, for all overcest and night runs where the temperature of the surroundings differed appreciably from the outside air temperature. These values are show in Table 6 in the Appendix. 
The table belor shows the finel averages for the varlo:s Iinertent combinations for night and overcast day runs (zero per cent sun).

TABLE 1

AVERAGE HEAT LOSS COEFFIC TENTS

Type Itiner

Overall Coeffleients of Heat Loss

$\left(\mathrm{U}_{\mathrm{lag}}\right) \mathrm{BTU} /(\mathrm{Hr}).\left(\mathrm{sq} . \mathrm{ft}_{*}\right)\left(\mathrm{O}_{\mathrm{F}}\right)$

Nio Iner

1.26

4 oz. White Cotton isner

0.58

8. 0.0. 7 Cotton Liner

0.58

$1 / 2$ inch Mberglas liner

0.39

The maximum deviation of the overall coefficient from the average value is 10 per cent for the tent with no liner, 4 oz. 1iner; and $8 \mathrm{oz}$. Iiner; but 30 per cent for the $1 / 2$ inch thlok flbarglas 1 iner.

Wille the overall coefficients give a good compaxison of the relative insulating vilues of the various 1iners, they consider only the average inside air temperature to which a tent occupant is exposed. A more useful comparison is besed on the confort index concept as shown by equation (16)

$$
\text { Confort Index }=t_{1}+\text { ast . }
$$

To obtain the comfort index the average surface temperature was calculated by takdng weighted average of the Inside surface temperatures of the decks, ends, side wells, and floors and this value added to the average inside air temperature. Comfort Index velues are show in Appendix Table 7 .

If It is assumed thet the overall coeffictent is constant for outside air temperatures between 20 and $40{ }^{\circ} \mathrm{F}$, the comfort index for aight and overoast day mus can be recalculated for an outside temperature of $32^{\circ} \mathrm{F}$. 
Figure 8 shows a plot of heat input versus confort index for an outside temperature of 32 of. Three groupings of the data were found through which straight lines could be drow, viz., the deta for the $1 / 2$ inch thick fibarglas liner, the 4 and $80 \%$. cotton liners, and the tent with no 1 iner. For a comfort index of 120 the relative mounts of heat necessary in large wall tents equipped with these Iiners nay be detemined from Flgure 8. To maintain this comfort index of 120 with outside air at $32{ }^{\circ}$, hest Inputs of $7,000,11,900$ and $27,500 \mathrm{BTw} / \mathrm{Fr}$. would be required for lerge well tents equipped with $1 / 2$ inch thick flberglas liner, 4 or 8 oz. cotton liner, and no liner, respectively.

The left hand termint of the confort index lines of Flgure 8 were dram through a confort index value of 6h, Instead of the actual data, as this value is theoretically correct for an air temperature of $32{ }^{\circ} \mathrm{F}$ with no heat input. The ectual data fell below this value because of the subcooling of the deck at night relative to the ambient air temperature. During the early night hours the anbient eir temperature decreases slowly because of the high heat eapacity of the oarth, whereas the deok fabric of low heat capacity readily lost heat by radiation and cooled the air in the tert. As the night progressed the earth cooled, this subcooling of the tent air dininished and the comfort index approached the theoretical value.

In order to relate 11 the variables coverad with the winter phase consideretions of tents, the nonogram of Flgure 9 was constructed using equation (23). The nomogram actually was combination of three nomograms and related the variables, confort index, ambient air temperatare, overall heat transfer coefflcient, tent fabric area, and heat requirements. This chart was besed on theoretically oorrect equations 


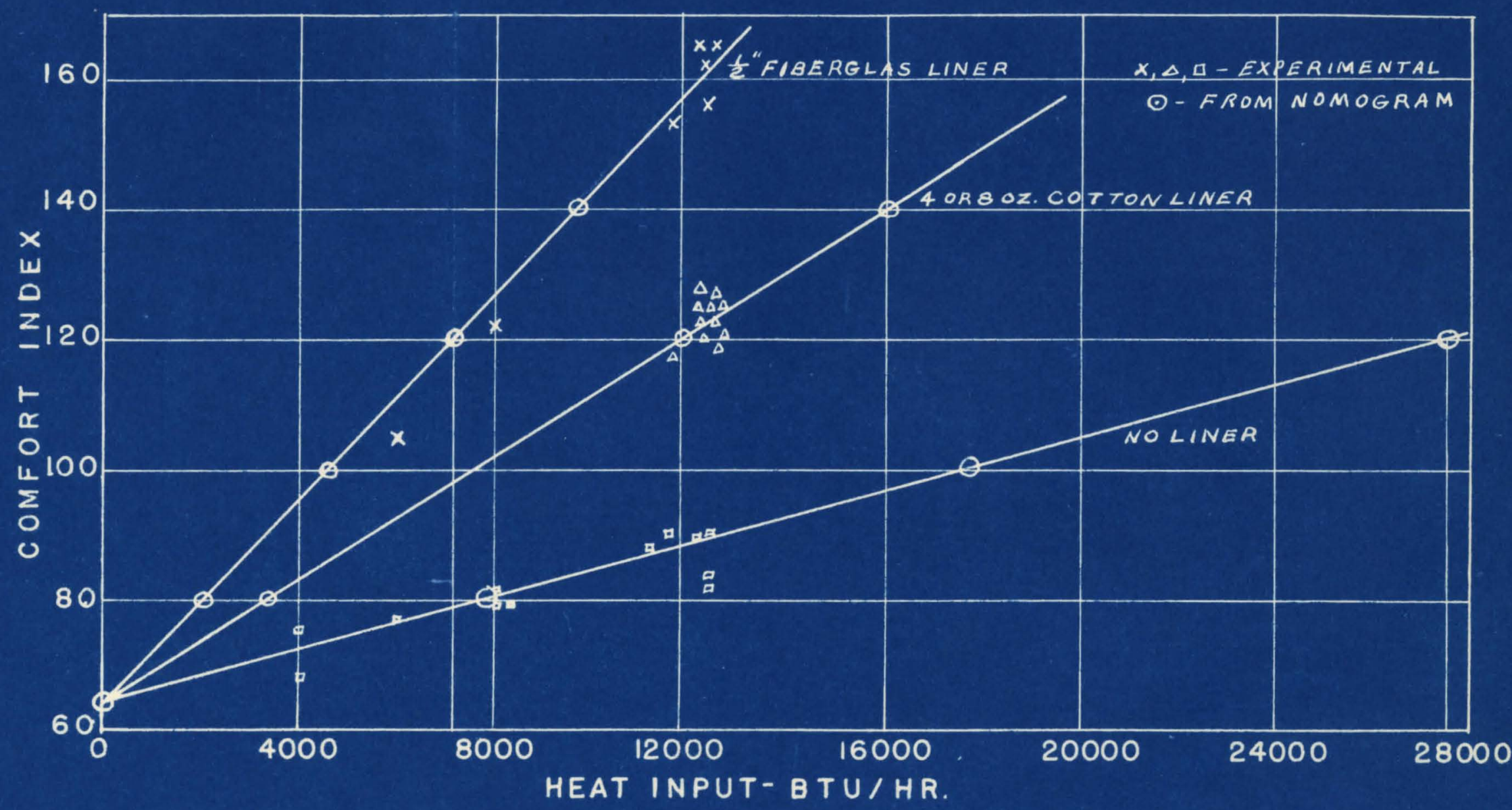

TENT COMFORT INDEX VERSUS HEAT INPUT LARGE WALL TENT OUTSIDE AIR $32^{\circ} \mathrm{F}$ FIGURE 8 


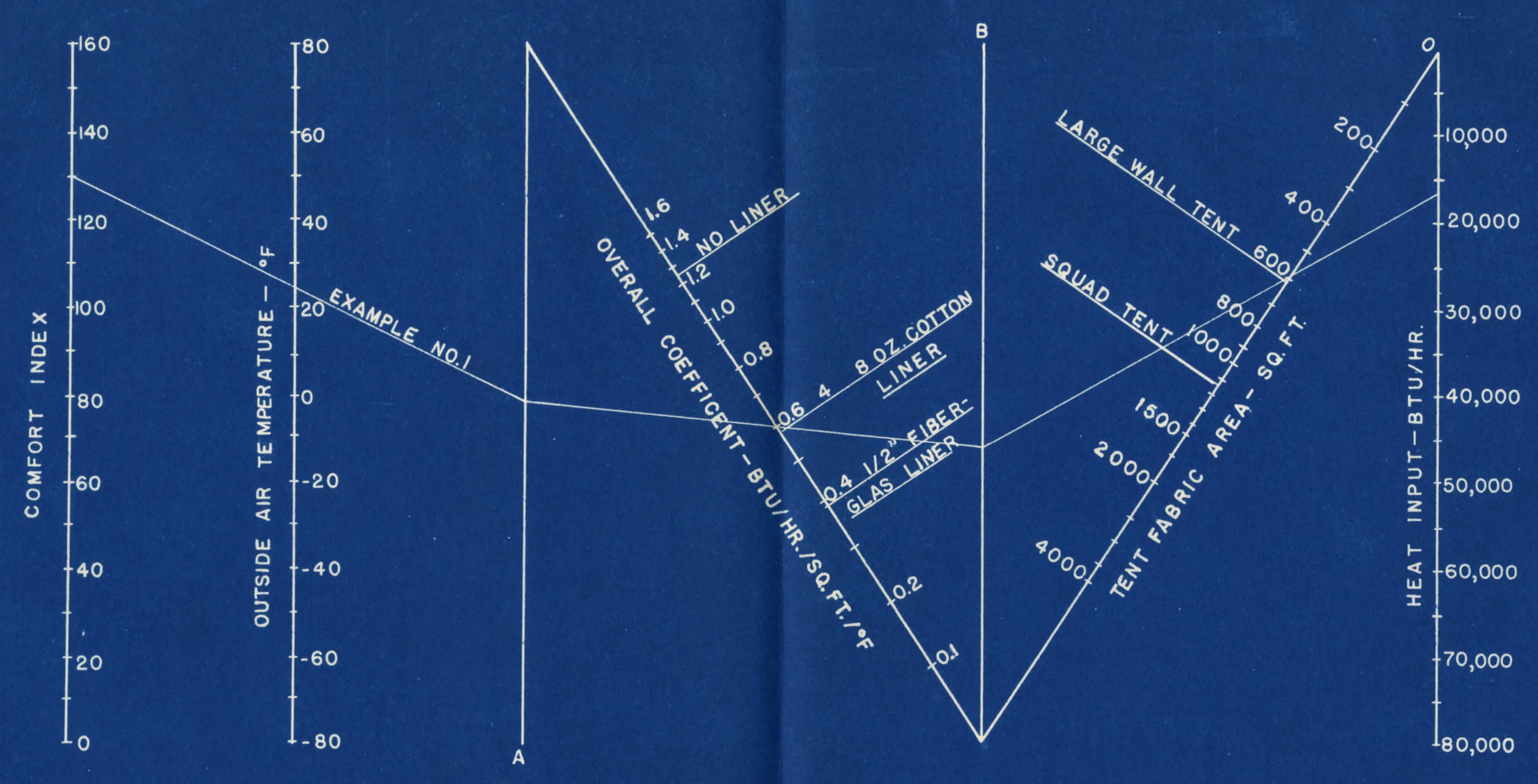

NOMOGRAM FOR THE DETERMINATION OF COMFORT HEATING CONDITIONS 
applying in all cases. The accuracy of the results from this nomograph, however, depended uon the eccuracy of the coefficient, 1 . Since the coefficients calculated for the individual runs included such a variety of uncontrollable factors related to the weather, the u-values used on this chart were calculated from the more consistent overcest day and night runs and the tent fabric area neglecting ground loss.

\section{Example No. 1}

It is desirod to know the heat requirenents of a large wall tent equipped with 4.0 oz. Iiner to maintain a confort index of 130 , if the outside air temperature is $25^{\circ} \mathrm{F}$ and the sky is overcast and wind velocity is less than $10 \mathrm{mph}$.

\section{Solution}

Connect 130 on the comfort index line with $25^{\circ}$ on the outside air temperature IIne and extend to Iine A. From the intersection on line A, draw a line through the overall coefficient value corresponding to the 4.0 oz. I1ner $(.60)$ and extend to line B. From the intersection on line B connect a line with 600 , the area of the large wall tent and read the heet requirements off the last Iine $-17,000 \mathrm{BTU} / \mathrm{Hr}$.

Example No. 2

Find the heat requirement for a squad tent equipped with a 1/2 Inch thick fiberglas low profile liner with an outside air tempereture of $10^{\circ} \mathrm{F}$ if it is desired to maintain a confort index of 120. Assume wind velocity of 6 mph and night operation.

\section{Solution}

Conneat 120 on the comfort index line ith $10^{\circ} \mathrm{F}$ on the outside air tampersture line and extend to line A. Fron the intersection on Ine A drew a line through the overall coefficient value corresponding to the 
1/2 Inch thick fiberglas liner $(0.39)$ and extend to line B. From the intersection on line B conrect a line with 1,150 , the area of the squad tent, and read the heat requirements off the last 11 ne $-25,00 \mathrm{BTO} / \mathrm{Hr}$.

\section{Example Mo. 3}

Using a large wall tent and a 1/2 inch thick fiberglas liner and a stove with a heat output of $20,000 \mathrm{BTU} / \mathrm{lr}$., find the lowest ontside air temperature chung wet and overcast conditions in which a comfort index of 130 may be maintained.

\section{Solution}

Connect 20,000 on the heat input line with 600 on the tent area Iine and extend to Iine $B$, From the intersection on line $B$ draw $a$ Ine through the coefficient of the fiberglas liner $(0.39)$ and extend to line A. From the Intersection on 1 ine A connect a line with 130 on the confort index Iine and read the intersection with the outside atr temperature Iine $\left(-12^{\circ} \mathrm{F}\right)$.

In the above examples the hest requirenents were based on $v$ values celculated for night and overcast deys. If the same conditions had been desired during a sunny doy, 1 ess heat in ut would have been necessary, since the tent would have received certain anount of heat from the sun.

If the wind velocities in the above exmmles vere sufficiently higher than the range in the experiments, an additional quantity of heat would have been required due to allght increase in heat loss through the febric and a much larger heat loss due to eir leakage.

The overell coeficient may be considered function of the type of 1iner, regardless of the type of tent being used since the heat transfer characteristios of single fabric tents are very sinilar. For 
esse In using the nomograph, various types of liners may be marked on the coefflcient line, and no regard need be given the actual value of the coefflclent. Likentse, tent types may be narked opposite their appropriate areas for ease in use. These adittions have been made to the nonogram in Finure 9.

As a check on the velidity of the results which may be obtained from the nonogrem, heat requirements for various confort indexes were determined at $32^{\circ} \mathrm{F}$. These values were then plotted in Flgure 8 . The theoretical data nay be seon to flt very well the notual experimental dete as shown in Figure 8. This comparison gives a measure of the accuracy of the results which may be obtained from the nomogram.

It is possible, therefore, to deternine heat requirements for any tent-liner arrangement under any temperature condition, so long as the overall coefflciant, U, is knom. It is balleved thet the nomogram is accurate down to $O^{\circ} \mathrm{F}$ and that reasonably accurete values may be obtained below thet termperature.

For the calculated values of $U$ shown in Table 6 , the flberglas Liner is three times as effective an insulator as no liner, whereas the 4 and $80 \%$. cotton liners are twice as effective. That is, for a given outside air temeratire end nomel wind velocities encountered in these rins, it would require three times as moh heat to maintain a tent with no liner at a given inside air temperature as for tent with $1 / 2$ inch thick fiberglas liner. It would raguire twice as much heat to maintein the no Iiner tent at the sane tempereture as the 4 or 8 oz. Iiner tent. Finelly, the $1 / 2$ Inch thick fibergles reprasents a heat saving of two-thirds over the 4 and 8 oz. Ilner tent. Althoigh no night runs were made with the low proflle liner in 
the large wall tent, 1 ts effectiveness can be estinated by comparing the coeffictents for the day runs with those for the conventionsl Iiner on similar day runs. This comparison shows thet the 4 oz. white cotton low profile liner has the sane overall coefficient of heat loss as the conventional $4 \mathrm{oz}$. white cotton 11ner.

Funs 70 through 76 were mede in the squad tent $(1-1945)$. A11 of these runs were made at night, and the coefflelents should be aporoximately the same as the average values obtained for the large well tent with the same liner. An overall coefficient of 1.23 for a squad tent with no liner compares well with the average value of 1.26 for the large waIl tent. However, the next four runs, 72 to 75 , gave $U$ values much higher than were expected from the results of the large well tent. An examination of these date showed that these high results were possibly the result of leakage through the hole in the liner fhere the vertical supporting tent poles passed. Another sun was made with the $4 \mathrm{oz}$. white cotton liner in which the opening around the vertical nole wes elosed with 4 oz. cotton cloth. In this run a coefficient of 0.62 wes obtained which compred favorebly ith the average value of 0.58 for the large wall tant th 4 oz. cotton liner. Slullarly, the other liners in the squad tent could be equipped with "turtle-neck" cloth to close the opening around the vertical pole, and reduce the coefficient to a value comparable to the large wall tent for the same liner.

From Table 6 the average values of the equivalent coefficients $h$ Dag* $h_{18}$ and $h_{L D}$ (both $4.0 \mathrm{oz}$, and $8.0 \mathrm{oz}$. Liners) are 2.5, 2.5, and 1.3, Fsapectively. The coefflcient, hag, represents the equivalent alr Plim from the deck to the outside air, $h_{1 s}$, the air film from the inside air to the Iiner, and, $h_{L D}$, the two equivalent ir films between the Iiner 
and the deck. On the besis of tre two atr films, the average value of a single air filn coefflelent between the liner and deck is 2.6 .

During these investigations, the wind velocity was relatively low, varylng from 0 to 7 miles per hour. At higher wind velocities the outside air film coeficient becones greeter end less resistance is offered to the heat loss, 1.e., the resistence of a film 1 s the rectprocal of the coefflcient, $R=\frac{1}{h}$. From this at nd point, the inside temperstures of the tents without liners are influenced more by winds since the outside film represents approxinately one-half of its total resist-nce to heat flow. On the other hand, the outside film is only one-sixth of the total resistence for the tent with fiberglas liner and wind velocity variations do not influence the inside tent temperfure in this case as much as in the case of the tent with no liner.

Gromet holes, door openings, etc., allow a large number of air leaks in a tent, no mattar how carefully it is pitched. This source of hest loss increases considerably at high wind velocities, but again, the heavier the liner the lower is the loss from winds at opentrigs. For velocities below 10 miles per hour, as experienced in these tests, the increasing heat loss with increasing wind velocity is smell, especially for the fiberglas liner. However, quantitative evaluation of the effect of the wind was obtalned over this range.

The influence of humidity showed no consistent trend, other variables influencing the velue of $U$ to such an extent that any humidity effects were obscured For the nost part. Fun 12, made during a light rain, gave e coeffictent of 1.07 , compared to the average value of 1.26 for the large wall tent with no liner. Run 61 gave $U$ of 0.41 for the $1 / 2$ inch thtck fibergles liner during the rain, whereas the average value 
was 0.39 . The presence of water on the tent deck should decrease the fllm resistance and increase the heat 10ss. However, this effect was not observed during those particular runs in which it rained.

Felative muldity inside the tent varied with the outside hutdIty and decreased as the origlnal volume of air and watar were heated, attaining fatrly constant value after the first hour of heating, and verylng only slightly thereafter with the outside hunidity. The relative honidity in the large wall tent with no liner ren consistently higher than in the tents with Iners.

The values in Teble 6 show that the coefficient for day runs when the per cent of sun was greater then zero were much lower than the averge values calculated for night and overcast runs. As explained previously, this veriation was due to the additional heat given to the tent by the fabric absorbing the sun's radietion and transferring it to the Insice eir.

When equation (3) $q=U A \Delta t$ is plotted, using $A \Delta t_{1 a}$ versus $q$. the heat input from the heaters, the slope of the line is the coefficlent U. Then on deys with significent solar rodiation, $\Delta t_{1 a}$ becomes greater and the slope of the Iine or $U$ becomes less. For the night runs a U-value of 1.26 is calculated from the slope, whereas the line epproximeting 100 per cent sun ives a value of 0.51 . It 4 s observed in Table 6 that the values of overall coeflicients for overcast deys appronch those for night runs. This flgure also shows that for temperature difference between inside and outside eir of $15^{\circ} \mathrm{F}, 11,200 \mathrm{BTU} / \mathrm{Hr}$. Is necessary at night in a large wall tent wh no liner, whereas, only $3,700 \mathrm{BTU} / \mathrm{Hr}$. Is necessary during the day fith 100 per cent sun. Figure 10 is a plot of the effective heat input from the sun 


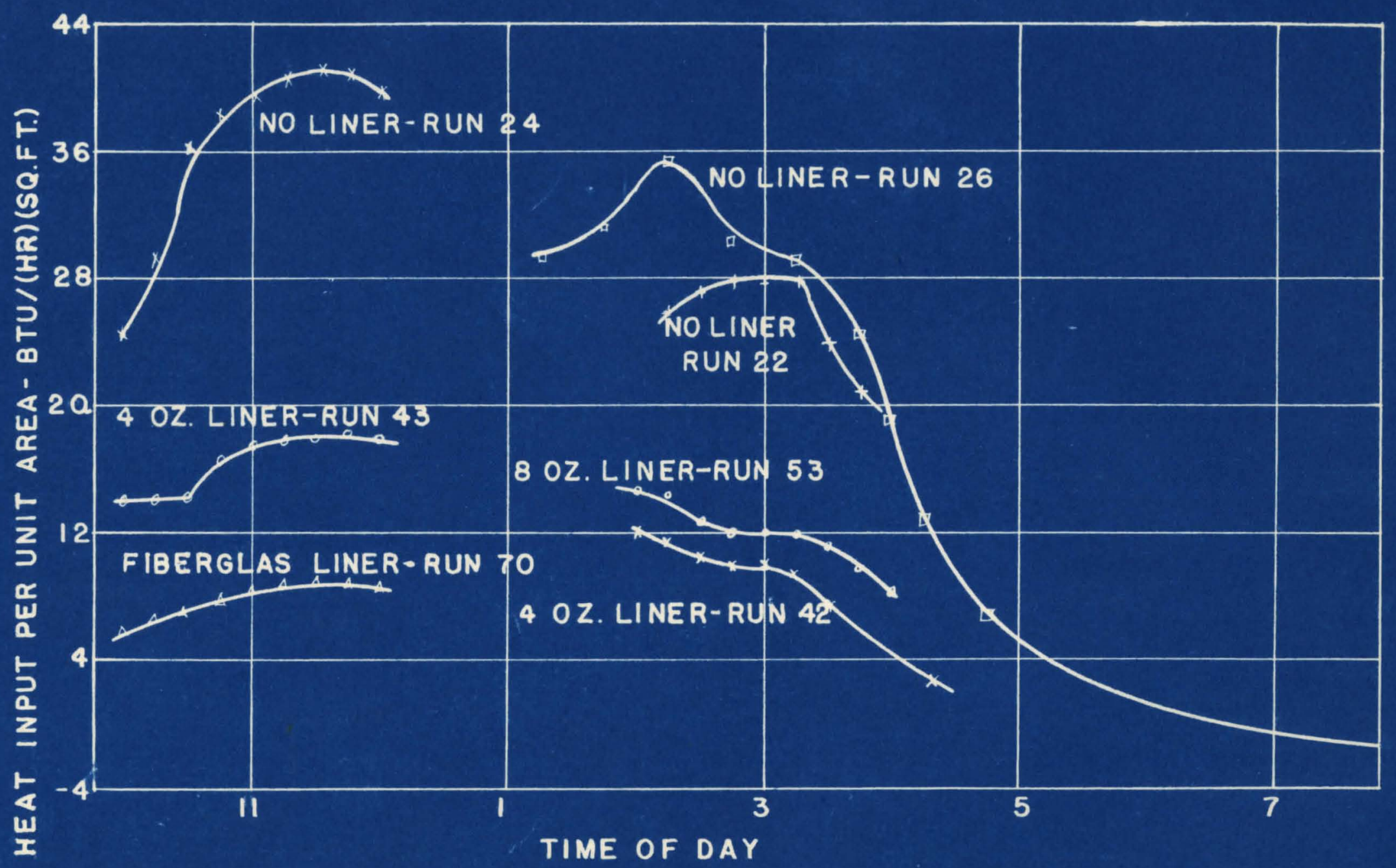

HEAT INPUT FROM SUN VERSUS TIME OF DAY

LARGE WALL TENT

FIGURE 10 
versus the tine of day for verious tent-liner combinations. This effective heat input was calculated using averge velues of coefficients from the deta of night and overcsst mus. Then, using $0, A$ and the measured $\Delta t$, the heat input, $q$, was calouleted from oquation (3), $q=v A \Delta t$, and the effective solar heat input celculated from the difference between the measured and calowlated heat input.

amount of radiation absorbed by the tent fabric varies with the intensity of the sun's radation. This intensity veries with the position of the sin in the sky (time of day), month of year, and condition of the sky. The influence of some of these variables on the hat requirements of the tent is observed by comparing the several runs shom in Figure 10. Runs 24, 43, and 70 were for a 100 per cent sunny day in the morning during February. Funs 22, 42, and 53 were for a 100 per cent sumy day in February in the afternoon. Run 26 wes for 100 per cent sunny day in April. It also is roticed that even though the sun wes shining with the same intensity on all the tents, it did not effectively heat them 211 by the same anount, but inversely to the anount of insulation In the form of Iiners that they contained. In the morning, for instance, the sun afectively added heat in the ratio of 40 to 16 to 8 in the three tents, 1.e., the sun increased the temperature difference in the tent with no liner five times as much as in the tent wh therglas liner. After the the tent fabric has ubsorbed the rediation from the sin, It re-radiates this heat either to tho outslde air and ground or to the inside surface. Then the tent contains a liner, especially a wite one with high reflectivity, the liner offers further resistance to the transfer of the sun's heat to the inside air and hence more is re-radiated to the outside, accounting for the lower effective heat frorn the sun in the tents with 


\section{Iiners.}

In examining the heat transfer charecteristies of various fabric combinations in tentage, as in the foregoing section, it was considered important to examine the data to determine whet properties or factors were responsible for the differences resulting from using the different liners. For instance, it was desired to know whether fabrics themselves contributed materially to the insulation, or whether the air filn resistance on each surface of a fabric was the controlling factor. Sxperience indicated that the latter should be controlling since the fabrics were thin and relatively good conducters.

The fact that weight, and to sone degree, the color and finishing treatment of the fabrics used as liners in tents hed little effect upon the overall coefficient or tewperature drops across them, was shown by the results from the $4.0 \mathrm{oz}$. cotton liner (white) and the $8.0 \mathrm{oz}$. cotton duck Iiner (0.D. 7). The overall coefflcient and teroerature drops across both of these liners were identical. This identity of results geve credence to the concept that the two afr filns constituted the main resistances, and that the weave, welght, and treatment of the febric had ilttle effect. This theory, of course, way not be rigorous when considering blanket type fabrios with greater thickmess and/or larger amounts of nap.

Further evidence of the controliling effect of the number of fsbric-to-air interfaces observed from plot of temperature differences between the iner and tent fabrics, the inside alr and the outside air (as ebsclssa) versus heat input. This plot 18 shown on Figure 11 where the lines in ascending order represent the elevetion of the followIng above outside alr temperature; (1) tent deck using $4.0 \mathrm{oz}$. Iner or 


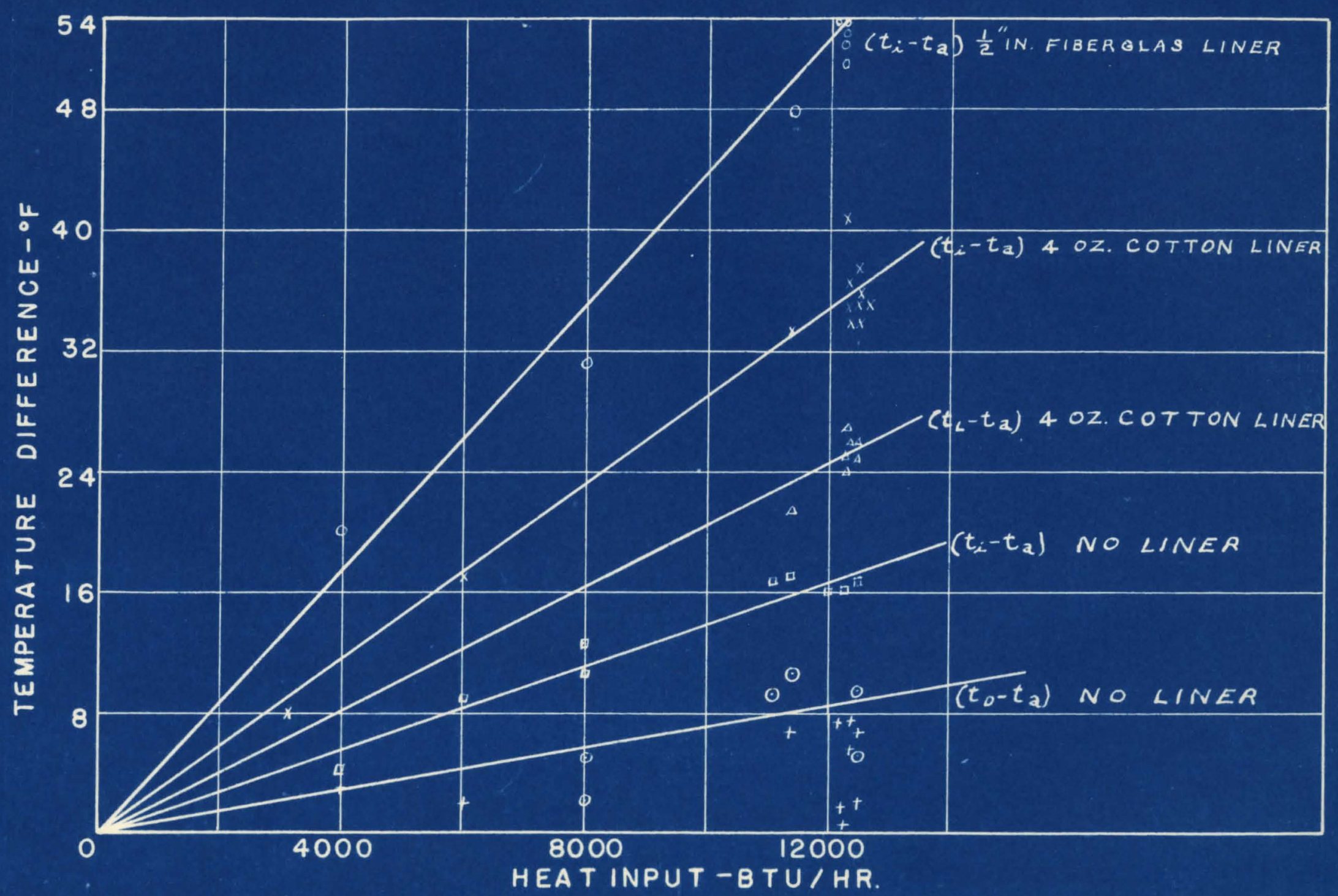

TEMPERATURE DIFFERENCE vS. HEAT INPUT FIGURE I I 
no Ilner, (2) Inside eir temereture using no liner, (3) Iiner deck using $4.0 \mathrm{oz}$. Iiner, (4) inslde air using $4.0 \mathrm{oz}$. 1iner, and (5) instde alr 1sing $1 / 2$ inch thick fibarglas 1tner. The number of alr films encountered between outside air and the points of measurent for the various lines on Figure 11 in ascending order are: (1) one, (2) two, (3) three, (4) four, and (5) six. It is seen from the plot thet the temperature differences for the tent and $4.0 \mathrm{oz}$. Iiner increase in the ratios of one, two, three, and four and, therefore, indicate an exact corresyondence with the number of air filns encountered.

From these results it was concluded that the neture of the fabric, be it the tent deck or the Ilner, has little effect on temperature drops end consequently little effect on the overall coefficients. It was further concluded thet eddition of nother Iiner, thereby increasing the number of fabrics to three and the number of alr films to six, would add a proportionate amount of insulation.

The fiberglas liner consisted of $1 / 2$ inch thick flberglas between two layers of $4 \mathrm{oz}$. wite cotton. This would give the flberglas liner four alr films, two for each layer of $4 \mathrm{oz}$. cotton. These four air flims plus the two for the tent fabric would give a total of six air films for the 1/2 inch thick fibergles as show in Figure 11. This would indicate thet the fiberglas offered no additional resistence to the heat flow but acted merely as spacer for the tivo shestings of $4 \mathrm{oz}$. white cotton.

Although the reletive nerits of varions liners was shown frow cheat transfer viemoint, the liner Hth the lowest coefficient, 1.e., fiberglas, had the greatest bulk and greatest welght. A nore reallstic valuation should include a practical study of the wight, bulk, and cost 
relationships for the various liners.

Each type of IIner has a specific wht and bulk and, for fixed conditions has a corresponding weight and bulk requirenent of fuel. If the sum of the welght or bulk of the liner and fuel is calculated, the liners may be compared and welght and bulk savings may be calculated. The cost of the fiel requlred with each liner also may be calculated and savinga determined.

For comparative purposes, the following conditions were assumed:

(1) A one-month field operation using large wall tents for which all tentige and fuel must be carried.

(2) Heating requirenents continuous for $2 / \mathrm{h}$ hours per day.

(3) 041 or gasoline heating units.

(4) Puel value: $15,000 \mathrm{BT} / \mathrm{Ib}$.

(5) Desired confort index of 1 ho.

(6) Outside air temperature $40^{\circ} \mathrm{y}$ and $20^{\circ} \mathrm{F}$.

The following weight and bulk values were found experimentally for liners for large wall tents:

\section{TABLE 2}

\section{WE ICHT AND BULK OF L MTERS}

Type itner Hght, Ibs. Bulk, ou. ft.

tio IIner

4.0 oz. Liner

8.0 oz. Liner

1/2 inch Fiberglas Liner

\section{0}

20

40

55
0 2 2 7

The nonogran of Figure 9 was used to determine the heating requirements in BW/ $\mathrm{Hr}$. for the above liners and for no liner at the 
temperature of $40^{\circ} \mathrm{F}$ and $20^{\circ} \mathrm{F}$. Using the fuel value factor of 15,000 $\mathrm{BTU} / 1 \mathrm{~b}$, the hourly fuel consumption was determined, and the hourly fuel. savings as compered to tent with no liner were caloulated. Using the weights of each liner, the hours of operation were detemined for the fuel welght saving to equal the corresponding liner relght. The volume of fuel saved per hour with the various liners and the days of operation necessary for bulk sevings to equal liner bulk were determined. The results of these calculations are summerized in Table 8.

From this tabulation it is apparent that eny of the liners become economical for operations of from 15 to 33 hours, and that further operation results in net savings of fuel waight. The tine required for the liner to return a saving is lessened at lower air teiperatures. Bulk savings are not quite so inpressive, however. At $40{ }^{\circ} \mathrm{F}$, only 3 days are required for the 4.0 oz. or $8.0 \mathrm{oz}$. Iiners to pay for themselves on bulk basts. This value is reduced to less then 2 days at $20^{\circ} \mathrm{F}$. The fiberglas Iiner having considerable ulk requires 8.9 and 5 deys to return a savings at alr temperatures of $40^{\circ} \mathrm{F}$ and $20^{\circ} \mathrm{F}$, respectively. It mey be concluded from these results that for operations of one week duration at these temperatures, the $4.0 \mathrm{oz}$. Inner would yleld significant sevings of both weight and bulk, wherees, the $8.0 \mathrm{oz}$. Iiner would not yield quite as much wight saving, and the fiberglas liner would not be practical on a b:lk saving basis.

Table 9 is a sumnary of fuel cost ( 5 cents per galion), fuel weight, frel bulk, total welght of fuel, liner, and contalner, totel bulk of fuel, Ilner, and container, and sevings of cost, weight, and bulk due to the use of a liner for one month's operation at temperatiras of $40^{\circ} \mathrm{F}$. and $20^{\circ} \mathrm{F}$ and for a confort index of 140 . The percent saving in cost, 
weight, and bulk at $40^{\circ} \mathrm{F}$ ngy be seen to be large with the fiberglas liner, high in cost and waght savings, and equal in bulk savings to the others. At $20^{\circ} \mathrm{F}$, however, the fiberglas 1 iner has savings of approximately 75 per cent for all three, whlle the $4.0 \mathrm{oz}$. and the $8.0 \mathrm{oz}$. liners have only 62 per cent savings. This represents an improvenent over the $4.0 \mathrm{oz}$, and $0.0 \mathrm{oz}$. IIners of abolt 20 per cent while they each represented en improvenent over a no liner operation of 62 per cent. For one month's operation at $20^{\circ} \mathrm{F}$, the 2,210 pounds saved by using fiberglas liner is considered significent.

Fron the Table 9 the values of fuel cost, total weight and bulk for one month's operation have been plotted agalnst overell heat transfer coefficients (see 1gure 12). Values of thase quantitias at a coeffielent 0.125 were calculated on a theoretical bagls and plotted on the greph to coralete the curves and to emphasize the minimum point in the bulk curves.

The curves for tght and cost decrease for decreasing values of the overall coefficient, whereas the bulk curve in both cases goes through ainimum. This minimum may be seen to move toward lower coefflclents for lower air temperature. The minimum of the bulk carve varies as conclitions change; for long operations, or lower temperatures, the minimum moves toward lower coefficients, whersas, for short operations and milder temperatures, the minimum moves towerd higher coefficients. In general, it mey be stated that at tertoeratures of $20 \mathrm{O}_{\mathrm{F}}$ to $40^{\circ}$ F, flberglas liners should be used on operations of several weeks or longer and the lighter 4.0 oz. Iiners shold be used on short operations. Likewlse, semi-pemanent tentage should be equipped wth Piberglas liners. The above anelysis wes made at mild temperatures and apecifically for a large wall tent, and, therefore, shoild not be assumed to hold true 


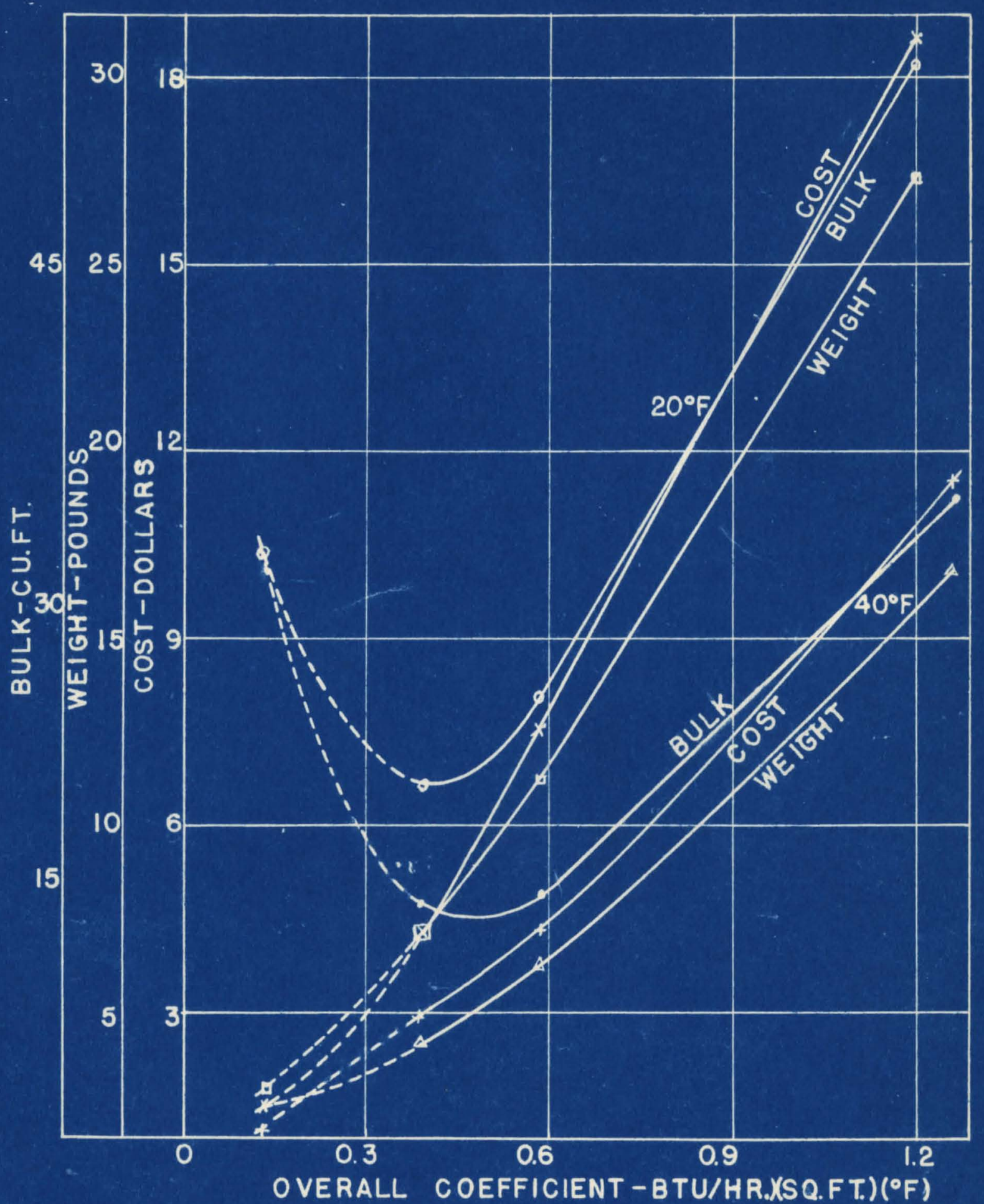

COST-BULK-WEIGHT OF FUEL AND LINER FIGURE 12 
for all tentage. A sinilar analysis, however, may be made for any tent and conditions desired with the use of the nomogran of Mgure 9. 


\section{PART II TGRPERATURE CONTROL IN TENTS - SUBMER PHASE}

Fron previous work of this neture, it was known that the flies which shaded the largest portion of a tent from direct solar radiation were the most effective in lowering the afr and fabric temperatures of the tent. (16) In accordence with these findings, ay 18 feet 1 ong and 28 feet wid with a hood on one end, as shown in Flgure 13, was designed. Since the large wall tents used in this test were pitched with the ridge Horth-South, It was necessary to have the hood only in the South end. A second Py was constructed wth the same dimensions as the first, but, of two layers of fabric, the outer fabric, 6.5 oz. oxford (O.D. 7), and the inner fabric, 4 oz. white cotton. This technique perinitted the meintenance of canourlage and at the sane tine took advantage of the better reflectivity of the white surface in reducing radiation from the $0.0 .7 \mathrm{fly}$ to the tent.

Thernocouples (attached to the inside surface of the tent by a gnall strip of adhesive tape) were located at the center of the decks, ends, side wals, and ground eloth. Thermocouples also were attached to the underside of the flles. When the tent was open, the inside air temperature wos messured with a themocouple. All of the themocouples were brought to selector switch outside the tent, making it unnecessery to enter the olosed tents during the runs. In these tests "closed" refers to a tent wth side wells pegged down and tightly tied at the corners and end-door openings. "Open" refers to the tent in which the s1de walls and ends are completely rolled up, leaving only the deck overhead. These two conditions give the extremes of tent usage, and any other partial opening of the tent would give intermediste results. 


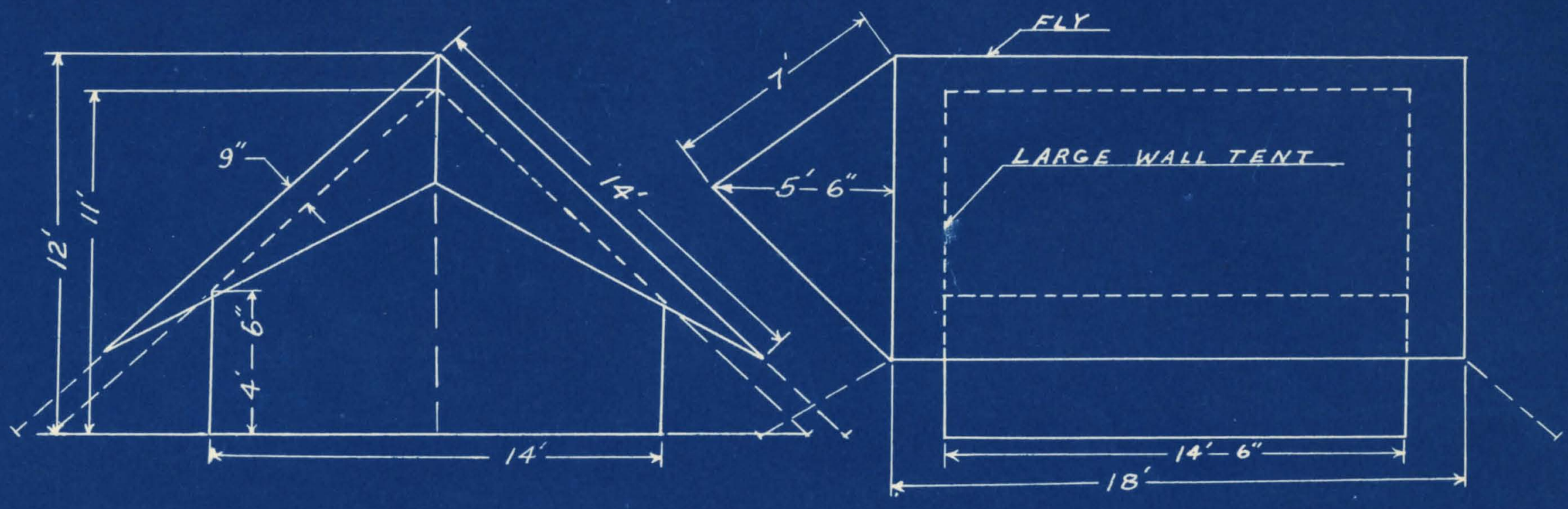

FLYNO. I SINGLE LAYER — 7.9OZ.TWILL, 0.D. 7

FLYNO. 2 DOUBLE LAYER 6.5 OZ. OXFORO,0.D. 7 (OUTSIDE LAYER) 4.0 OZ. WHITE COTTON (INSIDE LAYER) 3" AIR SPACE EXCEPT AT SEAMS

\author{
FIGURE 13
}

DETAIL OF LARGE, HOODED FLY 
Four series of runs were mede and the date are shown in Table 10 In the Appendix. In run 1, a comparison was made between a large wall tent completely alosed and unprotected, and large wall tent completely closed and protected by large, hooded, single layer fly. In run 3 compsrisons of the same structures were made with the tents open. In runs 2 and 4 , the effectiveness of the single layer fly was compared with that of the double layer fly with the tent closed (run 2) and the tent open (run 4).

A comparison of these dota 18 shown in Tebles 11 and 12 . In the compllations, the average air and surface temperatures for the various conditions are presented. The arerage inside surface temperatures are weighted avereges of the temperatures of the gide walls, ends, and decks of the tent, glving a temperature corresponding to single arface at a temperature such that the total radietion approximates that from the several tent surfaces. Therefore a conparison of the several tents, unprotected or protected by the elles, can be shom as temperature differences. These data are 1isted In Table 13. Fron this table it 1s observed that the instde air of the unprotected tent (closed) is 19 to $34{ }^{\circ}$ higher than the outaide air, wheress, the tent (olosed) protected by a single-layer fy is only 4 to $10^{\circ} \mathrm{F}$ higher than the outside air. Therefore, under these conditions of outslde alr (70 to $86^{\circ} \mathrm{F}$ ), the large, hooded, single layer $\mathrm{m}_{y}$ reduced the inside alr tempereture of the tent 25 to $24^{\circ} \mathrm{F}$ as compared to that of the unprotected $\mathrm{fly}$ and held the alr temperature of the tent within $10 \%$ of ambient air at all times. However, the confort of the individual in tent is not only a function of the inside air temperature but also a function of the enlasivity and temperature of the surfoce rediating to his body. A comparison of the surface temperatures reveals that the inside surface of the 
unprotected tent was 9 to $13^{\circ} \mathrm{F}$ higher than the inside air, wheress, in the tent protected by the otngle leyer fly, the inside surface terpereture wa only 1 to $4^{\circ} \mathrm{F}$ higher than the inside air temperature. This result neans that the occupant in the anprotected tent was exposed to a surface which was 20 to $37^{\circ} \mathrm{h}$ igher than the corresponding surface within the tent protected by alngle fabric $\mathrm{fy}$.

In the second series of runs a conparison was made between the double fabric fly and the single fabric fly. The double fabric fly reduced the inside air terazerature of the tent to within $6^{\circ} \mathrm{F}$ of the embient air temerature, 2 to $4^{\circ} \mathrm{F}$ lower than the inside air in the tent protected by the single fabrio $\mathrm{fly}$. It also gave an inside surfece tenperature 1 to $3^{\circ}$ F lower than the single layer fly. In these runs, the air temperatures remained in the seventies and althoigh good results were obtalned with the double layer fIy, even better results would be expected at the higher temperatures.

With the tents open the Inside air approsched the ambient air when aither hy was used end was within $4^{\circ} \mathrm{F}$ of ambient wen no fiy wes used. However, the inside surface temperature was found to be 15 to $20 \%$ higher in the unprotected tent then in the tent protected by a fly.

Figure 34 is a plot of alr and surface tamperatures versus time for one portion of $\min 1$, with Ine (dotted) for the double layer Iy calculated from the results of run 2. This curve shows the effect of the various liners when the outside air tamperature and wind velocity conditlons were those that prevelled in this run. All of these data were taken on a clear, 100 per cent sunny day with the wind velocity less than $10 \mathrm{mph}$ at all times. 


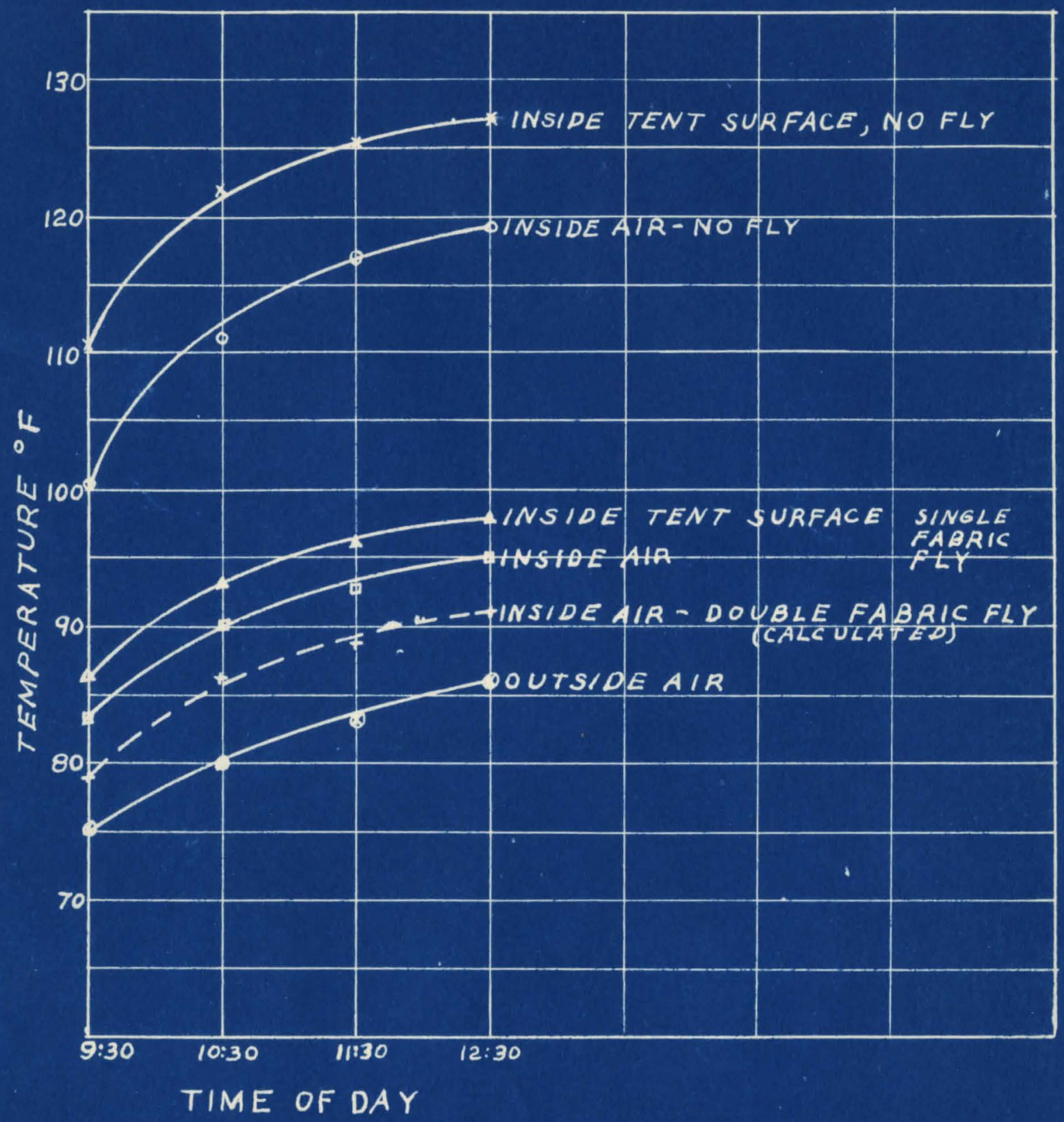

FIGURE I4

TIME VERSUS AIR AND SURFACE TEMPERATURE LARGE HOODED FLIES 


\section{PART III ARCTTC SHELTER DESIOR}

Turther consideration of the problems and results of experience in Alaskan tests diring the winter of $1946-47$ showed the necessity of several modifloations in the design of the Arctic shelter frame. Since the shelter was to be rehiclemportable, the nembers should have meximum length of 12 feet. Acoordingly the design of the Arctic ahelter frame was revised so that it fulfilled this specifiestion. This chenge resulted in alight change in the helght and contour of the frame but did not effect the essentials of the design.

St111 further considaration of the design led to several additional changes, and the drawings were agein revised to include these new 1deas. This final revision is show in the drawings on pages 63 through 69. It declded that trangportation on the smallest amu vehicle avillable for this use would necessitate shorter length of the nembers. Therefore new naxdmu of 8 feet in length was set and the structure was again revised. Reduclng the length of the I-bean arches made it necessary to change the plecemont of the purlins, which connected adjacent ribs, and to add an additional purien to each slde of the frane. Theretore the new design has 8 side purlins instead of 6 (drawing no. 1). This change In the maxdmum length of the members also necesaitated breaking the lower verticals in the end sections at their center and using wing nut clamp to fasten the two sactions together.

A seoond change in the design was the use of an entrance 4 feet Wide in the ends, reducing the number of verticals to 4 instead of 6 (drawIng no. 3). In order to ettach the Prbric cover and prevent its excessive flapping during wirds, a horizontal tube identieal to the verticals was 


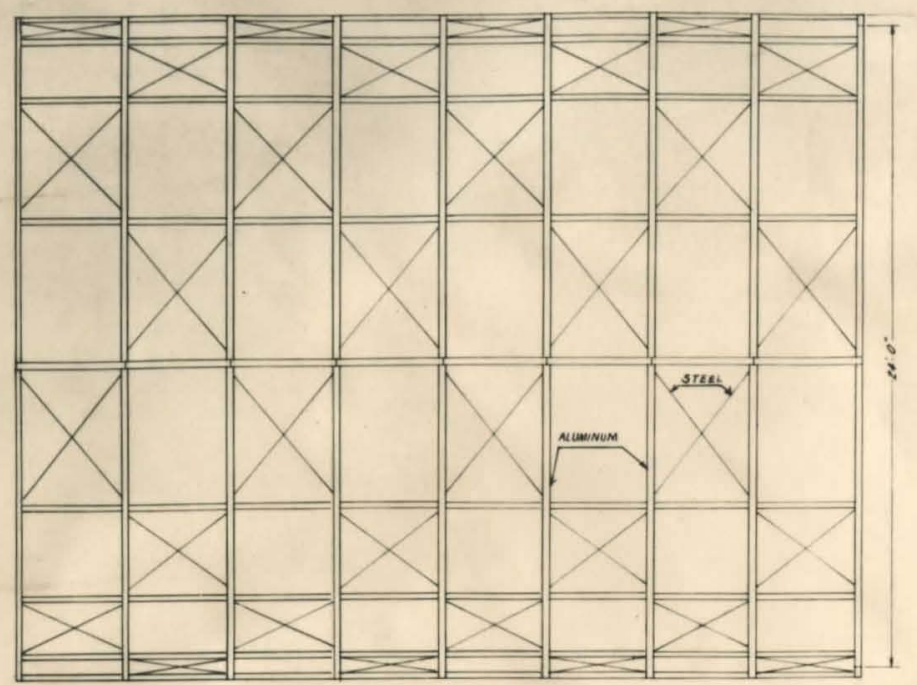

PLAN VIEW

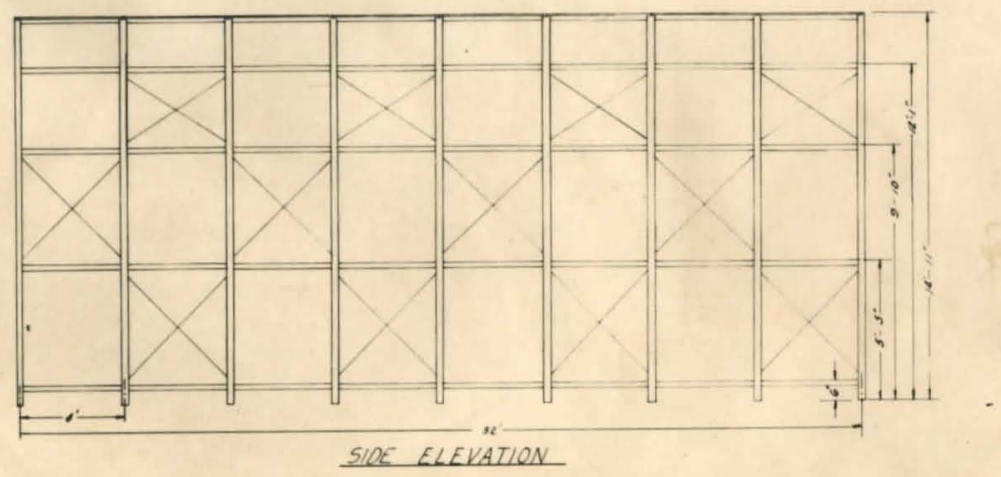

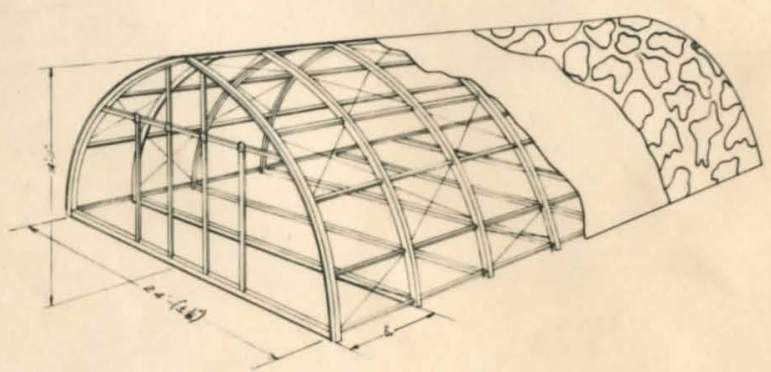

$\frac{\text { ARCTIC SHELTER }}{\text { FRAME DESIGN }}$

SCALE $\because$.

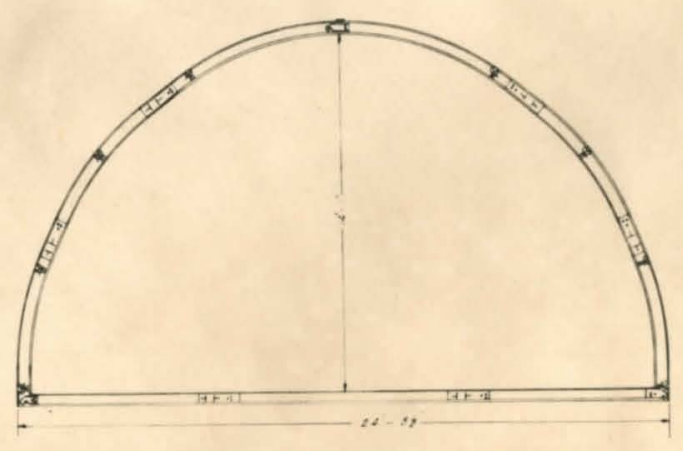

END ELEVATION

FIGURE I 5 


$$
(6)
$$




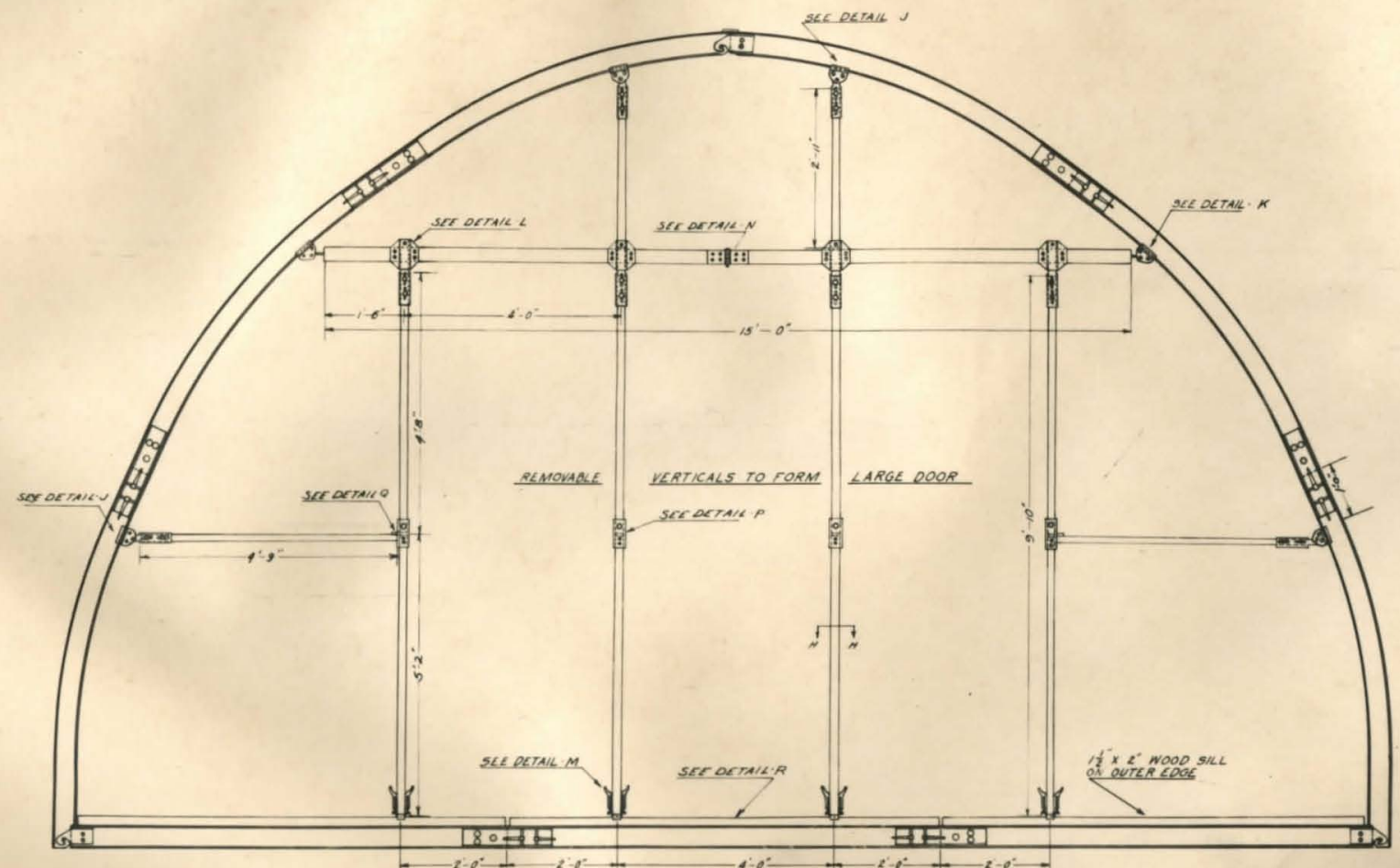

END SECTION LAYOUT
BILL OF MATERIALS

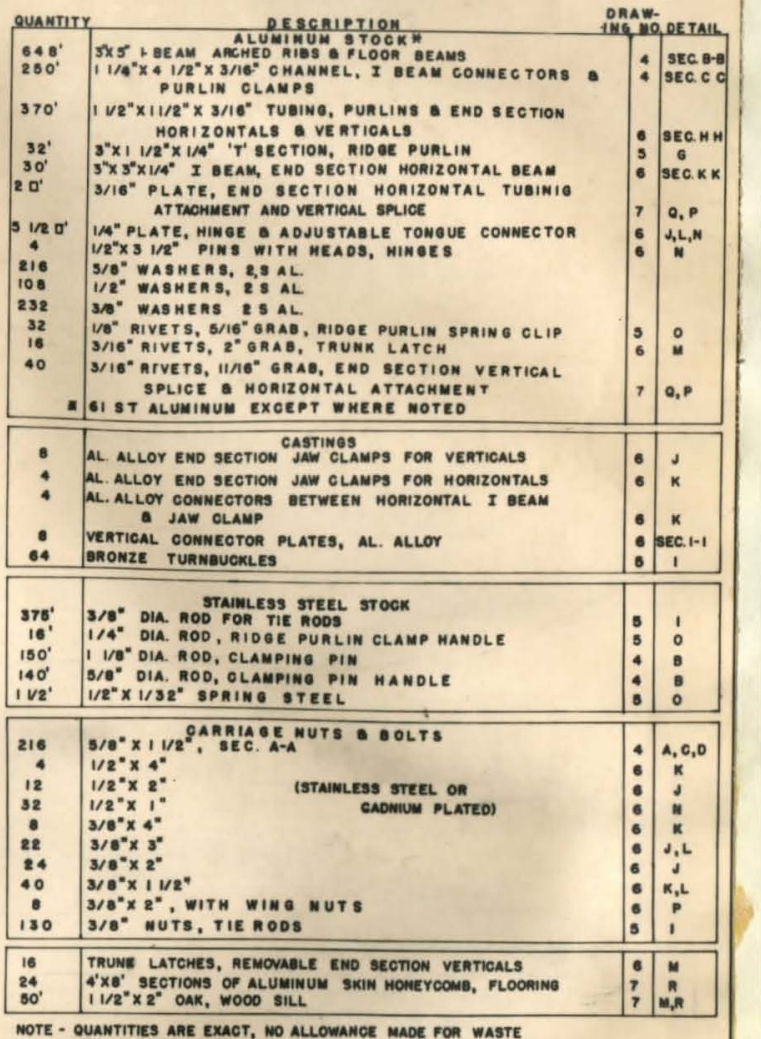

MOTE - OUANTITIES ARE EXACT, NO ALLOWANOE MADE FOR WASTE 


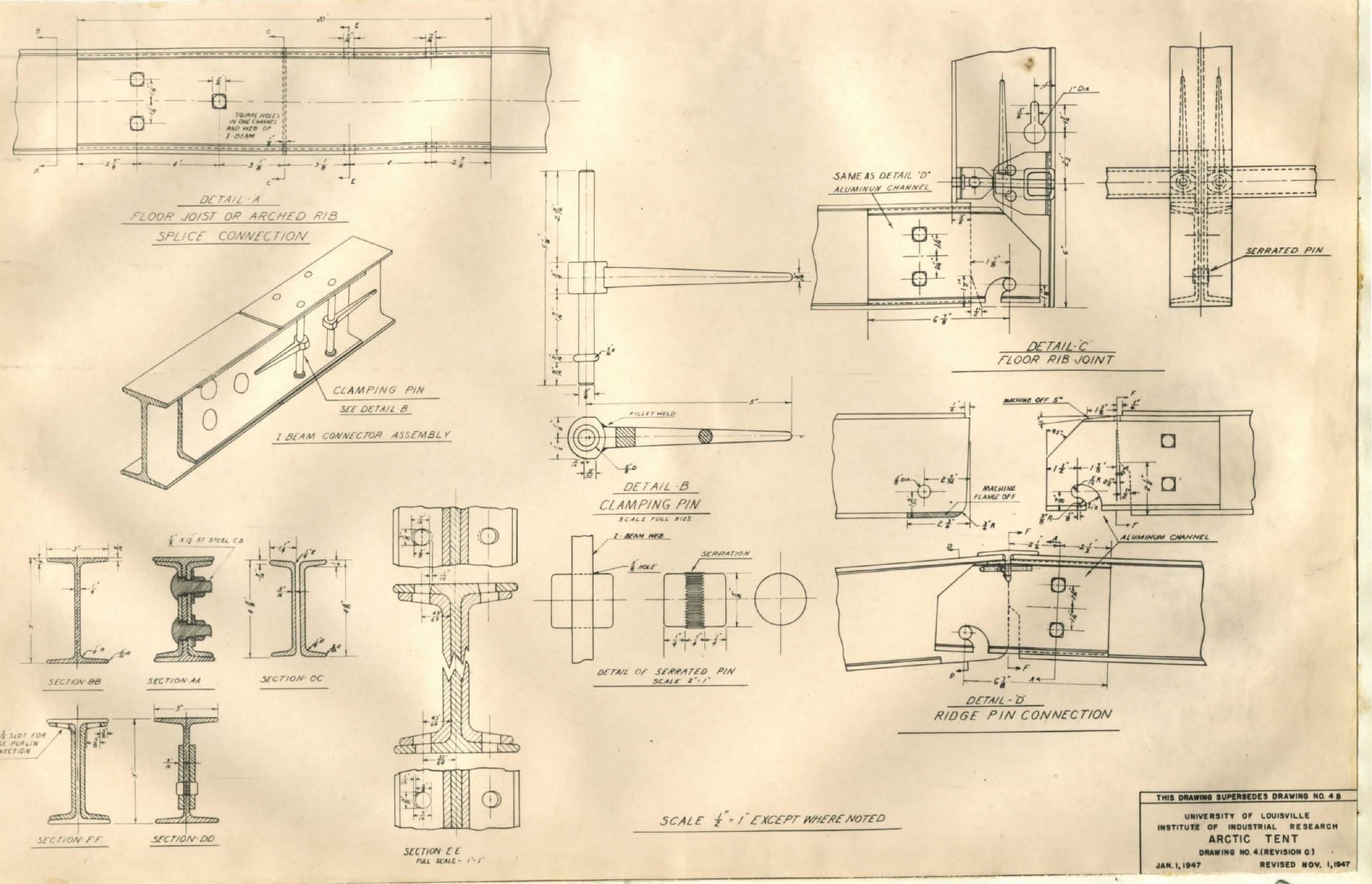




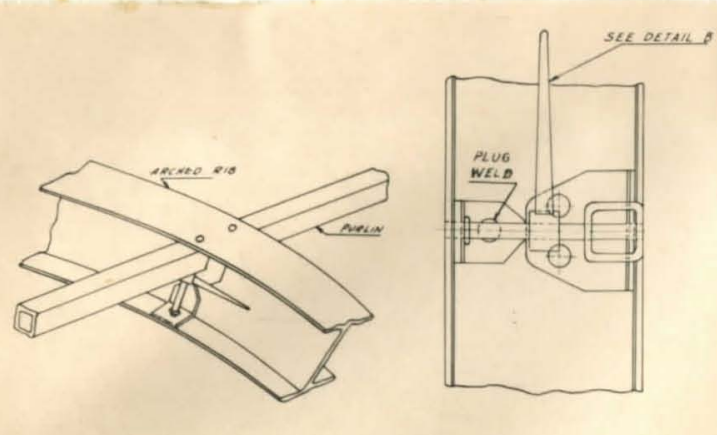

.
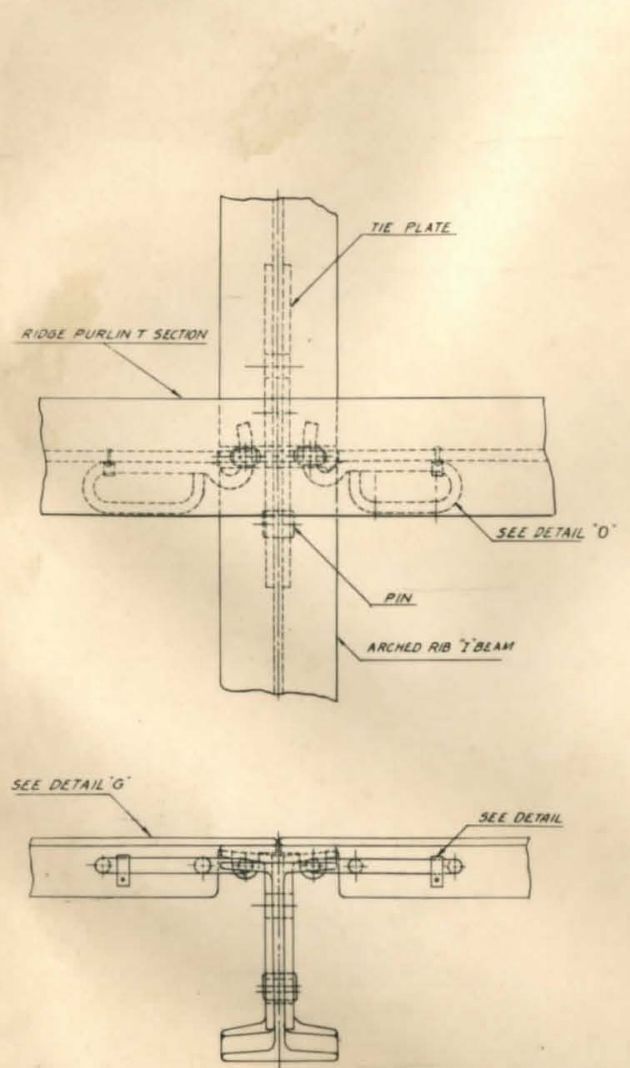

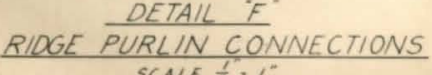

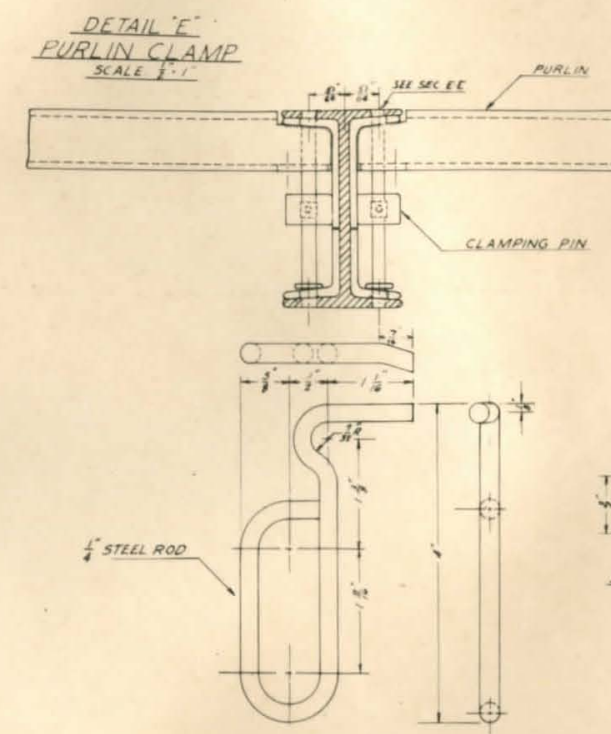

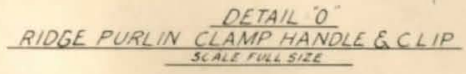

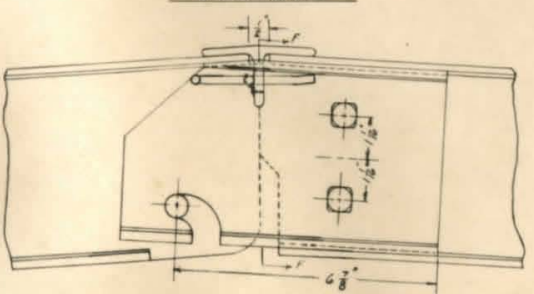

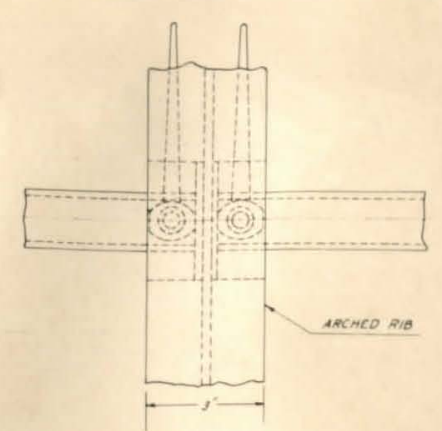
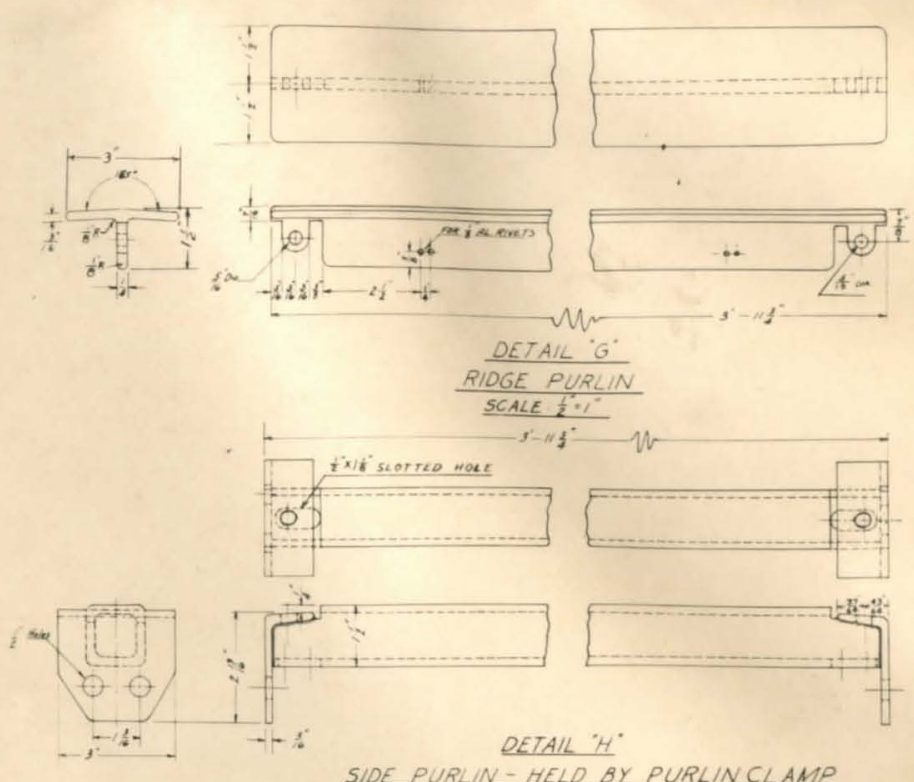

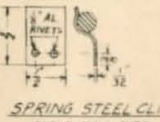

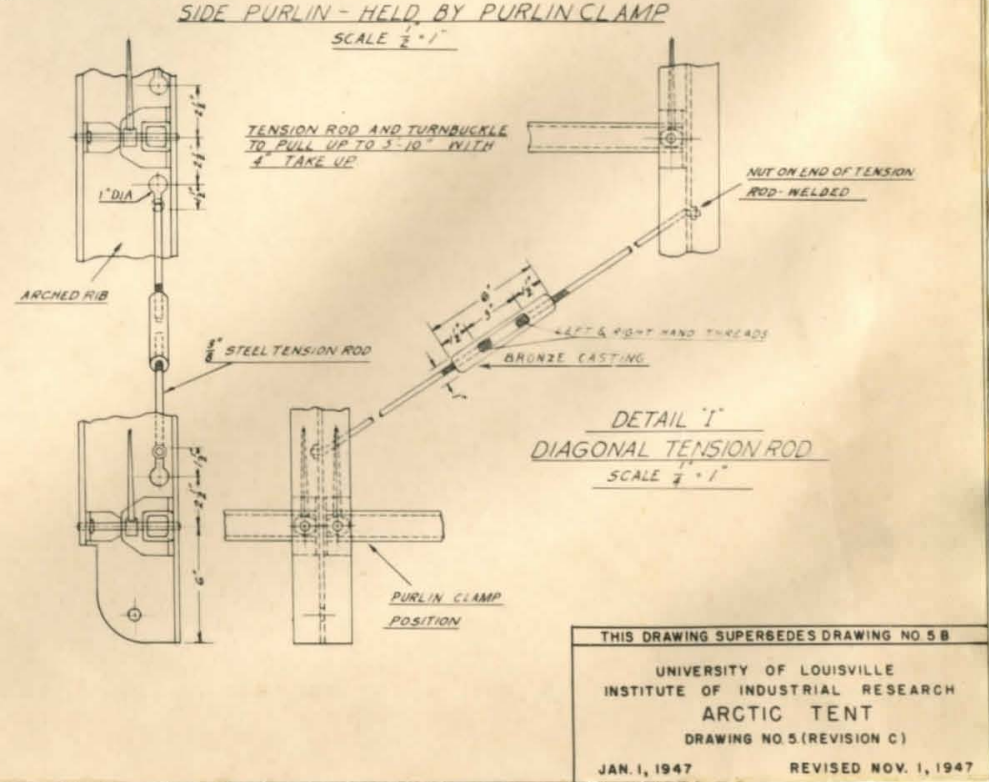




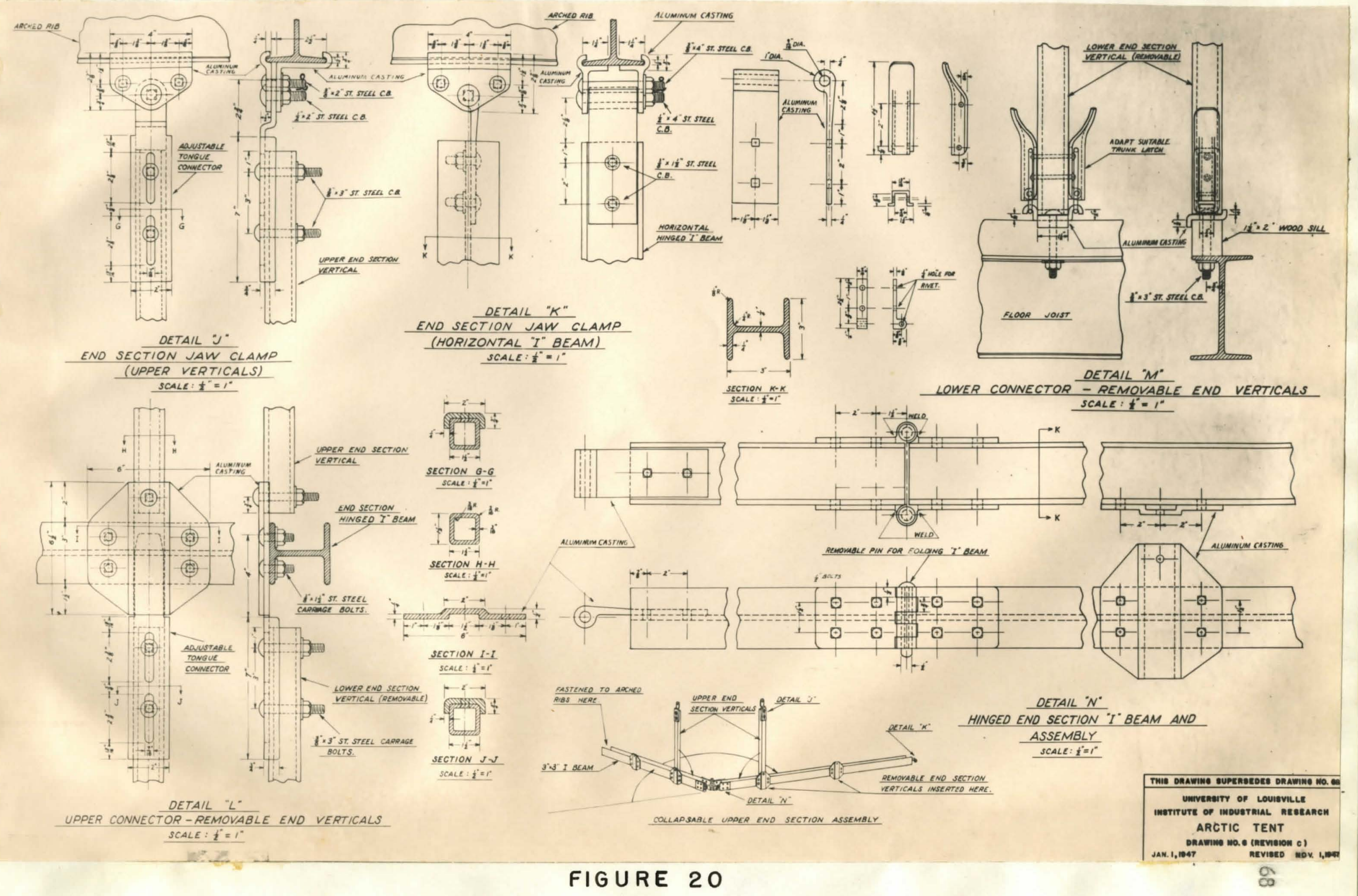




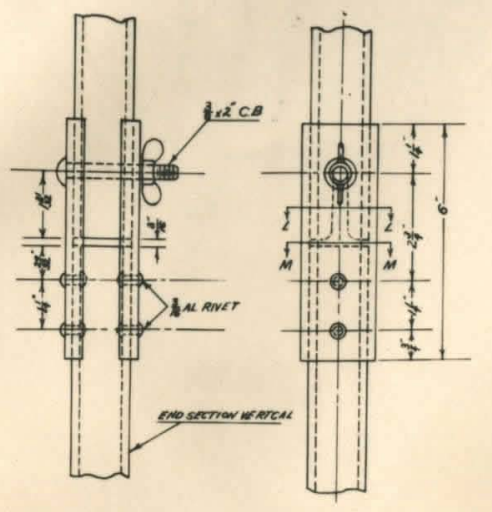

DETAIL.P

END SECTION VERTICAL SPLICE CONNECTION

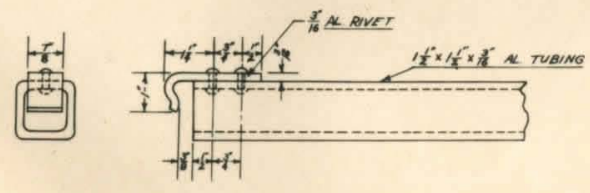

DETAIL-Q

END SECTION HORIZONTAL

ATTACHMENT

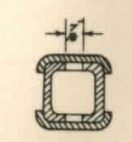

SECTION.L.

$\frac{t}{1+\infty}$

का

secrion in.

(24 FLOOR SECTIONS AEO'D PER 32 FOOT SHELTER)
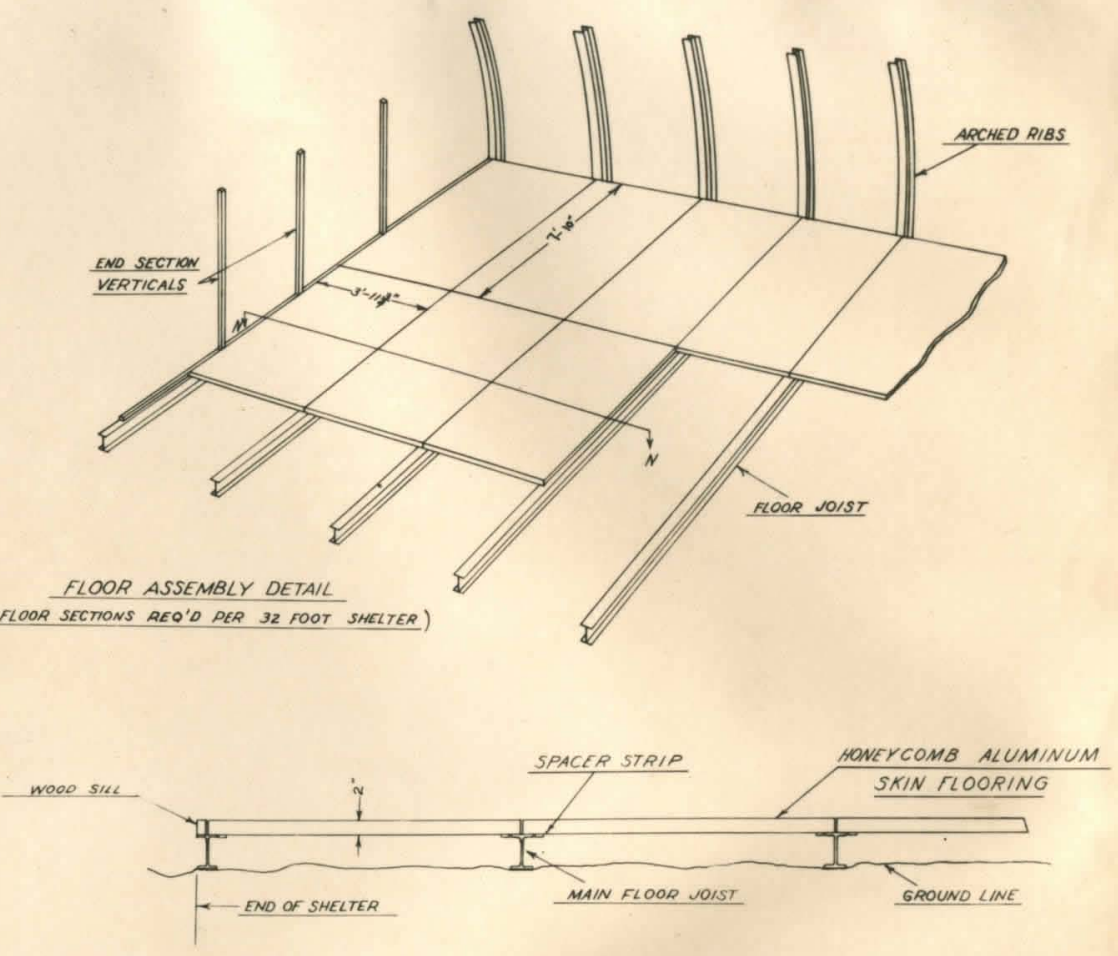

SECTION - N.N

CAOSS SECTIONAL VIEW OF FLOOR JOIST

ANO PANELS

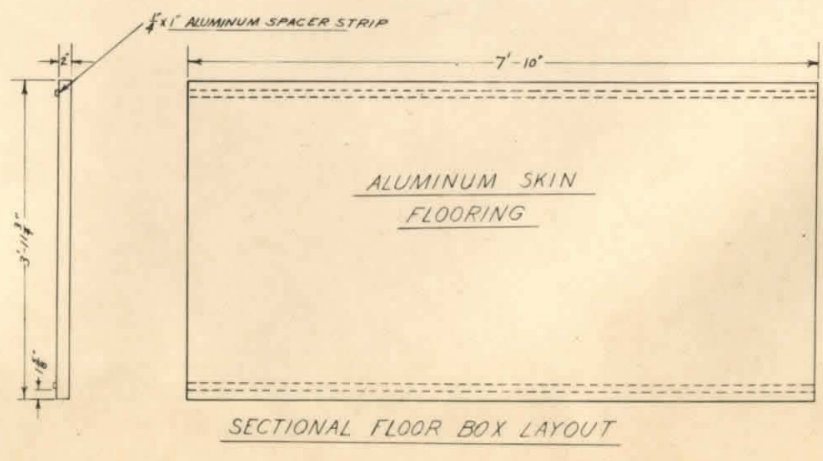

DETAIL-R

SECTIONAL FLOORING

\begin{tabular}{|l}
\hline THIS ORAWIING SUPERSEOES DRAWING NO $7 \theta$ \\
UNIVERSITY OF LOUISVILLE \\
INSTITUTE OF INDUSTRIAL RESEARCH \\
ARCTIC TENT \\
ORAWING NO T(REVISION C) \\
REVISED N OV I, 1947 \\
JAN 1. 1947
\end{tabular} 
placed on each side of the end section between the large door vertical nember and the arched rib.

The severe cold of the Arctic regions mokes it necessary to wear heavy arctic wittens whlle orecting the sheltor. The threading of nuts on bolts entailed considerable diffeulty and it was decided to replace nuts and bolts by other types of fasteners wherever possible in the frame design. Originally the floor rib joint and I-bean ridge joint were connectad by nut, and bolt gusset plate. The hook and pin arrangement shom in draring 4 was devised for use at these connections. The hook consists of an aluminum chemel 8 inches long permanently attached to one bean by nuts and boits rith hook extending beyond the end of the bean. The other beam contains serreted steel pin which slips into the slot of the hook. When one bean is rotated 90 degrees this pin (slightly offset) tightens agatnst the hook and makes a rigld joint.

The I-bean splice in both the arched ribs and floor were conneoted by a bolted channel plate. This same chennel was used permanently bolted to one section of the beam (drawing no. 4). A hole wes drilled through the top and bottom Ilange of both the I-beam and channel and a pin (with o collar) slipped into the hole in the upper flanges. To perait this operation, the two holes were elongated toward the flange edge. The pin had a lever attrached at the center so that it could be turmed 90 degrees wth a can action, forcing the channel tightly against the Imbean. The compliceted purlin clamp was replaced by the same lever-pin srrangement described above (drawing no. 5).

The new type of hook-pin connection used at the ridge did not permit the ase of the original purlin connection. Instead the web of the ridge purlin $T$ section was notched so that it fltted into an oblong hole 
In the rlange of the channel and was held in place by a clamping pin. The new boltless fasteners described above were first made wh cardboard templets. Fron these the practicality of the particular fastener was ascertained and working dimensions determined. Then full scale aluminum models were constructed end the fastener was mede to work properly before being considered complete.

Discusaions with the namueturers of this shelter frame led to further changes in the method of menufacture of sone of the parts. It was decided to use castings for all connector plates in the and section shown on drating no. 6 and to substitute wolding instead of machining wherever possible. These revised drawings of the Arctic shelter frame (shom on pages 63 through 69) Include detailed descriptions of the following nodifications: meximum length of nembers, 8 feet; 4 foot entrance in the end section; horizontal support in the end section; book and pin fasteners at the I-beam splices and side purlin comections; oblong slotted connections for the ridge purling and alumima castings for end section connectors. 
SUMEARY AND CONCLUSTONS 
PART I TEMPEEATURE CONTROL IN TENTS - WATTAR PHASE

From the results of this study, Iiners were found to be an effective means of reducing heat loss from tents. The comparativa values of the heat loss coefficients gave good indications of the value of the liner-tent combinations. Over the range of wind velocities encountered in these tests a tent with no liner was found to have a coefflcient of heat loss of $1.26 \mathrm{BTU} /(\mathrm{Fr})$ (sq. ft.) $\left({ }^{\circ} \mathrm{F}\right)$ whereas the coefficients for the $4 \mathrm{oz}$. white cotton conventional, the $4 \mathrm{oz}$. white cotton low profile liner, the 8 or. $0 . D .7$ cotton 1 iner, and the $1 / 2$ inch thick fibergles liner were $0.58,0.58,0.58$, and $0.37 \mathrm{BTJ} /(\mathrm{Hr}),(\mathrm{sq} . \mathrm{ft}).\left({ }^{\circ} \mathrm{F}\right)$, respectively.

From the confort reletions, it wes found that the comfort of an occupant in a tent was function of the aversge sinface temperature to which he was exposed as well as the inside air temperature. A comfort index equal to the sum of inside air temperature and the average inside surface temperature afforded a satisfactory comparison for various linertent combinations.

It was found that the color, weight, and meteriel of the liner had Ilttle effect on the heat loss. The amount of resistance to heat now was a function of the number of air films encountered, and double or triple layers of fabries ware considered the best means of insulating tent.

Also, low profile liners that allow sufficient head room should be superior to conventional liners since they give nore favorable temperature distribution in the tent and have less weight and bulk.

The use of these liners afford significant savings in the cost, weight, and $b: a k$ of fuel required for fleld tent operation. The greater 
the Insulating value of the 11ner. the groater 2 the peroentage of saving. 
PART II TFMPLRATURE CONTEOL IN TQNPS - SUMAER PHASE

From the results of this work it seens highly desirable to use large flles similar to the hooded flles used in this test; the flies showld completely shade the tent from direct solar radiation. The double Ieyer ny improved the comfort of the tent but not sufficiently to justify the aditional ight and menufacturing expense. It seens preferable to nake the fly of a meterial lighter than $12.29 \mathrm{oz}$. duck sinoe it need not be subjected to stresses severe se the tent itself.

The use of this type of large, hooded fly appeers to be the linit of the anount of cooling that can be given a tent by elther fly or Iner as long as it is necessary to have the outside surface of canouflage color. It has been show that the effectiveness of the fly can be increased sonewhat by the use of an inner surface which has a low emissivity, for example, such as the double layer fly or light colored under surface. However, these methods have not show sufficient lmprovement to warrant their recomentation.

The solution to the problem of sumer phese temperature control of tents may be resolved into the following techniques in order of liportance: (1) Open tent for air tempereture reduction, (2) 1arge, hooded fly for alr and interior surface temperatire reduction, (3) Inner fly surface and/or inner tent surface of low enissivity for radiation reduction. The combination of (1) and (2) produces an interior tent tenperature only sllghtly above ambient air temperature with reasonably low radiation to the occupants. 
PART III ARCTIC SHELTER DESIGN

The Arctic shelter frame hrs been redesigned suggested by experience in the Arctic. The frame can easily be erected whilo wearing Arctic mittens since operations requiring the threading of nuts on bolts heve been replnced by boltless fasteners. The length of individual members of the frame has been redueed to a minum of 8 feet making the shelter vehicle-portable. It now contains 24 foot entrance wth renovable verticals for a 16 foot entrance. It is believed that this design fulf111s the necessary requirments for general purpose Arotic shelter frame. 
LITERATURE CITLD 
(1) Barnes, H.R., Harvin, E.L., and MIIliams, O. K., "Improved Design of Tents and Tentage Ratorial, 1945-46" lst edition, University of Louisville Institute of Industrial Research, Loulsville, 15.1946

(2) Barnes, W.R. and associates, "Text1le Serles Report No. 15 Tent Design and Construction" United States Department of Commerce 1946

(3) Raber and Hutchinson, "Panel Heating and Cooling Anslysis", lat edition, Volume I, Jokn wlley and Sons, New York 1947

(4) Barnes, W.R., Harvin, R.L., Filliams, G. W., and Gerhard, E.R., "Improved Design of Tents and Tentage Materiels July 1946 - June 2947" University of Louisville Institute of Industriel Research, Louisville, $\mathrm{ky}, 1947$ pp. 85-135

(5) Barnes, W. R., Harvin, R.L., and HIllams, G.W., "Inproved Design of Tents and Tentage Msterial, 1945-46" lat edition, iniversity of Louisville Institute of Industrial Research, Louisville, ky. 1946 pp. $156-158$

(6) Ibid, p. 158

(7) Hackey, C.0., and Wright, L.T. Ir., "Heating, Plping and A1r Conditioning" Volume 141942 pp. $750-760$

(8) Houghton, F.C., Te.1mity, S.I., Cutberlet, C., and Erom, C.J., "Heating, Piping and Air Conditioning" Volume 14 1942 pp. 69-74

(9) Kaber and kutchinson, "Panel Heating and Cooling Analysis", Ist edition, Volurae.I, John rilley and Sons, New York, 1947 pp. 58-59

(10) Ib1d, pp. 61-62

(11) Ibid, p. 65

(12) 1bid, p. 65

(13) ibid, pp. 66-67

(14) ibid, pp. 75-78 
(15) MeAdsms, N.H., "Heat Transmission" 2nd edition McCraw-Hill Book Co. New York 1942 pp. 6-10

(16) Barnes, W.R., Harvin, R.L., Wulliams, G. $\pi_{0}$, and Gerhard, E.R., "Improved Design of Tents and Tentage Materials July 1946 - June 1947" University of Louisville Institute of Industrial Research Louisville, Ky. 2947 pp. 1-22

(17) Alloock and Jones, "The Nomogram" lst edition SIr Issac PItman and Sons London 1932 pp. 40-43

(18) 1bid, pp. 50-53 
AFPARDIX 
Absorptivity

Ares

Area Factor in Radiation

Coefricient of Heat Transfer, Conduction

Coefficient of Heat Transfer, Individual

Coefficlent of Heat Transfer, Overall

Coefficlent of Heat Transfer, Radiation

Conduction

Buistuity

Baissivity Pactor in Radiation

Heat How, Cuentity

Heat How, Rate

Radlation

Reflectivity Factor

Speciflo Heat

Temperature

Temperature, Absolute

Temperature, AIr Inside

Tenperature, Alr catside

Temperature, Average Surface

Temperature, Equivalent AIr

Temperatire, Foor

Temperature, Ground

Temperaturs, Liner Fabric

Temperature, Mean Rndiant $\propto$

A

sq. $f t$.

A

ho

h

$\mathrm{Brv} /(\mathrm{Hr}).(\mathrm{sq} . \mathrm{ft}).\left(^{\circ} \mathrm{F}\right)$

$*$

U

*

$h_{p}$

*

c

e

F

Q

BTU

$q$

$\mathrm{BTU} / \mathrm{Hr}$.

$\mathbf{r}$

${ }^{2}$

$\mathrm{C}_{\mathrm{P}}$

$\mathrm{BTU} /(1 \mathrm{~b}).\left({ }^{\circ}\right)$

t

op

T

of

$t_{1}$

op

$t_{\mathrm{a}}$

ast

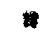

$t_{a b}$

*

.

$t$

*

$t_{\mathrm{s}}$

t.

mat

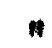

1)

a 
LIST OF SWAOLS (CONTINURD)

Name

Symbols

Units

Temperature, Tent Fabric

$t_{\mathrm{D}}$

T

Tempersture, Surface

$t_{\mathbf{a}}$

Teuperature, Surroundings

tb

n

Time

$\theta$

Hr.

Transmisgivity Factor

t.

Velocity

V

H. $/ \mathrm{Hir}$.

Weight

W

1 bs 
DERIVATION OF NOMOCRAN

For the construction of the nomogrem relating comfort index, outslde air, and the types of 11 ners and tents, equation (23) is broken down into the following product or sum equations by introducing two new paraneters $\mathrm{C}$ and $\mathrm{K}$ :

$$
\begin{aligned}
& K=\frac{a}{4} \\
& c=x \\
& T=2 t_{a}+c
\end{aligned}
$$

Equetion (32) could be represented by nomogrem of three perallel ines and equations (30) and (31) by a "2"chart, two lines being parallel and one diagonal: These nowograms could be constructed by a reletively simple geometric method since they are all stralght lines. However, the more general method of nonogram construction, using deterninants, was applied to this particular problen. (17)

The range of variables were fixed as follows:

$$
\begin{array}{ll}
\mathrm{T} & 0 \text { to } 160 \\
t_{\mathrm{a}} & 0 \text { to } 70 \mathrm{oF} \\
\mathrm{q} & 0 \text { to } 80,000 \mathrm{BTU} / \mathrm{Hr} . \\
\mathrm{u} & 0 \text { to } 1.5 \mathrm{Bm} /(\mathrm{Hr} .)(\mathrm{sq} . \mathrm{ft} .)\left({ }^{\circ} \mathrm{F}\right) \\
\mathrm{A} & 0 \text { to } 1,200 \mathrm{sq} \cdot \mathrm{ft} .
\end{array}
$$

The value of $h_{18}$ was asmued equal to 2.35 , an average found from previous runs to be representative.

Equation (32) was put in the form,

$$
T-2 t_{a}-C=0
$$


The constructional deterninent in functional form for equation (32a) was,

$$
\left|\begin{array}{ccc}
-\delta_{1} & m_{1} f_{1}(x) & 1 \\
0 & -\frac{m_{1} m_{3}}{m_{1}+m_{3}} f_{2}\left(t_{2}\right) & 1 \\
\delta_{3} & m_{3} f(c) & 1
\end{array}\right|=0
$$

where $\delta_{3}=\frac{m_{3}}{m_{1}} \delta_{1}$, this equation became,

$$
\left|\begin{array}{ccc}
-\delta_{1} & m_{1} T & 1 \\
0 & -\frac{m_{1} m_{3}}{m_{1}+m_{3}} 2 t_{n} & 1 \\
\delta_{3} & -m_{3} c & 1
\end{array}\right|=0
$$

where $\mathcal{S}_{1}$ and $\delta_{3}$ are distances between perallel lines and $m_{1}$ and $m_{3}$ are scele moduli.

The with of the nomogram for equation (32a) was chosen as 4 inches, giving,

$$
\delta_{1}+\delta_{3}=4
$$

The length of the scales were set at 6 inches and the scale moduli were determined using the limits of the range of each variable. The values of $\delta_{1}$ and $\delta_{3}$ wore than calculated, giving, $\delta=2$ and $\delta=2$, when $m_{2}=m_{3}=0.0375$.

The resultant determinent for plotting the nowogrem then becane,

$\left|\begin{array}{ccc}-2.0 & 0.0375 \mathrm{~T} & 1 \\ 0 & 0.0375 \mathrm{t}_{\mathrm{a}} & 1 \\ 2.0 & -0.0375 \mathrm{c} & 1\end{array}\right|=0$


The nomogram has three parallel lines, 2 inches on center, each With scale fector of 0.0375 , wth the $c$ line inverted.

Equation (31) was put in the form,

$\mathrm{x} W-\mathrm{C}=\mathrm{O}$

The constructional determinent in functional forn for this equation (31a) $\mathrm{ras},(18)$

$$
\left|\begin{array}{ccc}
0 & m_{1} f(c) & 1 \\
\frac{\delta_{3} \frac{f(w)}{f(w)+1}}{\delta_{3}-m_{3} \frac{f(w)}{f(w)+1}+m_{3}} & 0 & 1 \\
\delta_{3} & -m_{3} f(x) & 1
\end{array}\right|=0
$$

Treating this determinent as before, the form used for plottins became,

$$
\left|\begin{array}{ccc}
0 & -0.0375 c & 1 \\
4(-0.0375)\left(\frac{W}{W+1}\right) & 0 & 1 \\
4 & 0.09 \mathrm{~K} & 1
\end{array}\right|=0
$$

The nomogram resulting from equation (3la) was plotted with the $C$ line colnclding with the $C$ line of the flrst nomogram and with the $\mathrm{K}$ line parellel to it at a distance of 4 inches to the right. The IIne was plotted in terms of $\mathrm{U}$ as a diagonal between the $\mathrm{C}$ and $\mathrm{X}$ IInes. Equation (30) was put in the form,

$$
\frac{q}{A}-K=0
$$


The constructional determinent in functional form for equation (30a) is the same as equation (36). The equation used for plotting the final nomogram became,

$$
\left|\begin{array}{ccc}
0 & 7.5 \times 10^{-5} q & 1 \\
4\left(7.5 \times 10^{-5}\right)\left(\frac{1}{A+1}\right) & 0 & 1 \\
4 & -.09)\left(\frac{1}{A+1}\right)+0.09 & 1
\end{array}\right|
$$

The nomogrem resulting from oquation $(30 \mathrm{a})$ was plotted wth the $\mathrm{X}$ Iine coinclding with the $\mathrm{K}$ IIne of the second nomogrem and the 9 Ine parallel to It at a distance of 4 inches to the right. The A IIne was plotted diagonally. 
TENT NO. 1 DATE $2-2 E-47$ WEATHER Pverosist

TYPE TENT Large Wall - No Liner - Ground Cloth

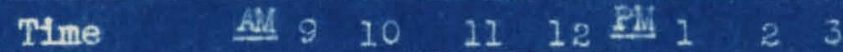

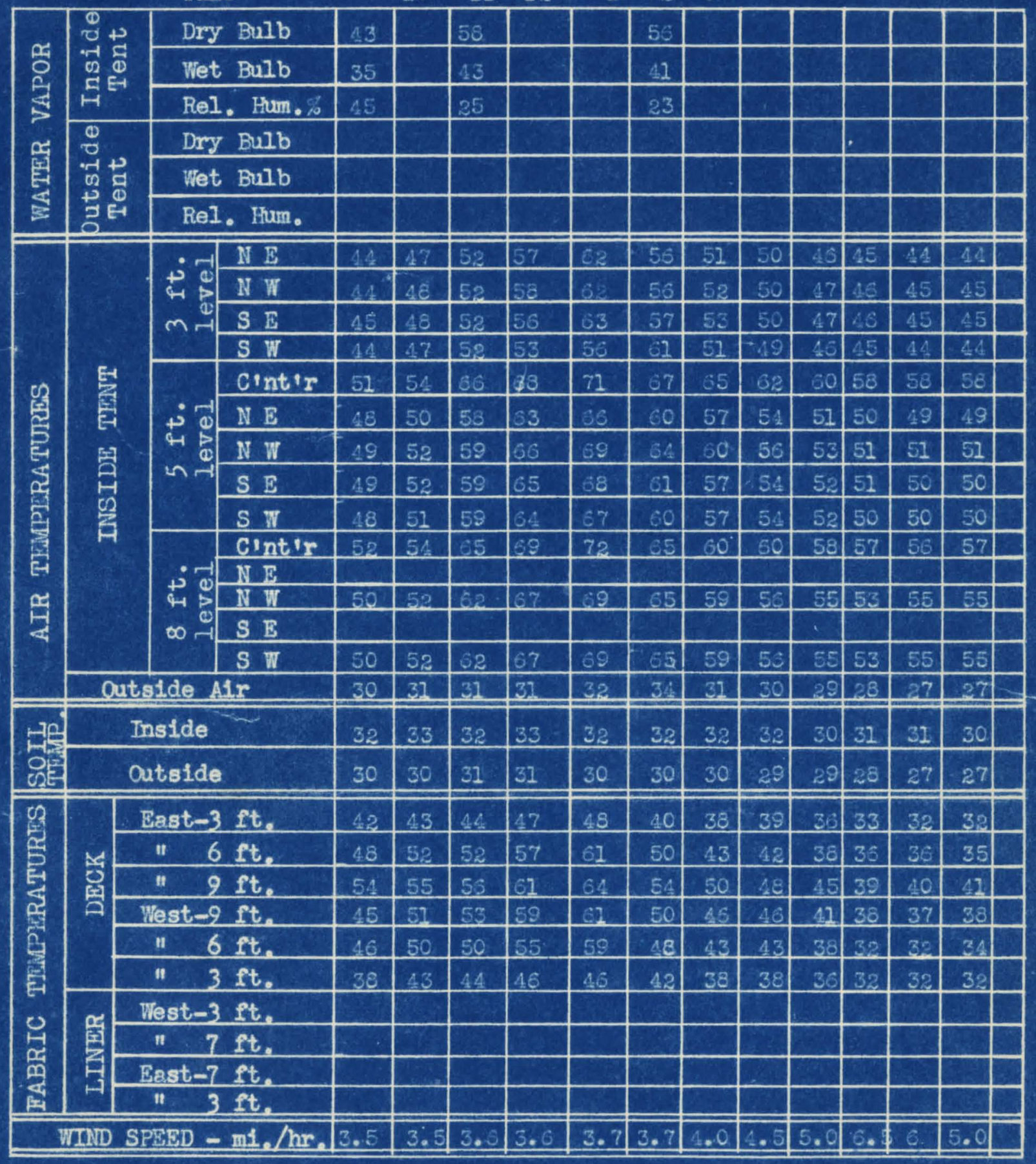

\section{SAMPLE DATA SHEET


TABLE 3 LIST OF TEST RUNS - TYPE AND MEATHER

\begin{tabular}{|c|c|c|c|c|c|c|c|}
\hline $\begin{array}{c}\text { Test } \\
\text { No. }\end{array}$ & $\begin{array}{l}\text { Date } \\
1947\end{array}$ & $\begin{array}{c}\text { Tume } \\
\text { of } \\
\operatorname{Dan} \\
\text { (Approx.) } \\
\text { C.S.T. }\end{array}$ & $\begin{array}{l}\text { Ground } \\
\text { Cloth }\end{array}$ & $\begin{array}{l}\text { Heat } \\
\text { Input } \\
\text { BTU/Ft }\end{array}$ & $\begin{array}{c}\text { Outside } \\
\text { Atr } \\
\text { Texp. }\end{array}$ & $\begin{array}{c}\text { Relative } \\
\text { Humidity } \\
\%\end{array}$ & $\begin{array}{l}\text { Wnd } \\
\text { Vel. } \\
\text { mph }\end{array}$ \\
\hline
\end{tabular}

LARGE WALI TMNT - NO LINER

\begin{tabular}{|c|c|c|c|c|c|c|c|c|}
\hline & $\begin{array}{l}2 / 13 \\
2 / 12 \\
2 / 24 \\
2 / 25 \\
2 / 26 \\
2 / 27 \\
2 / 28 \\
3 / 4 \\
3 / 7 \\
3 / 12 \\
4 / 11 \\
3 / 13 \\
3 / 3 \\
2 / 21 \\
2 / 19 \\
4 / 8 \\
2 / 19 \\
4 / 8 \\
2 / 19 \\
2 / 21 \\
3 / 5 \\
3 / 10 \\
4 / 9 \\
2 / 27 \\
3 / 12 \\
4 / 3 \\
4 / 3 \\
3 / 12 \\
3 / 10\end{array}$ & 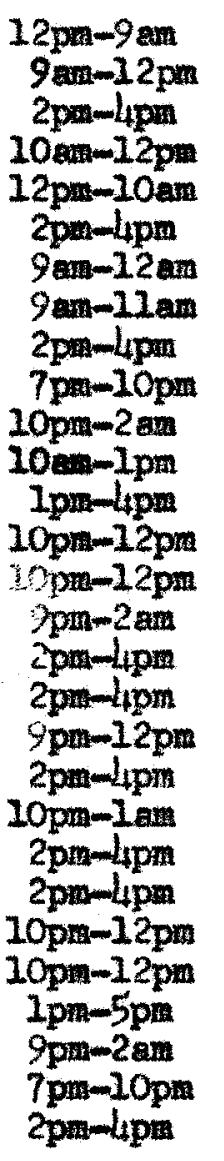 & $\begin{array}{l}12 \\
n \\
n \\
n \\
\text { None } \\
12 \\
n \\
n \\
n \\
n \\
n \\
n \\
n \\
\text { None } \\
n \\
n \\
n \\
n \\
n\end{array}$ & $\begin{array}{r}12,500 \\
12,500 \\
11,380 \\
12,260 \\
12,260 \\
11,120 \\
11,750 \\
12,200 \\
11,100 \\
12,550 \\
9,000 \\
8,000 \\
8,700 \\
7,930 \\
8,100 \\
6,000 \\
6,000 \\
5,840 \\
6,000 \\
6,450 \\
4,000 \\
4,000 \\
4,000 \\
4,000 \\
0 \\
0 \\
12,500 \\
6,450\end{array}$ & $\begin{array}{l}24-40 \\
29-43 \\
28-29 \\
27-30 \\
26-31 \\
37-38 \\
35-37 \\
33-40 \\
42-44 \\
47-50 \\
44-50 \\
43-46 \\
32-34 \\
29-34 \\
23-27 \\
48-49 \\
35-36 \\
32-34 \\
34-40 \\
52-53 \\
49-52 \\
40-42 \\
24-40 \\
28-34 \\
42-47 \\
59-63 \\
50-52 \\
47-50 \\
52-53\end{array}$ & $\begin{array}{l}66 \\
14 \\
71 \\
- \\
\overline{42} \\
33 \\
60 \\
53 \\
50 \\
\overline{100} \\
70 \\
60 \\
- \\
= \\
= \\
60 \\
59 \\
32 \\
= \\
66 \\
39 \\
72 \\
58 \\
64 \\
35\end{array}$ & $\begin{array}{l}- \\
5.5 \\
3.5 \\
4.0 \\
4.7 \\
1.8 \\
3.3 \\
5.7 \\
0.0 \\
0.0 \\
2.3 \\
5.6 \\
4.2 \\
3.9 \\
1.3 \\
3.9 \\
6.0 \\
0.7 \\
0.4 \\
1.2 \\
-1 \\
3.9 \\
4.4 \\
6.9 \\
1.7 \\
1.7 \\
0.0 \\
2.4\end{array}$ & $\begin{array}{l}\text { Hight } \\
25 \\
0 \\
0 \\
\text { Night } \\
100 \\
97 \\
22 \\
0 \\
\text { Night } \\
\text { Night } \\
0 \\
43 \\
66 \\
100 \\
\text { Night } \\
100 \\
14 \\
44 \\
100 \\
\text { Night } \\
100 \\
0 \\
100 \\
100 \\
\text { Night } \\
\text { Might } \\
100\end{array}$ \\
\hline
\end{tabular}

LARCE WALE TENT - 4 OZ. WHITE COTTON L MER

\begin{tabular}{|c|c|c|c|c|c|c|c|c|}
\hline $\begin{array}{l}30 \\
31 \\
32 \\
33 \\
34 \\
35 \\
36 \\
37 \\
38\end{array}$ & $\begin{array}{l}2 / 12 \\
2 / 12 \\
2 / 13 \\
2 / 25 \\
2 / 25 \\
2 / 26 \\
2 / 24 \\
2 / 21 \\
2 / 27\end{array}$ & $\begin{array}{c}10 \mathrm{am}-12 \mathrm{pm} \\
10 \mathrm{am}-12 \mathrm{pm} \\
12 \mathrm{pm}-10 \mathrm{am} \\
10 \mathrm{am}-12 \mathrm{pm} \\
10 \mathrm{am}-12 \mathrm{pm} \\
12 \mathrm{pm}-10 \mathrm{am} \\
2 \mathrm{pm}-1 \mathrm{pm} \\
10 \mathrm{am}-12 \mathrm{am} \\
2 \mathrm{pm}-4 \mathrm{pm}\end{array}$ & $\begin{array}{c}12.29 \\
n \\
n \\
n \\
n \\
n \\
n\end{array}$ & $\begin{array}{r}12,500 \\
12,500 \\
12,500 \\
12,260 \\
12,260 \\
12,260 \\
11,300 \\
7,930 \\
8,000\end{array}$ & $\begin{array}{l}29-43 \\
29-43 \\
24-40 \\
27-30 \\
27-30 \\
26-31 \\
28-29 \\
29-34 \\
37-38\end{array}$ & $\begin{array}{l}40 \\
73 \\
82 \\
- \\
= \\
= \\
71 \\
52 \\
40\end{array}$ & $\begin{array}{l}- \\
3.5 \\
4.5 \\
3.0 \\
5.5 \\
4.2 \\
4.7\end{array}$ & $\begin{array}{l}0 \\
\text { Night } \\
\text { Night } \\
0 \\
\text { Night } \\
\text { Might } \\
0 \\
66 \\
100\end{array}$ \\
\hline
\end{tabular}


TABLE 3 (CONTTHUED)

\begin{tabular}{|c|c|c|c|c|c|c|c|}
\hline $\begin{array}{l}\text { pest } \\
\text { Ho. }\end{array}$ & $\begin{array}{l}\text { Date } \\
1947\end{array}$ & $\begin{array}{c}\text { Muse } \\
\text { of } \\
\text { Run } \\
\text { (Approx.) } \\
\text { C.S. } T_{.} .\end{array}$ & $\begin{array}{l}\text { Ground } \\
\text { Gloth }\end{array}$ & $\begin{array}{l}\text { Heat } \\
\text { Input } \\
\text { BTO/tix }\end{array}$ & $\begin{array}{c}\text { outside } \\
\text { Alr } \\
\text { Temp. }\end{array}$ & $\begin{array}{c}\text { Relative } \\
\text { Humidity } \\
\&\end{array}$ & $\begin{array}{l}\text { Wind } \\
\text { Vel. } \\
\text { mph }\end{array}$ \\
\hline
\end{tabular}

IARGE WALL TENT - 4 OZ. WHITE COTPON LINER

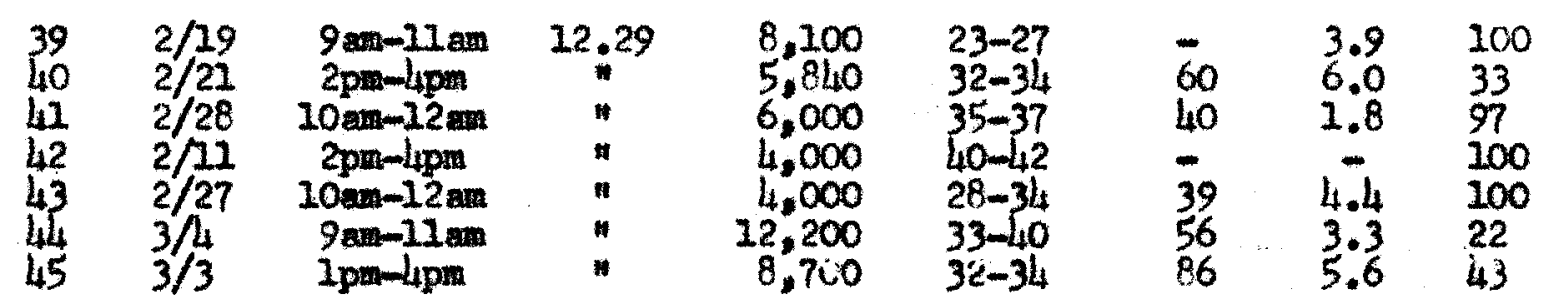

LARGE VILI TENT - LOW PROPIII 4 O2. VITTE COTTON L INER

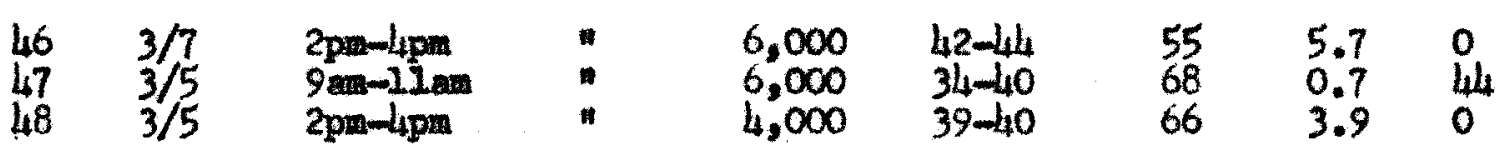

LAROE WALL TENT - 8 OZ. 0.D. 7 COTTON L MNER

$\begin{array}{ccccccccc}49 & 2 / 12 & 10 \mathrm{am}-12 \mathrm{pm} & * & 12,500 & 29-43 & 40 & - & 0 \\ 50 & 2 / 12 & 10 \mathrm{am}-12 \mathrm{pm} & * & 12,500 & 29-43 & 73 & - & \text { N1ght } \\ 51 & 2 / 13 & 12 \mathrm{pm}-10 \mathrm{am} & * & 12,500 & 24-40 & 82 & - & \text { N1ght } \\ 52 & 2 / 19 & 10 \mathrm{am}-12 \mathrm{am} & * & 8,100 & 23-27 & * & 3.9 & 100 \\ 53 & 2 / 11 & 2 \mathrm{pm}-4 \mathrm{pm} & * & 4,000 & 40-42 & - & - & 100\end{array}$

LAHOS WALL TENT - 1/2 INCH FIBEGGLAS LDNER

\begin{tabular}{|c|c|c|c|c|c|c|c|}
\hline $\begin{array}{l}2 / 25 \\
2 / 25 \\
2 / 26 \\
3 / 4 \\
2 / 24 \\
3 / 12 \\
2 / 21 \\
3 / 13 \\
3 / 5 \\
2 / 21 \\
3 / 20 \\
3 / 3 \\
3 / 5 \\
3 / 5 \\
2 / 27 \\
2 / 28 \\
2 / 27\end{array}$ & 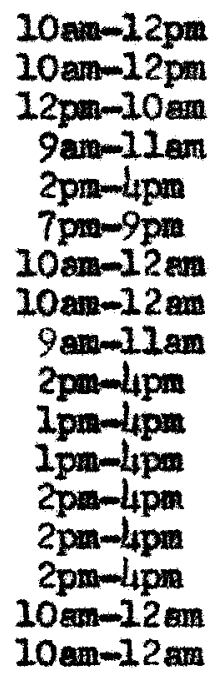 & $\begin{array}{l}" \\
": \\
\text { None } \\
12.29 \\
\text { None } \\
12.29 \\
\text { None } \\
12.29 \\
n \\
n \\
n \\
n\end{array}$ & $\begin{array}{r}12,260 \\
12,260 \\
12,260 \\
12,200 \\
11,380 \\
12,550 \\
7,930 \\
8,000 \\
6,000 \\
5,840 \\
6,450 \\
8,700 \\
4,060 \\
6,000 \\
4,000 \\
4,000 \\
4,040\end{array}$ & $\begin{array}{l}27-30 \\
27-30 \\
26-31 \\
33-40 \\
28-29 \\
47-50 \\
29-34 \\
43-46 \\
34-40 \\
32-34 \\
52-53 \\
32-34 \\
39-\sqrt{10} \\
42-44 \\
37-38 \\
35-37 \\
28-34\end{array}$ & $\begin{array}{l}- \\
\overline{5} \\
58 \\
77 \\
50 \\
52 \\
100 \\
68 \\
60 \\
32 \\
83 \\
66 \\
55 \\
42 \\
33 \\
39\end{array}$ & $\begin{array}{l}5 \\
5 \\
0 \\
3 \\
5\end{array}$ & $\begin{array}{l}0 \\
\text { Night } \\
\text { Hight } \\
22 \\
0 \\
\text { Night } \\
66 \\
0 \\
44 \\
33 \\
100 \\
43 \\
0 \\
0 \\
100 \\
97 \\
100\end{array}$ \\
\hline
\end{tabular}


TABLE 3 (CONTINUED)

\begin{tabular}{|c|c|c|c|c|c|c|c|c|}
\hline $\begin{array}{l}\text { Test } \\
\text { No. }\end{array}$ & $\begin{array}{l}\text { Date } \\
2947\end{array}$ & $\begin{array}{c}\text { Time } \\
\text { of } \\
\text { Ran } \\
\text { (Approx.) } \\
\text { C.S. T. }\end{array}$ & $\begin{array}{l}\text { Ground } \\
\text { Cloth }\end{array}$ & $\begin{array}{c}\text { Heat } \\
\text { Inqut } \\
\text { BTV/Fr }\end{array}$ & $\begin{array}{c}\text { Outside } \\
\text { Alr } \\
\text { Temp. }\end{array}$ & $\begin{array}{l}\text { Relative } \\
\text { Shunidity } \\
\Phi\end{array}$ & $\begin{array}{l}\text { Wind } \\
\text { Vel. } \\
\text { mph }\end{array}$ & \& Sun \\
\hline
\end{tabular}

SQUAD TENT $4-1945$ - NO LTHER

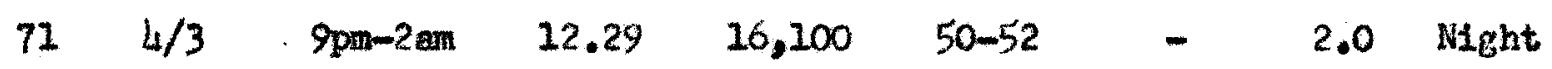

SQUAD TEMT $16-1945$ - 4 OZ. WHTE COTTON LINER

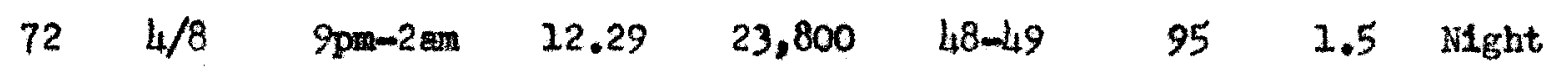

SQUAD TENT H-1945 - LOW PROFIHE 4 OZ. WHITE COTTON

73. 4/21 9pm-2am 22.29 $24,100 \quad 44-50 \quad-\quad 0.0$ Hight

SQUAD TEMT M-1945 - LOW PROFTLS 1/2 DNCH FIBERGLAS LTNRR

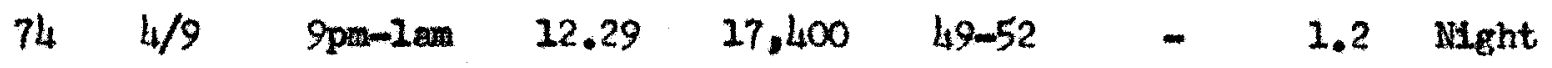

SQUAD TENT IL-1945 - LOH PRORTLE 4 OZ. WHITS COTTON LTNER

\begin{tabular}{|c|c|c|}
\hline $\begin{array}{l}5 / 5 \\
5 / 6\end{array}$ & $\begin{array}{r}90 m-12 a \\
12 a m-2 a m\end{array}$ & \\
\hline
\end{tabular}

LAROE WALL TENT - NO LIAER

$\begin{array}{lllllll}77 & 5 / 5 & 9 \text { pm-2 an } & \begin{array}{c}12.29 \\ \text { and }\end{array} & 12,000 & 46-55 & -\end{array}$ 
TABLE 4 AIR, GROUND, AND FABRIC TEAPERATULES

\begin{tabular}{|c|c|c|c|c|c|c|}
\hline \multirow[b]{2}{*}{$\begin{array}{c}\text { Test } \\
\text { No. }\end{array}$} & \multicolumn{6}{|c|}{ Avorage Temperatures ${ }^{\circ} \mathrm{F}$} \\
\hline & $\begin{array}{c}\text { cutside } \\
\text { Ground } \\
t_{g}\end{array}$ & $\begin{array}{c}\text { Oatside } \\
\text { Alr } \\
t\end{array}$ & $\begin{array}{l}\text { Inside } \\
\text { Atr } \\
t_{1}\end{array}$ & $\begin{array}{c}\text { Tent } \\
\text { Pabric } \\
t_{D}\end{array}$ & ${ }^{t_{L}} \mathrm{Lner}$ & $\begin{array}{c}\text { Ground } \\
\text { cloth } \\
\text { (Floor) } \\
t_{f}\end{array}$ \\
\hline 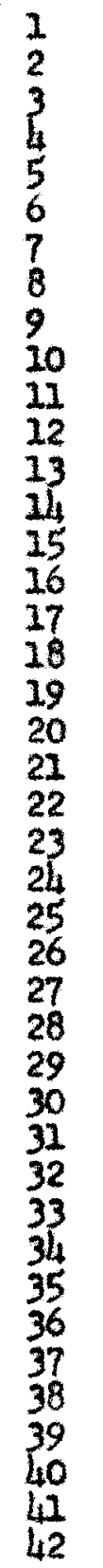 & $\begin{array}{l}28 \\
32 \\
29 \\
30 \\
28 \\
31 \\
31 \\
31 \\
33 \\
30 \\
46 \\
42 \\
32 \\
30 \\
32 \\
47 \\
32 \\
32 \\
34 \\
48 \\
30 \\
32 \\
32 \\
40 \\
52 \\
47 \\
38 \\
34 \\
32 \\
31 \\
28 \\
30 \\
27 \\
28 \\
29 \\
31 \\
30 \\
30 \\
32 \\
31 \\
30\end{array}$ & $\begin{array}{l}28 \\
41 \\
28 \\
34 \\
27 \\
38 \\
36 \\
39 \\
43 \\
48 \\
45 \\
44 \\
33 \\
33 \\
25 \\
48 \\
35 \\
32 \\
39 \\
52 \\
50 \\
41 \\
39 \\
33 \\
45 \\
61 \\
50.5 \\
48 \\
52.5 \\
42.0 \\
31 \\
28 \\
31 \\
27 \\
28 \\
28 \\
33 \\
37 \\
26 \\
33 \\
36 \\
42\end{array}$ & $\begin{array}{l}44.5 \\
70 \\
45 \\
62 \\
43 \\
73 \\
74.5 \\
71 \\
59.6 \\
60.5 \\
55.6 \\
56.5 \\
71.2 \\
72.8 \\
52.8 \\
57.0 \\
58.6 \\
45.3 \\
68.0 \\
74.5 \\
54 \\
65.3 \\
46.3 \\
69.5 \\
52.0 \\
83.0 \\
48.0 \\
61.0 \\
73.0 \\
76.0 \\
67.0 \\
62.0 \\
72.0 \\
63.5 \\
63.0 \\
61.4 \\
74.5 \\
76.0 \\
63.0 \\
54.7 \\
75.5 \\
63.3\end{array}$ & $\begin{array}{l}37.4 \\
66.2 \\
38.5 \\
56.8 \\
34.4 \\
69.5 \\
73.9 \\
68.0 \\
52.2 \\
53.0 \\
47.1 \\
49.5 \\
67.5 \\
68.1 \\
47.6 \\
52.0 \\
53.4 \\
42.2 \\
56.0 \\
71.0 \\
50 \\
61.4 \\
43.5 \\
69.0 \\
57.0 \\
93.5 \\
47.0 \\
54.0 \\
70.0 \\
55.4 \\
40.0 \\
37.0 \\
46.0 \\
32.5 \\
35.5 \\
35.4 \\
61.5 \\
63 \\
50 \\
37.4 \\
67.1 \\
66.0\end{array}$ & 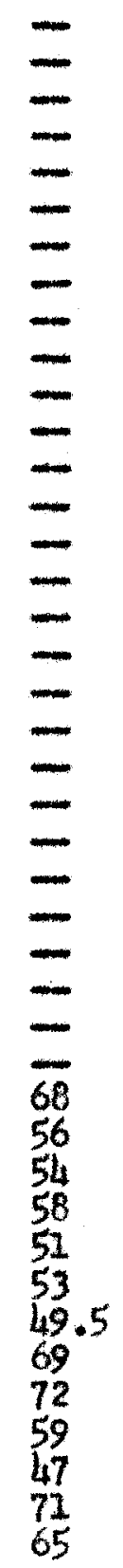 & $\begin{array}{l}36 \\
46.4 \\
36 \\
44 \\
38 \\
48 \\
50 \\
46 \\
46 \\
49 \\
53 \\
47 \\
43 \\
46 \\
41 \\
52 \\
40 \\
48 \\
53 \\
52.5 \\
42 \\
42 \\
49 \\
45.5 \\
63 \\
49.5 \\
50 \\
54 \\
49.5 \\
47.0 \\
43.0 \\
49.0 \\
45.0 \\
46.5 \\
42.6 \\
49.0 \\
51.5 \\
44.8 \\
46.0 \\
48.8 \\
44.2\end{array}$ \\
\hline
\end{tabular}


TABLE 4 (CONTINUED)

Average Tewperature ${ }^{\circ} \mathrm{y}$

\begin{tabular}{|c|c|c|c|c|c|c|}
\hline $\begin{array}{c}\text { Teat } \\
\text { No. }\end{array}$ & $\begin{array}{c}\text { Outside } \\
\text { Ground } \\
t_{\mathrm{g}}\end{array}$ & $\begin{array}{c}\text { Outside } \\
t_{a}\end{array}$ & $\begin{array}{c}\text { Inside } \\
\text { Alr } \\
t_{1}\end{array}$ & $\begin{array}{c}\text { Tent } \\
\text { Tabrte } \\
t_{\mathrm{D}}\end{array}$ & $\begin{array}{c}\text { Ifrer } \\
t_{L}\end{array}$ & $\begin{array}{l}\text { Ground } \\
\text { Cloth } \\
\text { (Floor) } \\
t_{f}\end{array}$ \\
\hline $\begin{array}{l}43 \\
44 \\
45 \\
46 \\
47 \\
48 \\
49 \\
50 \\
51 \\
52 \\
53 \\
54 \\
55 \\
56 \\
57 \\
58 \\
59 \\
60 \\
61 \\
62 \\
63 \\
64 \\
65 \\
66 \\
67 \\
68 \\
69 \\
70 \\
71 \\
72 \\
73 \\
74 \\
75 \\
76 \\
77\end{array}$ & $\begin{array}{l}32 \\
31 \\
32 \\
33 \\
32 \\
33 \\
32 \\
31 \\
28 \\
30 \\
30 \\
29 \\
27 \\
28 \\
31 \\
29 \\
38 \\
31 \\
42 \\
32 \\
32 \\
34 \\
32 \\
32 \\
33 \\
31 \\
31 \\
32 \\
47 \\
47 \\
46 \\
48 \\
50 \\
47 \\
48\end{array}$ & $\begin{array}{l}33 \\
39 \\
33 \\
42 \\
40 \\
40 \\
47 \\
31 \\
28 \\
27 \\
42 \\
31 \\
27 \\
28 \\
39 \\
28 \\
48 \\
33 \\
44 \\
40 \\
32 \\
52 \\
33.5 \\
39 \\
42 \\
38 \\
36 \\
34 \\
50 \\
48 \\
45 \\
50\end{array}$ & $\begin{array}{l}74.0 \\
79.5 \\
74.5 \\
62.0 \\
74.0 \\
55.5 \\
78.5 \\
66.5 \\
63.0 \\
66.0 \\
68.7 \\
84.5 \\
81.0 \\
82.0 \\
88.5 \\
76.0 \\
86.0 \\
80.0 \\
76 \\
79 \\
63 \\
83 \\
81 \\
61.5 \\
62.5 \\
74.0 \\
74.0 \\
74.0 \\
61.4 \\
73.0 \\
73.0 \\
78.5 \\
72.0 \\
72.0 \\
64.0\end{array}$ & $\begin{array}{l}66.7 \\
61.0 \\
60.5 \\
47.0 \\
73.0 \\
48.7 \\
58.9 \\
40.3 \\
34.5 \\
54.0 \\
65.0 \\
39.6 \\
28.5 \\
28.7 \\
66.0 \\
35.4 \\
50.0 \\
63.0 \\
48.5 \\
68.0 \\
36.0 \\
71.0 \\
70.0 \\
42.0 \\
44.0 \\
64.0 \\
67.0 \\
67.0 \\
54.0 \\
52.5 \\
48.0 \\
48.5 \\
53.0 \\
52.0 \\
56.2\end{array}$ & $\begin{array}{l}70 \\
76 \\
69 \\
58 \\
76.5 \\
54 \\
71 \\
59 \\
55 \\
61 \\
70 \\
82 \\
80 \\
80 \\
90 \\
76 \\
87 \\
77 \\
75 \\
79 \\
59 \\
82 \\
78 \\
59 \\
59 \\
72 \\
73 \\
74 \\
66 \\
67 \\
76 \\
66 \\
66 \\
-\end{array}$ & $\begin{array}{l}50.0 \\
52.7 \\
47.7 \\
47.5 \\
49.5 \\
43.2 \\
50.0 \\
45.5 \\
43.5 \\
45.8 \\
46.2 \\
56.0 \\
54.5 \\
55.5 \\
55.5 \\
48.3 \\
60.2 \\
51.0 \\
54.5 \\
52.5 \\
46.0 \\
57.8 \\
52.7 \\
46.1 \\
48.1 \\
51.3 \\
49.3 \\
50.8 \\
50 \\
55 \\
60 \\
56 \\
62 \\
61 \\
58\end{array}$ \\
\hline
\end{tabular}


TABLE 5 TEAPERATURE DIFFEREACES

\begin{tabular}{|c|c|c|c|c|c|c|c|}
\hline Rost & $\begin{array}{l}\text { Inside } \\
\text { Alr } \\
\text { Iimus } \\
\text { Inside } \\
\text { Surface } \\
\left(t_{1}-t_{\Delta} \text { or } t_{D}\right) \\
\Delta t_{18}\end{array}$ & $\begin{array}{l}\text { Iner } \\
\text { Minus } \\
\text { Tent } \\
\text { Fabric } \\
\left(t_{L^{-t}}\right) \\
\left.\Delta E_{D D}\right)\end{array}$ & $\begin{array}{c}\text { Tent } \\
\text { rabrio } \\
\text { udruas } \\
\text { outside } \\
\text { Alr } \\
\left(t_{\mathrm{D}}^{-t_{\mathrm{a}}}\right) \\
\Delta t_{\mathrm{Da}}\end{array}$ & $\begin{array}{l}\text { Inside } \\
\text { Alr } \\
\text { linus } \\
\text { Oatside } \\
\text { Alr } \\
\left(t_{1}-t_{a}\right) \\
\Delta t_{1 a}\end{array}$ & 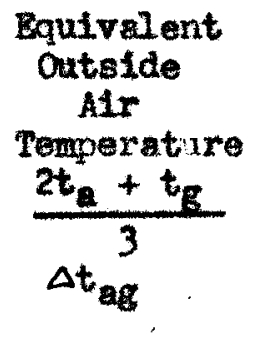 & 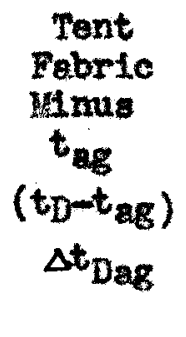 & $\begin{array}{l}\text { Inside } \\
\text { Air } \\
\text { Minus } \\
t_{\text {ag }} \\
\left(t_{1}-t_{\text {gg }}\right) \\
\Delta t_{\text {Iag }}\end{array}$ \\
\hline $\begin{array}{l}1 \\
2 \\
3 \\
4 \\
5 \\
6 \\
7 \\
8 \\
9 \\
10 \\
11 \\
12 \\
13 \\
14 \\
15 \\
16 \\
17 \\
18 \\
19 \\
20 \\
21 \\
22 \\
23 \\
24 \\
25 \\
26 \\
27 \\
28 \\
29 \\
30 \\
31 \\
32 \\
33 \\
34 \\
35 \\
36 \\
37 \\
38 \\
39 \\
40\end{array}$ & $\begin{array}{r}7.1 \\
3.8 \\
6.5 \\
5.2 \\
8.6 \\
3.5 \\
0.6 \\
3.0 \\
7.4 \\
7.5 \\
8.5 \\
7.0 \\
3.7 \\
4.7 \\
5.2 \\
5.0 \\
3.1 \\
12.0 \\
3.5 \\
4.0 \\
3.9 \\
2.8 \\
0.5 \\
-5.0 \\
-10.5 \\
1.0 \\
7.0 \\
3.0 \\
8.0 \\
11.0 \\
8.0 \\
11.0 \\
12.5 \\
10.0 \\
11.9 \\
5.5 \\
4.0 \\
4.0 \\
7.7\end{array}$ & $\begin{array}{l}= \\
= \\
= \\
= \\
= \\
= \\
= \\
= \\
= \\
= \\
= \\
= \\
= \\
= \\
= \\
= \\
12.6 \\
10.0 \\
17.0 \\
18.0 \\
18.5 \\
90.0\end{array}$ & $\begin{array}{r}9.4 \\
25.2 \\
10.5 \\
22.8 \\
7.4 \\
31.5 \\
37.9 \\
29.0 \\
9.2 \\
5.0 \\
2.1 \\
5.5 \\
34.5 \\
35.1 \\
22.6 \\
4.0 \\
10.2 \\
17.0 \\
29.0 \\
0 \\
20.4 \\
4.5 \\
36.0 \\
12.0 \\
32.5 \\
-3.5 \\
6.0 \\
17.5 \\
23.4 \\
9.0 \\
9.0 \\
15.0 \\
5.5 \\
7.5 \\
7.4 \\
28.5 \\
26.0 \\
24.0 \\
4.44\end{array}$ & $\begin{array}{r}16.5 \\
29.0 \\
17.0 \\
28.0 \\
16.0 \\
35.0 \\
38.5 \\
32.0 \\
16.0 \\
12.5 \\
10.6 \\
12.5 \\
38.2 \\
39.8 \\
27.8 \\
9.0 \\
13.0 \\
29.0 \\
22.5 \\
4.0 \\
24.3 \\
7.3 \\
36.5 \\
7.0 \\
22.0 \\
-2.5 \\
13.0 \\
20.5 \\
34.0 \\
36.0 \\
34.0 \\
41.0 \\
36.5 \\
35.0 \\
33.44 \\
41.5 \\
39.0 \\
37.0 \\
21.7\end{array}$ & 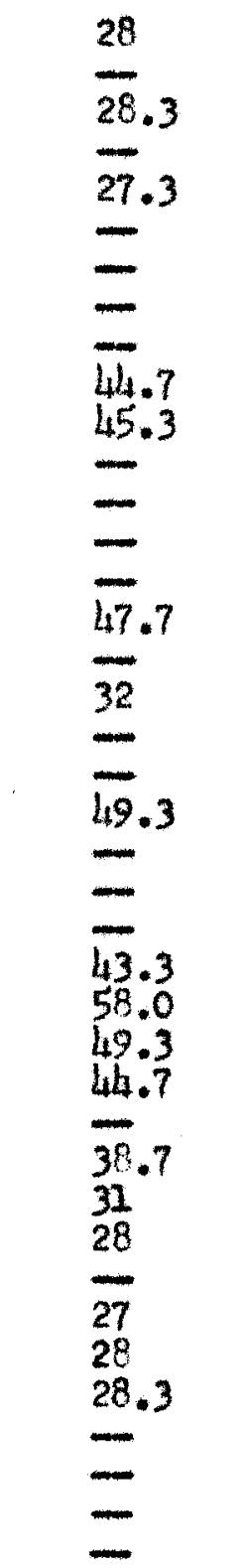 & 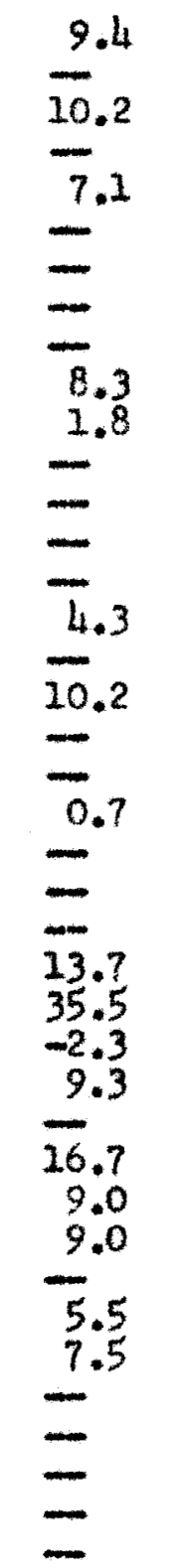 & 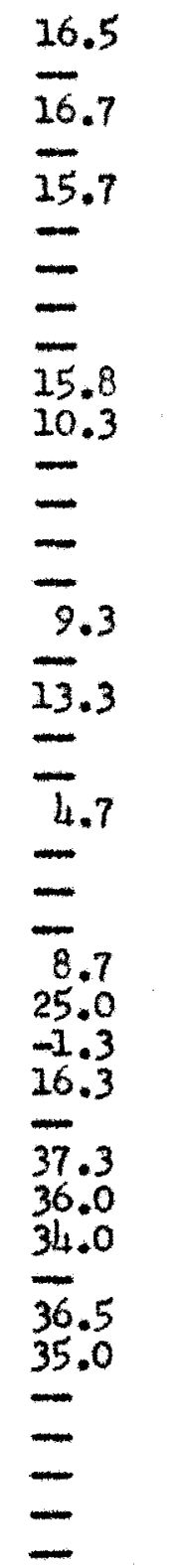 \\
\hline
\end{tabular}


TABLE 5 (CONTINUED)

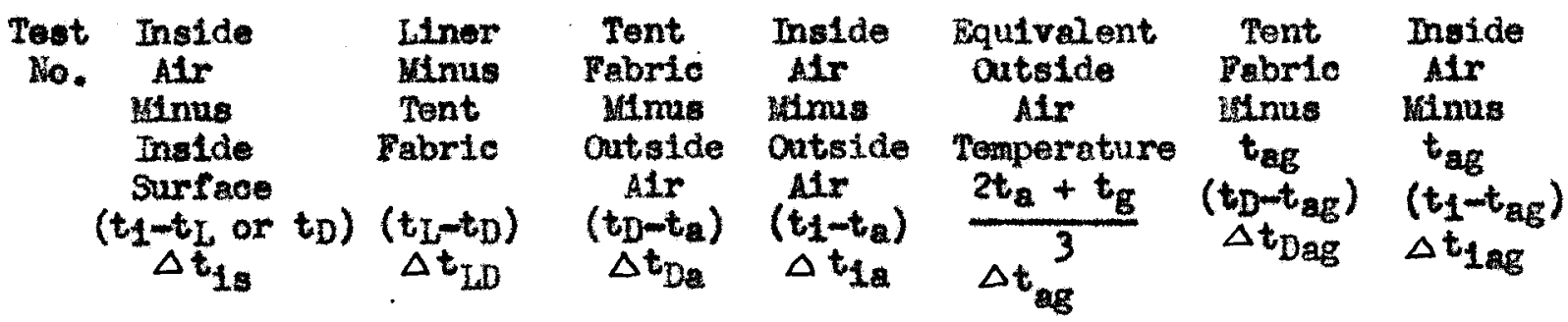

\begin{tabular}{|c|c|c|c|c|c|c|c|}
\hline $\begin{array}{l}41 \\
42 \\
43 \\
44 \\
45 \\
46 \\
47 \\
48 \\
49 \\
50 \\
51 \\
52 \\
53 \\
54 \\
55 \\
56 \\
57 \\
58 \\
59 \\
60 \\
61 \\
62 \\
63 \\
64 \\
65 \\
60 \\
57 \\
68 \\
69 \\
70 \\
71 \\
72 \\
73 \\
74 \\
75 \\
76 \\
77\end{array}$ & $\begin{array}{r}4.5 \\
-1.7 \\
4.0 \\
3.5 \\
5.5 \\
4.0 \\
-2.5 \\
1.5 \\
7.5 \\
7.5 \\
8.0 \\
5.0 \\
-1.3 \\
2.5 \\
1.0 \\
2.0 \\
-1.5 \\
0 \\
-1.0 \\
3.0 \\
1.0 \\
0 \\
4.0 \\
1.0 \\
3.0 \\
2.5 \\
3.5 \\
2.0 \\
1.0 \\
0 \\
7.4 \\
7.0 \\
6.0 \\
2.5 \\
6.0 \\
6.0 \\
7.8\end{array}$ & $\begin{array}{r}3.9 \\
-1.0 \\
3.3 \\
15.0 \\
8.5 \\
11.0 \\
3.5 \\
5.3 \\
12.1 \\
18.7 \\
20.5 \\
7.0 \\
5.0 \\
43.4 \\
51.5 \\
51.3 \\
21.0 \\
40.6 \\
37.0 \\
14.0 \\
26.5 \\
11.0 \\
23.0 \\
11.0 \\
8.0 \\
17.0 \\
15.0 \\
8.0 \\
6.0 \\
7.0 \\
13.5 \\
19.0 \\
27.5 \\
13.0 \\
14.0 \\
-0\end{array}$ & $\begin{array}{r}31.1 \\
24.0 \\
33.7 \\
22.0 \\
27.5 \\
5.0 \\
33.0 \\
8.7 \\
17.9 \\
9.3 \\
6.5 \\
27.0 \\
23.0 \\
7.6 \\
1.5 \\
0.7 \\
28.0 \\
7.4 \\
2.0 \\
30.0 \\
4.5 \\
28.0 \\
4.0 \\
19.0 \\
36.5 \\
3.0 \\
2.0 \\
26.0 \\
31.0 \\
33.0 \\
4.0 \\
4.5 \\
3.0 \\
-1.5 \\
3.0 \\
6.0 \\
8.2\end{array}$ & $\begin{array}{l}39.5 \\
21.3 \\
41.0 \\
40.5 \\
41.5 \\
20.0 \\
34.0 \\
15.5 \\
37.5 \\
35.5 \\
35.0 \\
39.0 \\
26.7 \\
53.5 \\
54.0 \\
54.0 \\
50.5 \\
48.0 \\
38.0 \\
47.0 \\
32 \\
39 \\
31 \\
31 \\
47.5 \\
22.5 \\
20.5 \\
36.0 \\
38 \\
40 \\
11.4 \\
25.0 \\
28.0 \\
28.5 \\
22.0 \\
26.0 \\
16.0\end{array}$ & 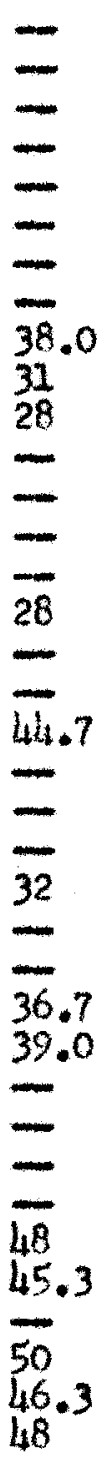 & 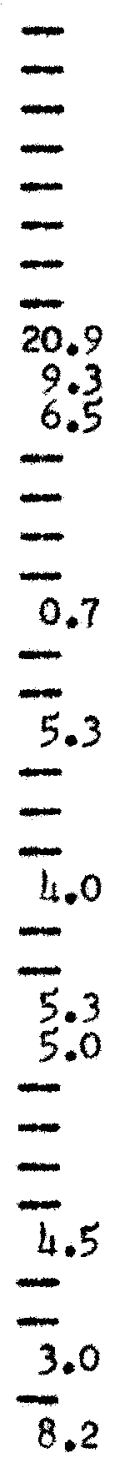 & 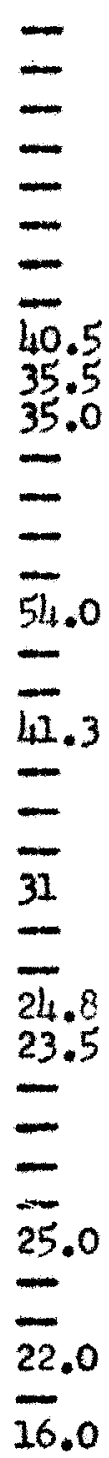 \\
\hline
\end{tabular}


TABLE 6 OVERALI AND TNUTV DUAL COEFFICTENTS OF HEAT TRANSFER

\begin{tabular}{|c|c|c|c|c|c|c|}
\hline \multirow[b]{2}{*}{$\begin{array}{l}\text { Test } \\
\text { llo. }\end{array}$} & \multicolumn{4}{|c|}{ Individual Coefficlents } & \multicolumn{2}{|c|}{ overell coefficient } \\
\hline & $\begin{array}{c}\text { Inside } \\
\text { Alr to } \\
\text { Inside } \\
\text { Surface } \\
\text { his }\end{array}$ & $\begin{array}{l}\text { Liner } \\
\text { To } \\
\text { Tent } \\
\text { Fabric } \\
\text { hLD }\end{array}$ & $\begin{array}{l}\text { Tent } \\
\text { Fabrie } \\
\text { To } \\
\text { Oatside } \\
\text { Alr } \\
\mathrm{h}_{\mathrm{Da}}\end{array}$ & $\begin{array}{l}\text { Tent } \\
\text { Fabrio } \\
\text { To } \\
t_{\text {ag }} \\
h_{\text {Das }}\end{array}$ & $\begin{array}{l}\text { Inside } \\
\text { Alrto } \\
\text { Outside } \\
\text { Alr } \\
\text { Ua }\end{array}$ & $\begin{array}{l}\text { Inside } \\
\text { Alx } \\
\text { To } \\
t_{a g} \\
t_{\text {Lag }}\end{array}$ \\
\hline $\begin{array}{l}1 \\
2 \\
3 \\
4 \\
5 \\
6 \\
7 \\
8 \\
9 \\
10 \\
11 \\
12 \\
13 \\
14 \\
15 \\
16 \\
17 \\
18 \\
19 \\
20 \\
21 \\
22 \\
23 \\
24 \\
25 \\
26 \\
27 \\
28 \\
29 \\
30 \\
31 \\
32 \\
33 \\
34 \\
35 \\
36 \\
37 \\
38 \\
39 \\
40\end{array}$ & $\begin{array}{c}2.94 \\
5.50 \\
2.92 \\
3.94 \\
2.38 \\
5.30 \\
32.7 \\
6.79 \\
2.50 \\
2.80 \\
1.57 \\
1.91 \\
3.92 \\
2.81 \\
2.60 \\
2.00 \\
3.12 \\
0.83 \\
3.08 \\
1.67 \\
1.71 \\
2.38 \\
13.3 \\
-1 \\
- \\
= \\
3.00 \\
3.60 \\
2.60 \\
1.89 \\
2.60 \\
1.46 \\
1.64 \\
2.04 \\
1.59 \\
2.41 \\
3.34 \\
3.37 \\
1.34\end{array}$ & 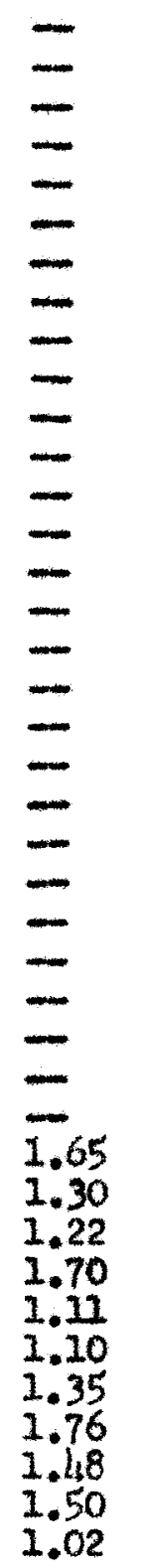 & $\begin{array}{l}2.22 \\
0.83 \\
1.81 \\
0.90 \\
2.76 \\
0.59 \\
0.52 \\
0.70 \\
2.01 \\
4.20 \\
6.36 \\
2.32 \\
0.42 \\
0.38 \\
0.60 \\
2.50 \\
-0.96 \\
0.79 \\
0.57 \\
00 \\
0.33 \\
1.48 \\
0.19 \\
- \\
- \\
= \\
3.50 \\
0.62 \\
1.55 \\
2.37 \\
2.32 \\
1.36 \\
3.73 \\
2.72 \\
2.57 \\
0.46 \\
0.51 \\
0.56 \\
2.22\end{array}$ & 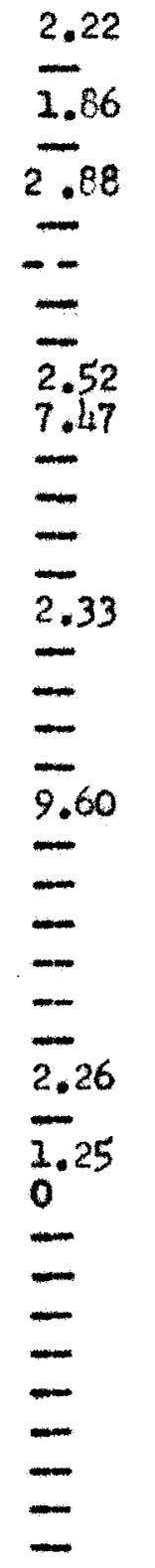 & $\begin{array}{l}1.26 \\
0.72 \\
1.12 \\
0.73 \\
1.28 \\
0.53 \\
0.51 \\
0.64 \\
1.11 \\
1.67 \\
1.26 \\
1.07 \\
0.38 \\
0.33 \\
0.49 \\
1.11 \\
-0.73 \\
0.35 \\
0.48 \\
1.67 \\
0.27 \\
0.89 \\
0.18 \\
-0 \\
- \\
- \\
1.61 \\
0.52 \\
0.61 \\
0.58 \\
0.61 \\
0.50 \\
0.56 \\
0.58 \\
0.57 \\
0.32 \\
0.34 \\
0.36 \\
0.45\end{array}$ & 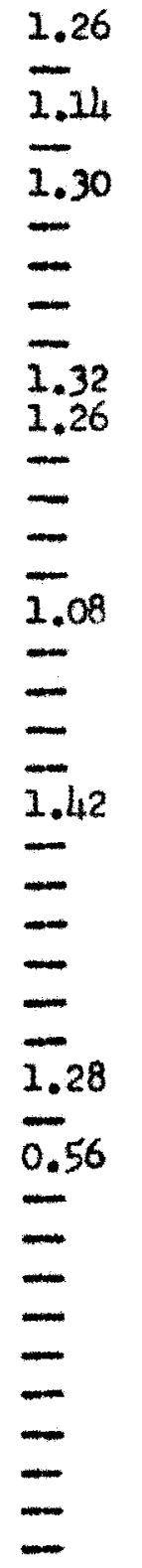 \\
\hline
\end{tabular}


TABLE 6 (CONTANUED)

Individual Coefficlents

\begin{tabular}{|c|c|c|c|c|c|}
\hline \multicolumn{4}{|c|}{ Individual Coefficlents } & \multicolumn{2}{|c|}{ Overall Coelflelent } \\
\hline $\begin{array}{l}\text { Instde } \\
\text { Atr to } \\
\text { Inside } \\
\text { Surfece } \\
\text { h1s }\end{array}$ & $\begin{array}{l}\text { Iner } \\
\text { To } \\
\text { Tent } \\
\text { Pebric } \\
\text { hLD }\end{array}$ & $\begin{array}{l}\text { Tont } \\
\text { Fabric } \\
\text { To } \\
\text { outside } \\
\text { Air } \\
\text { hn }\end{array}$ & $\begin{array}{l}\text { Tent } \\
\text { Pabrle } \\
\text { To } \\
t_{\text {ag }} \\
\text { hDag }_{\text {Dag }}\end{array}$ & $\begin{array}{l}\text { Inside } \\
\text { Alr to } \\
\text { outgide } \\
\text { Alr } \\
\mathrm{U}_{1 a}\end{array}$ & $\begin{array}{c}\text { Instde } \\
\text { Alr } \\
\text { To } \\
t_{\text {ag }} \\
\text { U }_{\text {lag }}\end{array}$ \\
\hline
\end{tabular}

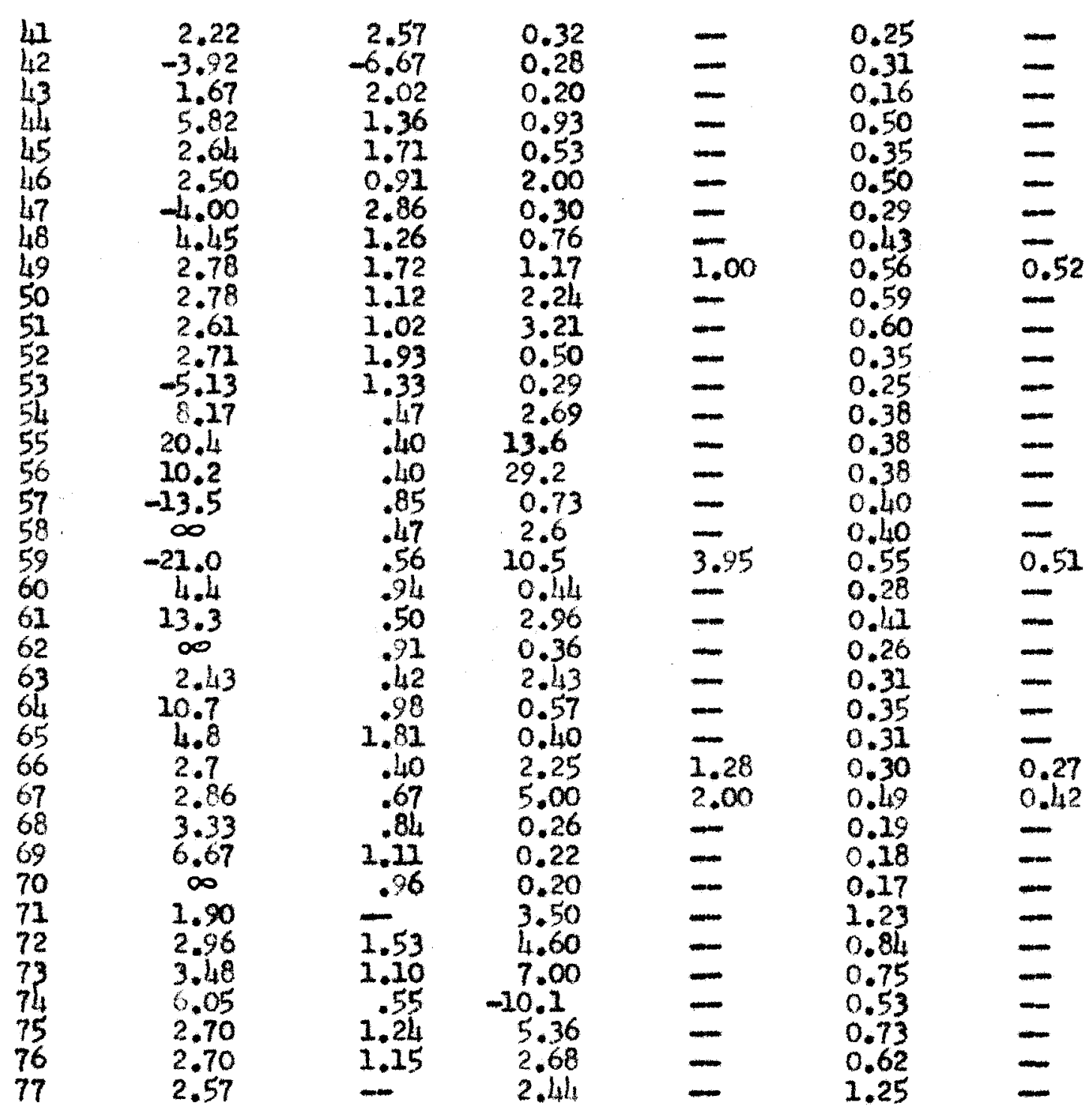


TAELE 6 (CONTINUED)

Indiridial Coefficients

overall coefficlent

\begin{tabular}{|c|c|c|c|c|c|c|}
\hline $\begin{array}{l}\text { Type } \\
\text { IIner }\end{array}$ & $\begin{array}{l}\text { Inside } \\
\text { Alr to } \\
\text { Instde } \\
\text { Surface } \\
\text { his }\end{array}$ & $\begin{array}{l}\text { Liner } \\
\text { To } \\
\text { Tent } \\
\text { Febrie } \\
\text { hLD }\end{array}$ & $\begin{array}{l}\text { Tent } \\
\text { Fabric } \\
\text { To } \\
\text { outside } \\
\text { Air } \\
\text { bDa }\end{array}$ & $\begin{array}{l}\text { Tent } \\
\text { Pabric } \\
\text { To } \\
\text { tag }_{\text {ag }} \\
\text { bDag }\end{array}$ & $\begin{array}{l}\text { Inside } \\
\text { Alr to } \\
\text { Oatside } \\
\text { Air } \\
\text { Uia }\end{array}$ & $\begin{array}{c}\text { Inside } \\
\text { Alr To } \\
\text { tog } \\
\text { tag }\end{array}$ \\
\hline
\end{tabular}

\section{LARGE WALL TLWT}

Average Values (Mght and Overcest Runs)

\begin{tabular}{|c|c|c|c|c|c|c|}
\hline Do Inner & 2.5 & - & 2.6 & 2.5 & 1.27 & 1.26 \\
\hline 4 oz. Cotton & 2.5 & 1.3 & 2.5 & 2.5 & .58 & .58 \\
\hline 8 oz. Cotton & 2.5 & 2.3 & 2.5 & 2.5 & .58 & .58 \\
\hline $\begin{array}{l}\text { 1/2 Inch } \\
\text { Mberglas }\end{array}$ & - & 0.5 & - & - & .40 & .39 \\
\hline
\end{tabular}


TABLE 7 COMPORT IMDEX

$\begin{array}{ccll}\text { Test } & \text { Inside } & \text { Average } & \text { Comfort } \\ \text { No. } & \text { Air } & \text { Inside } & \text { Index } \\ & t_{1} & \begin{array}{l}\text { Surface } \\ \text { Temperature }\end{array} & t_{1}+t_{s} \\ & & t_{s} & \end{array}$

$\begin{array}{llll}1 & 44.5 & 37.1 & 81.6 \\ 2 & 70 & 60.7 & 130.7 \\ 3 & 45 & 37.8 & 82.8 \\ 4 & 62 & 53.4 & 115.4 \\ 5 & 43 & 35.5 & 78.5 \\ 6 & 73 & 63.7 & 136.7 \\ 7 & 74.5 & 67.5 & 11.0 \\ 8 & 71.0 & 62.1 & 133.1 \\ 9 & 59.6 & 50.6 & 110.2 \\ 10 & 60.5 & 51.9 & 112.4 \\ 11 & 55.6 & 48.8 & 104.4 \\ 12 & 56.5 & 48.9 & 105.4 \\ 13 & 71.2 & 61.0 & 132.2 \\ 14 & 72.8 & 62.1 & 134.9 \\ 15 & 52.8 & 45.9 & 98.7 \\ 16 & 57.0 & 53.3 & 110.3 \\ 17 & 58.6 & 51.3 & 13.9 \\ 18 & 45.3 & 41.6 & 86.9 \\ 19 & 68.0 & 53.9 & 121.9 \\ 20 & 74.5 & 66.1 & 140.6 \\ 21 & 54.0 & 50.7 & 104.7 \\ 22 & 65.3 & 56.1 & 121.4 \\ 23 & 46.3 & 43.2 & 89.5 \\ 24 & 69.5 & 63.6 & 133.1 \\ 25 & 52.0 & 53.9 & 105.9 \\ 26 & 83.0 & 85.3 & 168.3 \\ 27 & 48.0 & 47.6 & 95.6 \\ 26 & 61.0 & 53.0 & 114.0 \\ 29 & 73.0 & 65.7 & 138.7 \\ 30 & 76.0 & 63.1 & 139.1 \\ 31 & 67.0 & 53.7 & 120.7 \\ 32 & 62.0 & 51.2 & 113.2 \\ 33 & 72.0 & 55.6 & 127.6 \\ 34 & 63.5 & 49.5 & 113.0 \\ 35 & 63.0 & 51.2 & 114.2 \\ 36 & 61.4 & 47.5 & 108.9 \\ 37 & 74.5 & 63.7 & 138.2 \\ 38 & 76.0 & 66.6 & 142.6 \\ 39 & 63.0 & 55.4 & 118.4 \\ 40 & 54.7 & 46.8 & 101.5 \\ 41 & 76.5 & 65.3 & 140.8 \\ 42 & 63.3 & 59.5 & 122.8\end{array}$


TABLE 7 (CONTINUED)

$\begin{array}{ccll}\text { Test } & \text { Ins1de } & \text { Average } & \text { Comfort } \\ \text { No. } & \text { AIr } & \text { Inside } & \text { Index } \\ & t_{1} & \begin{array}{c}\text { Surface } \\ \text { Terapersture } \\ t_{2}\end{array} & t_{i}+t_{s} \\ & & & \end{array}$

$\begin{array}{llll}43 & 74.0 & 64.9 & 138.9 \\ 44 & 79.5 & 69.5 & 149.0 \\ 45 & 74.5 & 63.0 & 137.5 \\ 46 & 62.0 & 54.9 & 116.9 \\ 47 & 74.0 & 68.7 & 142.7 \\ 48 & 55.5 & 50.8 & 106.3 \\ 49 & 78.5 & 65.6 & 144.1 \\ 50 & 66.5 & 55.6 & 122.1 \\ 51 & 63.0 & 52.1 & 115.1 \\ 52 & 66.0 & 57.0 & 123.0 \\ 53 & 68.7 & 64.0 & 132.7 \\ 54 & 84.5 & 75.5 & 160.0 \\ 55 & 81.0 & 73.6 & 154.6 \\ 56 & 82.0 & 73.9 & 155.9 \\ 57 & 88.5 & 81.4 & 169.9 \\ 58 & 76.0 & 69.0 & 145.0 \\ 59 & 86.0 & 80.4 & 186.4 \\ 60 & 80.0 & 70.5 & 150.5 \\ 61 & 76.0 & 69.9 & 145.9 \\ 62 & 79.0 & 72.5 & 151.5 \\ 63 & 63.0 & 55.0 & 118.8 \\ 64 & 83.0 & 76.0 & 159.0 \\ 65 & 81.0 & 71.8 & 152.8 \\ 66 & 61.5 & 55.7 & 117.4 \\ 67 & 62.5 & 56.3 & 118.8 \\ 68 & 74.0 & 66.9 & 140.9 \\ 69 & 74.0 & 67.1 & 141.1 \\ 70 & 74.0 & 67.9 & 141.9 \\ 71 & 61.4 & 53.0 & 114.4 \\ 72 & 73.0 & 62.0 & 135.0 \\ 73 & 73.0 & 64.0 & 137.0 \\ 74 & 78.5 & 69.0 & 147.5 \\ 75 & 72.0 & 64.5 & 136.5 \\ 76 & 72.0 & 64.3 & 136.3 \\ 77 & 64.0 & 56.6 & 120.6 \\ & & & \\ & & & \end{array}$


TABLE 8 FUEL CONSMPTION AND SAVINGS WITH LAROE WALL TENT

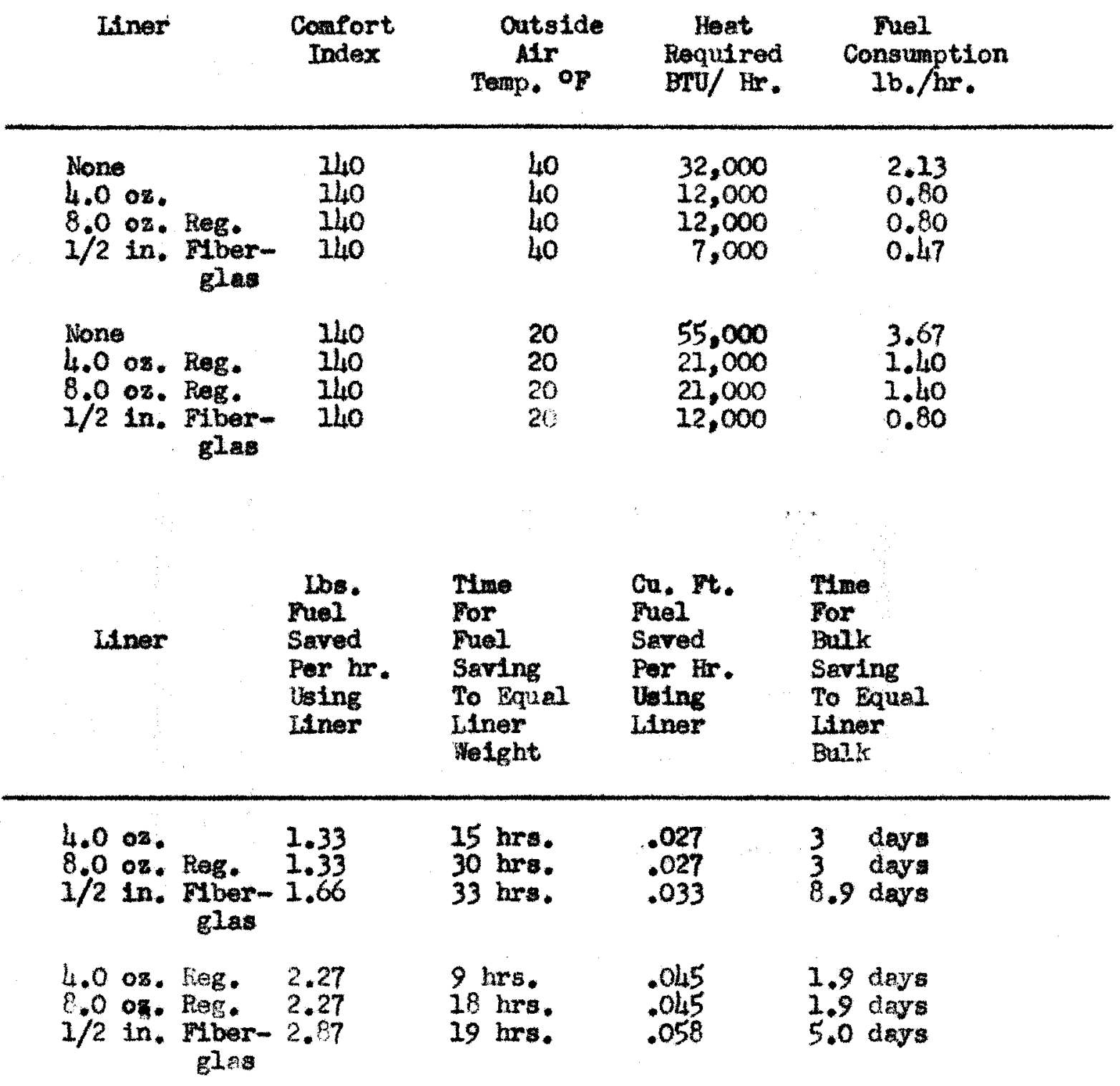


TABIE 9 COST, WTIOFT, BULK SUMAARY FOR ONE MONTH'S OPBRATION US WIG LAROE WALL TENT COMFORY $2170 \mathrm{EX}-140$

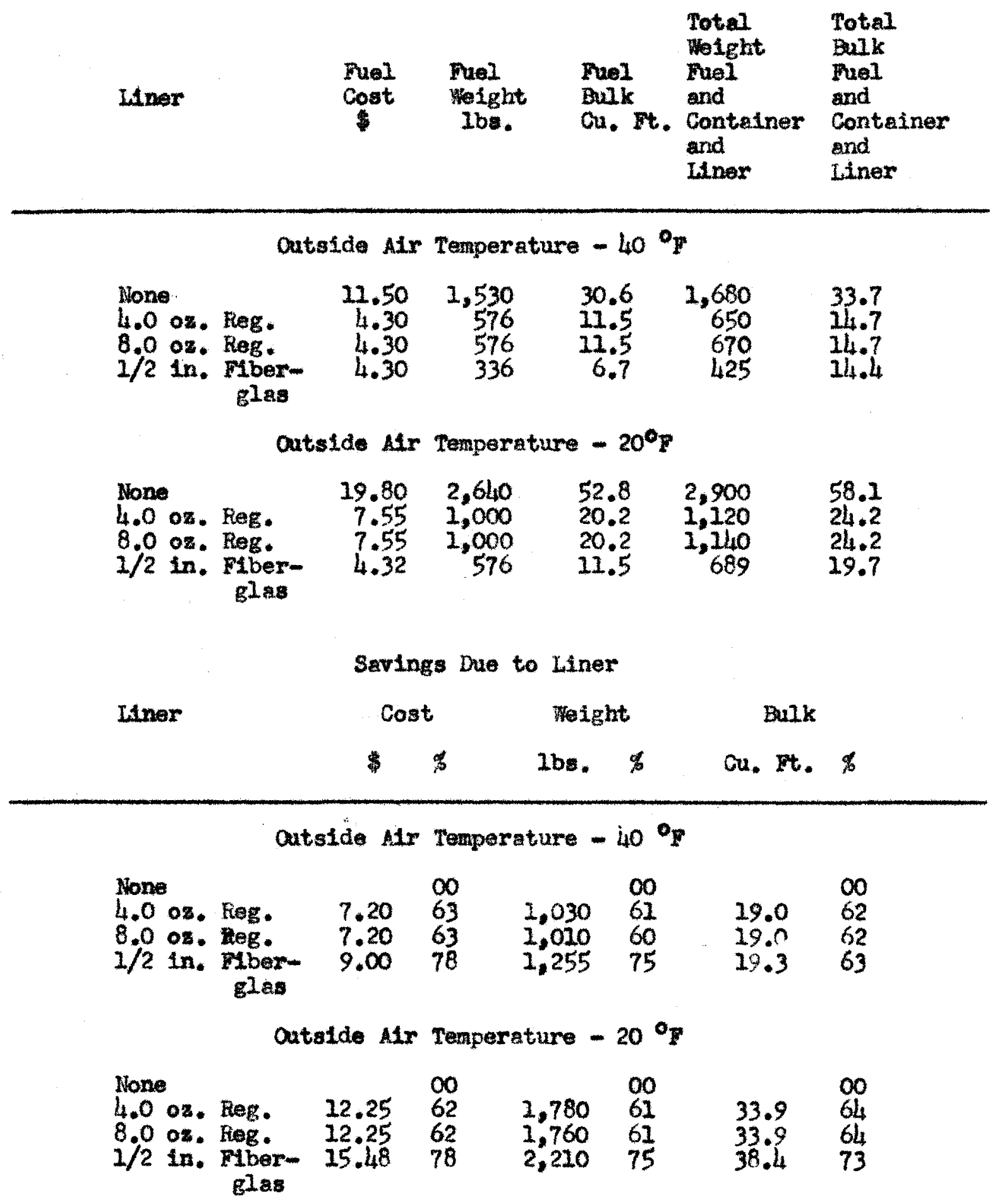


TABLE 10 TENT TELERRATURE DATA

DARCE HOODDD NLISS

$1011 \quad 2 \quad 344: 3010: 3011: 3012$
Temperature or.

Outalde Alr

$\begin{array}{lllllllll}71 & 72 & 75 & 76 & 76 & 75 & 80 & 83 & 86\end{array}$

outside Ground

$\begin{array}{lllllllll}80 & 89 & 81 & 78 & 76 & 75 & 88 & 88 & 96\end{array}$

Large Well Tent-No Fly-Closed

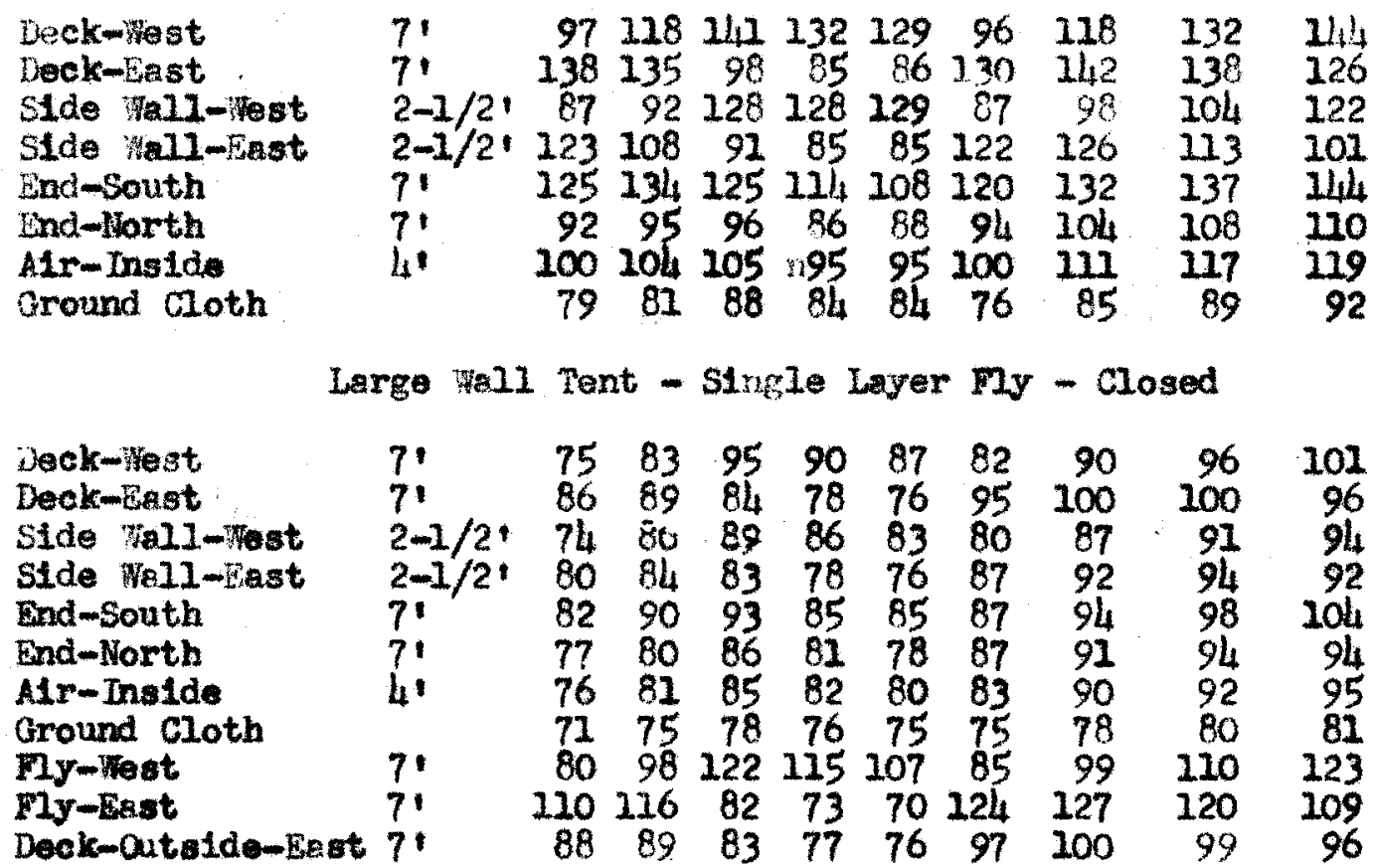


TABLE 10 (CONTINUED)

Time

$\begin{array}{lllllllll}10 & 11 & 12 & 1 & 2 & 3 & 1 & 2 & 3\end{array}$

Temperature ${ }^{\circ} \mathbf{F}$

\begin{tabular}{|c|c|c|c|c|c|c|c|c|c|c|}
\hline \multirow[t]{2}{*}{$\begin{array}{l}\text { Outside Air } \\
\text { Outside Ground }\end{array}$} & & $\begin{array}{l}67 \\
95\end{array}$ & $\begin{array}{r}69 \\
102\end{array}$ & $\frac{1}{3}$ & $\begin{array}{l}70 \\
97\end{array}$ & 71 & $\frac{0}{5}$ & 68 & $\begin{array}{l}68 \\
77\end{array}$ & $\begin{array}{l}67 \\
76\end{array}$ \\
\hline & Large wall & Tent & 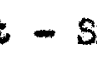 & & Laye: & - $\mathrm{Fy}$ & & sed & & \\
\hline \multirow[t]{2}{*}{$\begin{array}{l}\text { Fy-West } \\
\text { Fy-East } \\
\text { Deck-Nest } \\
\text { Deck-Eest } \\
\text { S1de Wall-West } \\
\text { SIde Wall-East } \\
\text { End-South } \\
\text { Find-North } \\
\text { Air-Inside } \\
\text { Ground Cloth } \\
\text { Deck-Outside-Ras }\end{array}$} & $\begin{array}{l}7 ! \\
7 ! \\
7 ! \\
7 ! \\
2-1 / 2 ! \\
2-1 / 2 ! \\
7 ! \\
7 ! \\
4 !\end{array}$ & $\begin{array}{l}80 \\
74 \\
84 \\
74 \\
77 \\
84 \\
78 \\
76 \\
68\end{array}$ & $\begin{array}{l}91 \\
80 \\
85 \\
77 \\
79 \\
86 \\
79 \\
79 \\
70 \\
83\end{array}$ & $\begin{array}{l}81 \\
81 \\
78 \\
78 \\
84 \\
84 \\
79 \\
71 \\
83\end{array}$ & $\begin{array}{l}80 \\
76 \\
78 \\
74 \\
84 \\
76 \\
76 \\
70 \\
78\end{array}$ & $\begin{array}{l}76 \\
80 \\
74 \\
77 \\
74 \\
83 \\
76 \\
77 \\
71\end{array}$ & 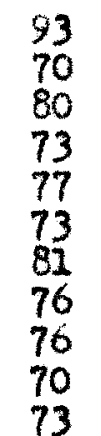 & $\begin{array}{l}96 \\
76 \\
78 \\
72 \\
77 \\
74 \\
85 \\
74 \\
76 \\
70 \\
74\end{array}$ & $\begin{array}{l}92 \\
68 \\
77 \\
70 \\
76 \\
71 \\
82 \\
74 \\
76 \\
70\end{array}$ & 56 \\
\hline & Large 芳ell & Tent & & & & & & & & \\
\hline 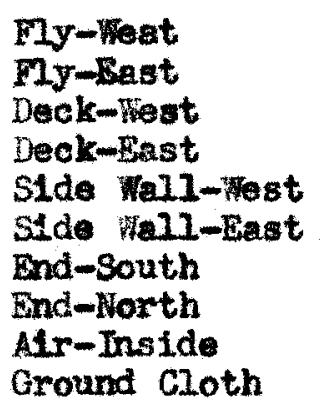 & $\begin{array}{l}7 ! \\
7 ! \\
7 ! \\
7 ! \\
2-1 / 2 ! \\
2-1 / 2 ! \\
? ! \\
7 ! \\
4 !\end{array}$ & $\begin{array}{l}86 \\
71 \\
75 \\
72 \\
75 \\
79 \\
71\end{array}$ & $\begin{array}{l}81 \\
9 \\
7 \\
8 \\
7 \\
75 \\
8 \\
7\end{array}$ & $\begin{array}{l}7 \\
7 \\
7 \\
7\end{array}$ & $\begin{array}{l}81 \\
73 \\
75 \\
73 \\
75 \\
75 \\
80 \\
75\end{array}$ & $\begin{array}{l}73 \\
79 \\
74 \\
75 \\
75 \\
80 \\
77\end{array}$ & $\begin{array}{l}? \\
7 \\
7 \\
7\end{array}$ & 78 & 7 & \\
\hline
\end{tabular}


TABLE 10 (CONT INUED)

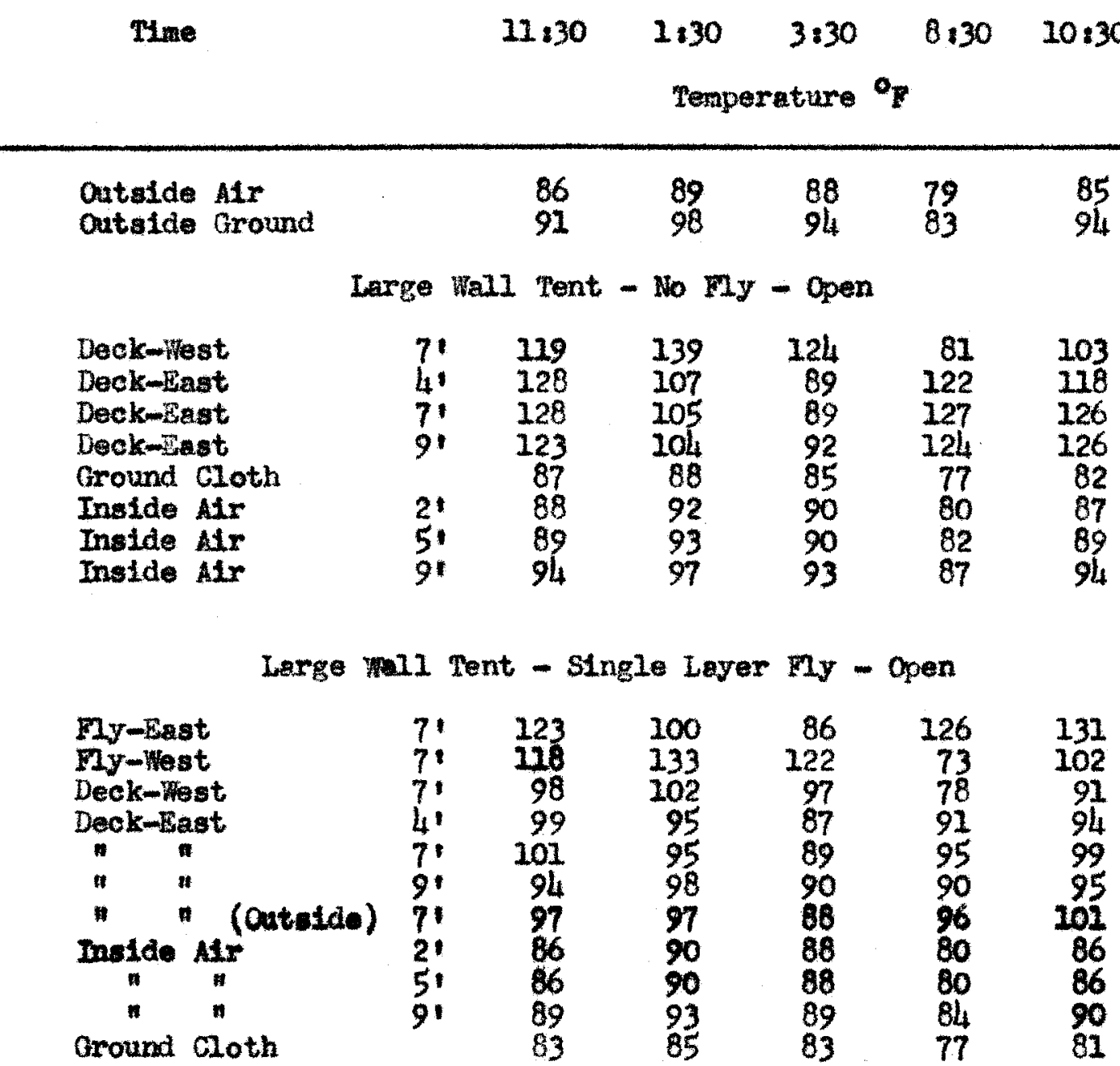


TABLE 10 (CONTIIUED)

$11: 30 \quad 12: 30 \quad 1830 \quad 2: 30 \quad 3: 30$

Tewperature ${ }^{\circ}$

\begin{tabular}{|c|c|c|c|c|c|c|}
\hline $\begin{array}{l}\text { Outside Air } \\
\text { Outside Ground }\end{array}$ & & $\begin{array}{l}65 \\
92\end{array}$ & $\begin{array}{l}75 \\
90\end{array}$ & $\begin{array}{l}76 \\
92\end{array}$ & $\begin{array}{r}76 \\
98\end{array}$ & $\begin{array}{l}76 \\
93\end{array}$ \\
\hline Large & al1 Tent & $-s$ & le La & Fy & - Open & \\
\hline 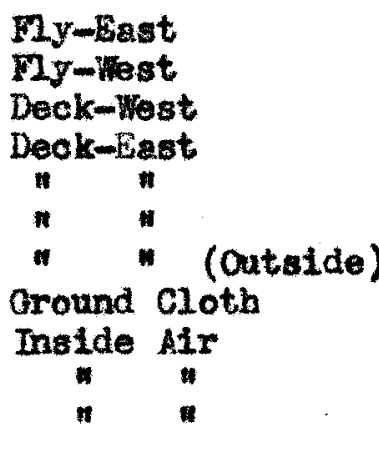 & $\begin{array}{l}7: \\
7 ! \\
7 ! \\
4: \\
7 ! \\
9 ! \\
7 ! \\
2 ! \\
5 ! \\
9 !\end{array}$ & $\begin{array}{l}\overline{89} \\
78 \\
80 \\
81 \\
77 \\
87 \\
70 \\
70 \\
71 \\
71\end{array}$ & $\begin{array}{r}102 \\
81 \\
81 \\
81 \\
79 \\
83 \\
72 \\
75 \\
75 \\
76\end{array}$ & $\begin{array}{r}103 \\
85 \\
80 \\
80 \\
82 \\
83 \\
75 \\
76 \\
76 \\
76\end{array}$ & $\begin{array}{r}117 \\
87 \\
79 \\
79 \\
78 \\
79 \\
74 \\
76 \\
76 \\
76\end{array}$ & $\begin{array}{l}\overline{96} \\
80 \\
74 \\
74 \\
74 \\
75 \\
71 \\
76 \\
76 \\
76\end{array}$ \\
\hline Large & 211 Tent & $-D$ & 101 & $2 y$ & - Open & \\
\hline $\begin{array}{l}\text { My-East } \\
\text { My-West } \\
\text { Deok-West } \\
\text { Deck-Eest } \\
n \\
\text { Ground aloth } \\
\text { Inalde Alr } \\
n=4 \\
n \quad n\end{array}$ & $\begin{array}{l}71 \\
71 \\
71 \\
41 \\
71 \\
91\end{array}$ & $\begin{array}{l}80 \\
77 \\
74 \\
74 \\
74 \\
76 \\
67 \\
71 \\
71 \\
70\end{array}$ & $\begin{array}{l}81 \\
83 \\
76 \\
76 \\
76 \\
75 \\
66 \\
74 \\
74 \\
74\end{array}$ & $\begin{array}{r}85 \\
105 \\
88 \\
82 \\
82 \\
82 \\
72 \\
77 \\
76 \\
76\end{array}$ & $\begin{array}{r}76 \\
100 \\
84 \\
78 \\
78 \\
79 \\
71 \\
76 \\
76 \\
76\end{array}$ & $\begin{array}{l}76 \\
92 \\
80 \\
76 \\
76 \\
76 \\
70 \\
76 \\
76 \\
75\end{array}$ \\
\hline
\end{tabular}


TABLE 11 AVERAGE TEMPETATURES - TENTS CLOSED

\begin{tabular}{|c|c|c|c|c|c|c|c|}
\hline \multirow{3}{*}{ The } & \multicolumn{7}{|c|}{ Average Temperature ${ }^{\circ}$} \\
\hline & \multirow[t]{2}{*}{$\begin{array}{l}\text { Outgide } \\
\text { Air }\end{array}$} & Inatide & $\begin{array}{c}\text { Inside } \\
\text { Tent } \\
\text { Surface } \\
\end{array}$ & $\begin{array}{c}\text { Instide } \\
\text { Fyy } \\
\text { Surface } \\
\end{array}$ & $\begin{array}{l}\text { Inside } \\
\text { AIr }\end{array}$ & $\begin{array}{l}\text { Inside } \\
\text { Tent } \\
\text { Surface } \\
\end{array}$ & $\begin{array}{c}\text { Inside } \\
\text { Ny } \\
\text { Surface } \\
\end{array}$ \\
\hline & & \multicolumn{3}{|c|}{ No $\mathrm{Fly}$} & \multicolumn{3}{|c|}{ Single Layer $\mathrm{ny}$} \\
\hline \multirow[t]{2}{*}{$\begin{array}{r}10: 00 \\
11: 00 \\
2: 00 \\
3: 00 \\
4: 00 \\
9: 30 \\
10: 30 \\
11: 30 \\
12: 30\end{array}$} & $\begin{array}{l}71 \\
72 \\
75 \\
76 \\
76 \\
75 \\
80 \\
83 \\
86\end{array}$ & $\begin{array}{r}100 \\
104 \\
105 \\
95 \\
95 \\
100 \\
111 \\
117 \\
119\end{array}$ & $\begin{array}{l}112 \\
217 \\
114 \\
105 \\
104 \\
109 \\
122 \\
125 \\
127\end{array}$ & $\begin{array}{l}= \\
\bar{I} \\
=\end{array}$ & $\begin{array}{l}76 \\
81 \\
85 \\
82 \\
80 \\
83 \\
90 \\
92 \\
95\end{array}$ & $\begin{array}{l}80 \\
85 \\
89 \\
84 \\
81 \\
86 \\
93 \\
96 \\
98\end{array}$ & $\begin{array}{r}95 \\
107 \\
102 \\
94 \\
89 \\
105 \\
113 \\
115 \\
116\end{array}$ \\
\hline & & \multicolumn{3}{|c|}{ Double Layer $\mathrm{Ky}$} & \multicolumn{3}{|c|}{ Single layer $\mathrm{my}$} \\
\hline $\begin{array}{l}10: 00 \\
11: 00 \\
12: 00 \\
1: 00 \\
2: 00 \\
3: 00 \\
1: 00 \\
2: 00 \\
3: 00\end{array}$ & $\begin{array}{l}67 \\
69 \\
71 \\
70 \\
71 \\
70 \\
68 \\
67 \\
67\end{array}$ & $\begin{array}{l}71 \\
75 \\
76 \\
72 \\
74 \\
74 \\
73 \\
74 \\
72\end{array}$ & $\begin{array}{l}74 \\
79 \\
79 \\
75 \\
77 \\
74 \\
75 \\
72 \\
74\end{array}$ & $\begin{array}{l}80 \\
89 \\
82 \\
77 \\
81 \\
75 \\
80 \\
80 \\
77\end{array}$ & $\begin{array}{l}76 \\
79 \\
79 \\
76 \\
77 \\
76 \\
76 \\
76 \\
75\end{array}$ & $\begin{array}{l}79 \\
82 \\
80 \\
78 \\
78 \\
77 \\
77 \\
75 \\
76\end{array}$ & $\begin{array}{l}86 \\
95 \\
95 \\
79 \\
86 \\
81 \\
86 \\
80 \\
80\end{array}$ \\
\hline
\end{tabular}




\section{TABIX 12 AVERAGS TEAPERATUKES - TENTS OPEN}

\begin{tabular}{|c|c|c|c|c|c|c|c|}
\hline \multirow[t]{2}{*}{ Time } & \multirow[t]{2}{*}{$\begin{array}{c}\text { Cutside } \\
\text { Alr }\end{array}$} & $\begin{array}{l}\text { Inside } \\
\text { A1r }\end{array}$ & $\begin{array}{l}\text { Inside } \\
\text { Tent } \\
\text { Surface }\end{array}$ & $\begin{array}{l}\text { Inside } \\
\text { Ny } \\
\text { Surface } \\
\end{array}$ & $\begin{array}{l}\text { Inside } \\
\text { Alr }\end{array}$ & $\begin{array}{c}\text { Inside } \\
\text { Tent } \\
\text { Surface }\end{array}$ & $\begin{array}{l}\text { Inside } \\
\text { Fyy } \\
\text { Surface } \\
\end{array}$ \\
\hline & & \multicolumn{3}{|c|}{ No $\mathrm{Fiy}$} & \multicolumn{3}{|c|}{ Single Leyer $\$ 1 \mathrm{~J}$} \\
\hline $11: 30$ & 86 & 89 & 123 & - & 86 & 98 & 120 \\
\hline $1: 30$ & 89 & 93 & 121 & - & 90 & 99 & 116 \\
\hline $3: 30$ & 88 & 90 & 105 & - & 88 & 93 & 204 \\
\hline 8.30 & 79 & 81 & 102 & - & 80 & 85 & 100 \\
\hline \multirow[t]{2}{*}{$10: 30$} & 85 & 88 & 1214 & - & 86 & 93 & 126 \\
\hline & & \multicolumn{3}{|c|}{ Double Layer $\mathrm{ny}$} & \multicolumn{3}{|c|}{ Single Layer $\mathrm{my}$} \\
\hline $12: 30$ & 74 & 74 & 77 & 82 & 75 & 81 & - \\
\hline $1: 30$ & 76 & 77 & 85 & 95 & 76 & 83 & - \\
\hline $2: 30$ & 76 & 76 & 81 & 88 & 76 & 83 & - \\
\hline $3: 30$ & 76 & 76 & 78 & 84 & 76 & 77 & - \\
\hline
\end{tabular}


TABUE 13 TGMPERATURE DIFFERENCES

Instde Air Mnus Outalde Mir Inside Tent Surface ilinug Inside Air

\begin{tabular}{|c|c|c|c|c|c|c|}
\hline Plme & $\begin{array}{l}\text { No } \\
\text { FIy }\end{array}$ & $\begin{array}{l}\text { Single } \\
\text { Layer } \\
\text { Fly }\end{array}$ & $\begin{array}{l}\text { Double } \\
\text { Layer } \\
\text { Fly }\end{array}$ & $\begin{array}{l}\text { No } \\
\text { My }\end{array}$ & $\begin{array}{l}\text { Single } \\
\text { Layer } \\
\text { My }\end{array}$ & $\begin{array}{l}\text { Double } \\
\text { Layer } \\
\text { Fyy }\end{array}$ \\
\hline
\end{tabular}

\begin{tabular}{|c|c|c|c|c|c|c|}
\hline \multirow[b]{2}{*}{$\begin{array}{r}10: 00 \\
11: 00 \\
2: 00 \\
3: 00 \\
4: 00 \\
9: 30 \\
10: 30 \\
11: 30 \\
12: 30 \\
10: 00 \\
11: 00 \\
12: 00 \\
1: 00 \\
2: 00 \\
3: 00 \\
1: 00 \\
2: 00 \\
3: 00\end{array}$} & \multicolumn{6}{|c|}{ Tents Closed } \\
\hline & $\begin{array}{l}29 \\
32 \\
30 \\
19 \\
19 \\
25 \\
31 \\
34 \\
33 \\
= \\
= \\
= \\
= \\
= \\
=\end{array}$ & $\begin{array}{r}5 \\
9 \\
10 \\
6 \\
4 \\
8 \\
10 \\
9 \\
9 \\
9 \\
10 \\
8 \\
6 \\
6 \\
6 \\
8 \\
8 \\
8\end{array}$ & $\begin{array}{l}= \\
= \\
= \\
= \\
= \\
5 \\
6 \\
5 \\
2 \\
3 \\
5 \\
6 \\
5\end{array}$ & $\begin{array}{r}12 \\
13 \\
9 \\
10 \\
9 \\
9 \\
11 \\
8 \\
8 \\
= \\
= \\
= \\
= \\
= \\
=\end{array}$ & $\begin{array}{r}4 \\
4 \\
4 \\
2 \\
1 \\
3 \\
3 \\
4 \\
3 \\
3 \\
3 \\
1 \\
2 \\
1 \\
1 \\
1 \\
-1 \\
1\end{array}$ & $\begin{array}{r}\overline{ } \\
\overline{-} \\
\overline{ } \\
\overline{ } \\
\overline{3} \\
4 \\
3 \\
3 \\
3 \\
0 \\
2 \\
-2 \\
2\end{array}$ \\
\hline & \multicolumn{6}{|c|}{ Tents Open } \\
\hline $\begin{aligned} 11 & : 30 \\
1 & : 30 \\
3 & : 30 \\
8 & : 30 \\
10 & : 30 \\
12 & : 30 \\
1 & : 30 \\
2 & : 30 \\
3 & : 30\end{aligned}$ & $\begin{array}{l}3 \\
4 \\
2 \\
2 \\
3 \\
= \\
= \\
=\end{array}$ & $\begin{array}{l}0 \\
1 \\
0 \\
1 \\
1 \\
1 \\
0 \\
0 \\
0\end{array}$ & $\begin{array}{l}\overline{-} \\
\overline{-} \\
\overline{0} \\
1 \\
0 \\
0\end{array}$ & $\begin{array}{l}34 \\
28 \\
15 \\
21 \\
26 \\
= \\
= \\
=\end{array}$ & $\begin{array}{r}12 \\
9 \\
5 \\
5 \\
6 \\
7 \\
6 \\
6 \\
1\end{array}$ & $\begin{array}{l}= \\
= \\
5 \\
5 \\
5\end{array}$ \\
\hline
\end{tabular}


ACKNOMLWDGUNS 
This research was made possible through a fellowshlp grant from

The Iniveralty of Louiaville Institute of Industrial Research as portion of contracted research with

The offlce of The quartermaster General

Military Planning Division

Research and Development Brench 
VITA 
The author of this thesis, Barl Robert Corhard, wes born August 9,1922 , In Loulsville, Kentucky, the son of Edwin Leonard Gerhard and Lillian Just Cerhard. He attended grade school and then Saint Xavier High School in Loulsville, from which he graduated in 1940. He entered the Speed Selentific Sehool of the University of Loulsville in September 1940 and received his Bechelor of Chemlcel Engineering degree in September 1943. Th1s period included six months of co-operative work at the ColgatePalmolive-Peet Company in Jeffersonvilie, Indiane. He was elected to the honorary engineering fraternity of SIgma Tau and the honorary fraternity of Ph1 Kappa PhI.

Upon completion of his bachelor work he was employed by the Shell ofl Company as a juntor technologist in thetr Norco, Loutsiana, refinery where he worked for eight months. He entered the amed services in July 1944 and served for two years, including one year in the Asiaticpectific Theater.

Subsequent to his discharge from the andy he entered the graduate school of the Iniversity of Loulsvilie and received his Master of Chentcal Entineering degree in December 1947. His master work Included a fellowship in the Institute of Industrial Research, University of Loulsville, where he worked on the project, "Improved Design of Tents and Tentage kater1als", sponsored by the Research and Development branch of the office of quarternaster General. 